\title{
Antioxidánsok szerepe a levelek akklimációjában - rövidtávú alkalmazkodás változó megvilágításhoz
}

\author{
Ph.D. értekezés
}

\section{Majer Petra}

\author{
Témavezető: Dr. Hideg Éva
}

\begin{abstract}
MTA Szegedi Biológiai Kutatóközpont Növénybiológiai Intézet
SZTE TTIK Biológia Doktori Iskola
\end{abstract}

Szeged

2013 


\section{Tartalomjegyzék}

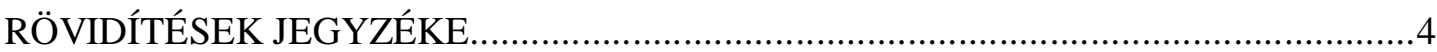

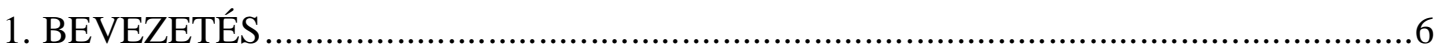

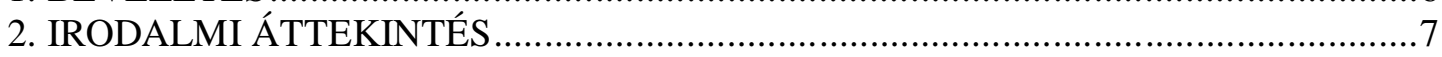

2.1. A növények és az abiotikus környezet - stresszválasztól az akklimatizációig...........7

2.2. Reaktív oxigénszármazékok és oxidatív stressz növényi rendszerekben....................8

2.3. A növényi antioxidáns rendszer .......................................................................11

2.3.1. Az enzimatikus antioxidáns rendszer és komponensei....................................11

2.3.2. Nemenzimatikus antioxidánsok ................................................................13

2.4. Fotoszintézis változó fényviszonyok között ........................................................15

2.4.1. Fotoinhibíció: a látható fény mint stresszor ...................................................15

2.4.2. A magas fényintenzitásra adott növényi válaszok ………………………….......16

2.4.3. Az UV-sugárzás hatásai a növényekre …………………............................18

2.5. Stressztolerancia és a redox homeosztázis ...........................................................19

2.6. Mérések a növényi prooxidáns/antioxidáns rendszer állapotának meghatározására 22

2.6.1. Teljes antioxidáns kapacitás (TAC) paraméterek …………………………......23

2.6.2. Specifikus antioxidáns kapacitás (SAC) mérések ..............................................25

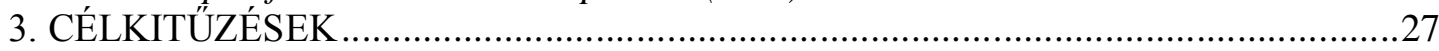

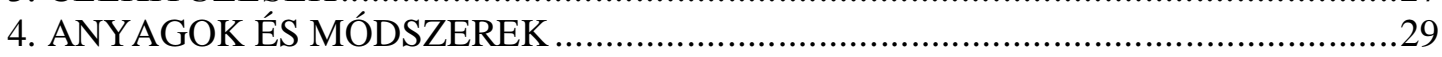

4.1. Növénynevelés és kezelések ...........................................................................29

4.1.1. A levelek antioxidáns-tartalma és fiziológiai állapota közti összefüggések vizsgálatára használt dohányok nevelési kërülményei............................................29

4.1.2. Szölő üvegházi nevelési körülményei és az UV-kezelés....................................29

4.1.3. A magas fényintenzitású előkezelés UV-akklimációban játszott szerepének vizsgálatára használt dohányok nevelése és a UV-kezelés körülményei.....................30

4.1.4. A szabadföldön nött hársfa növekedési körülményei és a levelek begyüjtése....31

4.2. Fotoszintézismérés gázcsere-analizátor segítségével...............................................31

4.3. Fotokémiai jellemzők meghatározása klorofill fluoreszcencia méréssel ...................31

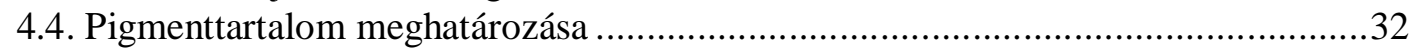

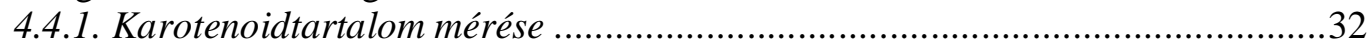

4.4.1. UV-B abszorbeáló pigmentek meghatározása …………………………….......33

4.5. Teljes antioxidáns kapacitás paraméterek meghatározása............................................33

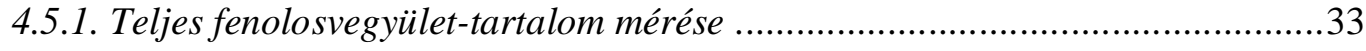

4.5.2. Trolox ekvivalens antioxidáns kapacitás teszt ……………………………......33

4.5.3. Vasion-redukáló képesség teszt ...................................................................3

4.6. Specifikus antioxidáns kapacitás paraméterek meghatározása...................................34

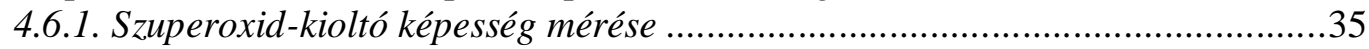

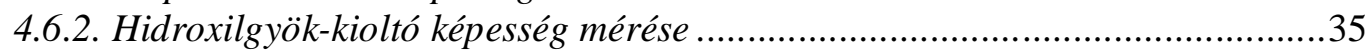

4.6.3. Szinglett oxigén kioltó képesség mérése …………………………………......36

4.7. Hárslevél-kivonatok és flavonolok abszorpciós spektrumának felvétele...................37

4.8. Hárslevelek flavonol aglükon tartalmának meghatározása ........................................37

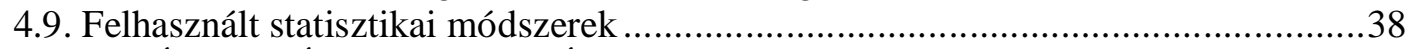

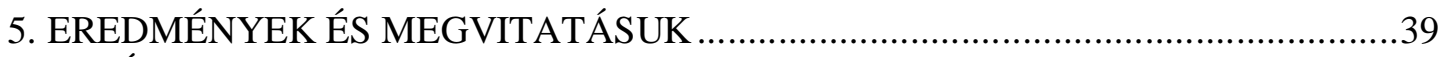

5.1. Általános és ROS-specifikus antioxidáns kapacitás próbák alkalmazhatósága a levelek fiziológiai állapotának leírására .......................................................................39

5.2. Eltérő antioxidáns-tartalmú fiatalabb és idősebb levelek akklimációs válaszai kiegészítő UV-sugárzásra üvegházi kísérletben ..........................................................43 
5.3. Magas fény előkezeléssel kiváltott eltérő antioxidáns-tartalommal rendelkező levelek UV-akklimációja üvegházi kísérletekben ... . .49

5.4. Különböző napfényviszonyokhoz alkalmazkodott levelek fényakklimációja és a

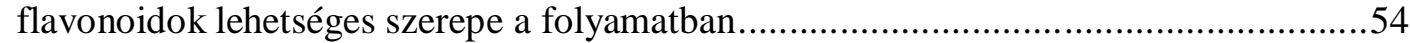

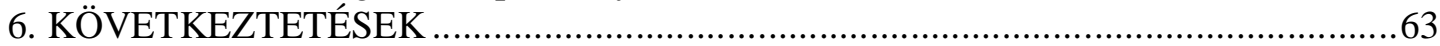

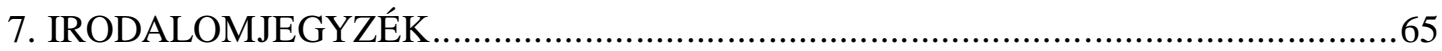

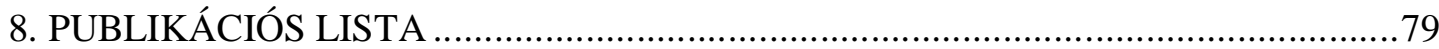

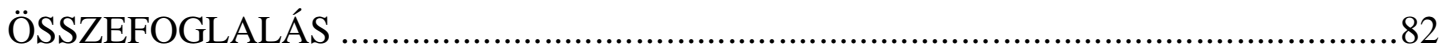

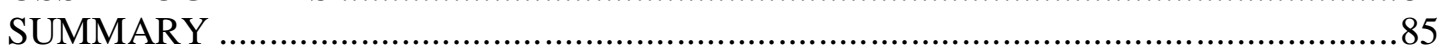






\section{RÖVIDÍTÉSEK JEGYZÉKE}

\begin{tabular}{|c|c|}
\hline AsA & $\begin{array}{l}\text { aszkorbát (aszkorbinsav anionja) } \\
\text { (ascorbic acid) }\end{array}$ \\
\hline APX & aszkorbát-peroxidáz \\
\hline BED & $\begin{array}{l}\text { biológiailag effektív UV dózis } \\
\text { (biologically effective UV dose) }\end{array}$ \\
\hline BSWF & $\begin{array}{l}\text { fényspektrum biológiai súlyozására szolgáló függvény } \\
\text { (biological spectral weighting function) }\end{array}$ \\
\hline CAT & kataláz \\
\hline DHAR & dehidroaszkorbát-reduktáz \\
\hline ER & endoplazmatikus retikulum \\
\hline ET & elektrontranszfer \\
\hline FC & Folin-Ciocalteu reagens \\
\hline $\mathrm{Fd}$ & ferredoxin \\
\hline FRAP & $\begin{array}{l}\text { vasion-redukáló képesség } \\
\text { (ferric ion reducing antioxidant power) }\end{array}$ \\
\hline GSH & glutation (redukált forma) \\
\hline GPX & glutation-peroxidáz \\
\hline GR & glutation-reduktáz \\
\hline GSSH & glutation-diszulfid (oxidált forma) \\
\hline GST & glutathion-S-transzferáz \\
\hline HAT & hidrogénatom-transzfer \\
\hline $\mathrm{IC}_{50}$ & $\begin{array}{l}\text { a reakciót 50\%-ban gátló koncentráció } \\
\text { (half inhibition concentration) }\end{array}$ \\
\hline MDHAR & monodehidroaszkorbát-reduktáz \\
\hline NADP & nikotinamid-adenin-dinukleotid-foszfát (oxidált forma) \\
\hline NADPH & nikotinamid-adenin-dinukleotid-foszfát (redukált forma) \\
\hline NPQ & $\begin{array}{l}\text { nem-fotokémiai kioltás } \\
\text { (non-photochemical quenching) }\end{array}$ \\
\hline PAR & $\begin{array}{l}\text { fotoszintetikusan aktív sugárzás } \\
\text { (photosynthetically active radiation) }\end{array}$ \\
\hline
\end{tabular}


PS

ROS

SAC

SOD

TAC

TEAC

TFT

UV fotokémiai rendszer

(photosystem)

reaktív oxigénszármazékok

ROS-specifikus antioxidáns kapacitás

szuperoxid-dizmutáz

teljes antioxidáns kapacitás

Trolox ekvivalens antioxidáns kapacitás

(Trolox equivalent antioxidant capacity)

teljes fenolosvegyület-tartalom

ultraibolya (hullámhossz)

(ultraviolet) 


\section{BEVEZETÉS}

„Bizony, a jóság és rosszaság, az irgalom és kegyetlenség ilyen furcsa viszonyban állanak egymással. Elválaszthatatlanul együtt müködnek, az egyik el se képzelhető a másik nélkül, akárcsak az, hogy valaki, akinek kitünő a szeme, ne lássa meg egyformán a kéket és vöröst, a pillangót és gilisztát. Ellentétek, az igaz, két ellensarki vég, de mindig természetes kölcsönhatásban vannak, a körülmények szerint váltakoznak, egymás nevét veszik föl, keringenek, átalakulnak, mint a pozitív és negatív villamosáram.”

Kosztolányi Dezső (1927) szavaival így foglalhatnánk össze azt az álláspontot, ahova a reaktív oxigénszármazékok (ROS) tanulmányozása óta mára eljutott a (növény)biológia. A ROS-okat sokáig elsősorban káros molekuláknak tekintették, amik kedvezőtlen körülmények vagy fertőzés hatására láncreakciószerüen továbbterjednek a növényi sejtben, miközben a sejtalkotók, membránok és a DNS degradációjához vezetnek. Ezzel szemben az antioxidánsok - azok az enzimek és vegyületek, amelyek az oxidatív formákat semlegesíteni képesek - mint jótékony szereplők voltak elkönyvelve a szervezetek élettörténetében. De ahogy mára már látjuk, a ROS-ok és antioxidánsok viszonya a sejtben valójában finom egyensúlyi rendszert alkot, a redox homeosztázist, amely folyamatos szabályozás alatt tartja a sejt anyagcsere- és fejlődési folyamatait, és a változó környezeti feltételekhez való alkalmazkodás kulcsa.

A növények alkalmazkodása a fluktuáló környezeti viszonyokhoz elsősorban a fotoszintetikus kapacitásuk megőrzésén alapul, mivel az energiaátalakítási folyamatok telítődése esetén a feldolgozatlan fényenergia káros hatású lehet, fotoinhibícióhoz, a fotokémiai rendszer degradálódásához vezethet. Ebben a folyamatban kiemelt szerepet játszanak a ROS-ok, azonban a változó fényviszonyokhoz való akklimációs válaszok elindításában is ezeké a főszerep, a védelmi útvonalak, s főként az antioxidáns rendszer indukciójával.

Vizsgálatainkban azt tüztük ki célul, hogy elemezzük a levelek általános antioxidáns-tartalmának hatását a növények fényakklimációjában, elsősorban magas fényintenzitású látható fény és UV-B sugárzás esetén. 


\section{IRODALMI ÁTTEKINTÉS}

\subsection{A növények és az abiotikus környezet - stresszválasztól az akklimatizációig}

A növényi szervezetek változó környezeti hatások között élnek és nagyfokú alkalmazkodási képességgel rendelkeznek. Egy cserepes növényre ránézve a fiziológiában jártas ember azonnal sok mindent meg tud állapítani a környezetről, amelyben az adott faj természetes körülmények között élhet. Például egy apró termetü pozsgás kövirózsa húsos levelei árulkodnak vízraktározó képességéről, s így arról, hogy csapadékkal csak időszakosan ellátott területről származik, levelei viaszos felülete pedig azt mutatja, hogy magas fényintenzitásokhoz, tüző naphoz alkalmazkodott. S ha egy kaktuszfajra vagy egy őserdei fán élő broméliafélére tekintünk, ezek a jellegzetességek a szélsőséges klímaviszonyok vagy életmód miatt még inkább szembetűnőek. Ezek a növényfaj egyedeire egységesen jellemző, főképp morfológiai jegyek a hosszútávú, generációkon át megvalósuló alkalmazkodás, az adaptáció jegyei, amelyek erős genetikai meghatározottsággal rendelkeznek. Azonban az egyes növényegyedek kiszakítva természetes környezetükből bizonyos - olykor egészen jelentős - mértékben képesek alkalmazkodni az adott környezeti viszonyokhoz, föképp biokémiai, s részben anatómiai, illetve morfológiai szinten: ezt a fajta alkalmazkodást akklimatizációnak nevezzük (Lichtenthaler 1998; Gaspar és mtsai. 2002). Erre a növénynek természetes környezetében is szüksége van, ahol a fény- és hőmérsékletviszonyok igen gyorsan fluktuálhatnak, míg például a szervesanyag-, vízellátottsági és egyéb körülmények lassabban váltakoznak. Az egyes szakirodalmakban ezeken kívül használt akklimáció kifejezést az egyféle környezeti változóhoz való alkalmazkodás jelölésére vezették be.

Az alkalmazkodás előidézője mindig az optimálistól eltérő környezeti viszony, ami a növényi szervezetben stresszorként jelenik meg (Lichtenthaler 1998). A stressz a szervezetnek a stresszorra adott nem specifikus szindrómában (tünetcsoportban) megnyilvánuló állapotát jelenti Selye János eredetileg orvosi biológiai meghatározása alapján. Így a növényi szervezet rövid- vagy hosszútávú, egyed- vagy populációszintü alkalmazkodása (akklimációja illetve adaptációja) a stresszre adott válaszreakció. Hagyományos felosztás szerint elkülöníthetünk abiotikus és biotikus stressztényezőket (Levitt 1972). Az előbbi csoportba sorolhatók a fény-, hőmérséklet- és vízviszonyok optimálistól eltérő változásai vagy a különböző tápanyagok és vegyi anyagok előfordulása (vagy hiánya) a növény környezetében, az utóbbiak közé pedig a kórokozók, kártevők 
hatása. Ezek a különböző hatások, illetve kombinációik eltérő válaszreakciókat váltanak ki a növényekből, mégis legtöbbüknél van egy közös, általánosan megfigyelhető jelenség: a sejtek redoxegyensúlyának eltolódása, ami sejtszinten jellemzően oxidatív stresszként nyilvánul meg (Mittler 2002).

Ennek oka, hogy a stresszorok megjelenése az erőforrások átcsoportosítását kívánja meg, így azok korlátozhatják a növényt életfolyamataiban, fotoszintetikus aktivitásában. Mivel a zöld növényi részek a fényenergia begyüjtésére optimalizálódtak, amennyiben az abszorbeált fényenergiát nem képesek fotokémiai reakcióikban hasznosítani, a többletenergiát a védekező rendszerük segítségével életfolyamataikat nem veszélyeztető módon kell elvezetniük. Stresszorok jelenlétében azonban az energiakompartmentalizáció reaktív oxigénszármazékok (ROS) fokozott termelődéséhez vezethet.

\subsection{Reaktív oxigénszármazékok és oxidatív stressz növényi rendszerekben}

A reaktív oxigénszármazékok az aerob légzés és a fotoszintézis természetes velejárói, így a növényi metabolizmus elkerülhetetlen melléktermékei. A molekuláris oxigén erős oxidálószer, amelynek teljes redukciója ( 4 e és $4 \mathrm{H}^{+}$átadásával) vízmolekula $\left(\mathrm{H}_{2} \mathrm{O}\right)$ képződéséhez vezet, azonban részleges redukciós állapotai reaktív intermedierek létrejöttét eredményezik. Az oxigénből elektronátadással szuperoxidgyök-anion $\left(\mathrm{O}_{2}{ }^{*}\right)$, illetve hidrogén-peroxid $\left(\mathrm{H}_{2} \mathrm{O}_{2}\right)$ és hidroxilgyök ( $\left.{ }^{\circ} \mathrm{OH}\right)$ keletkezhet. Más úton, energiaátadással is keletkezhet ROS molekuláris oxigénből, ami ennek hatására triplett $\left({ }^{3} \Delta \mathrm{gO}_{2}\right)$ állapotból a sokkal reaktívabb szinglett $\left({ }^{1} \Delta \mathrm{gO}_{2}\right.$, a továbbiakban $\left.{ }^{1} \mathrm{O}_{2}\right)$ állapotba kerül.

Oxigén a fotoszintetikus vízbontás termékeként, illetve a gázcserenyílásokon keresztül beáramolva mindig jelen van a kloroplasztiszok tilakoidmembránjának környezetében, ahol a fotoszintetikus elektrontranszportlánc is elhelyezkedik (1. ábra). A tilakoidokba ágyazott két fotokémiai rendszeren (photosystem, PS) keresztül a fényenergia kémiai energiává alakul át, miközben az elektronok donorok és akceptorok sorozatán keresztülhaladva végül a nikotinamid-adenin-dinukleotid-foszfát $\left(\mathrm{NADP}^{+}\right)$redukálására (NADPH), illetve a víz oxidálására használódnak fel. Emelett a fényenergia protonmozgató erőt is generál a membrán két oldala között, ami adenozin-trifoszfát szintéziséhez vezet. A PS I elektronsztranszport-láncának túltelítődésekor a ferredoxin (Fd) elektronja átadódhat a közelben lévő $\mathrm{O}_{2}$ molekuláknak, ami $\mathrm{O}_{2}{ }^{*-}$ keletkezéséhez vezethet a Mehler-reakción keresztül (Mehler 1951). A PS II e-akceptorainak (feofitin, $\mathrm{Q}_{A}, \mathrm{Q}_{\mathrm{B}}, \mathrm{PQ}$ ) 
autooxidációja is eredményezheti az oxigén redukcióját, de az általánosan elfogadott nézet szerint a szuperoxidgyök keletkezésének elsődleges helye a PS I (Asada 1999; Asada 2006). Ezen kívül a PS II donor oldalán a víz részleges oxidációja $\mathrm{H}_{2} \mathrm{O}_{2}$ képződéséhez vezethet, illetve az elektrontranszport-láncban keletkezett $\mathrm{O}_{2}{ }^{--}$további redukciója is vezethet $\mathrm{H}_{2} \mathrm{O}_{2}$ megjelenéséhez, ami tovább alakulhat hidroxilgyökké a Fenton-reakció során (1. pl. Pospíšil 2009 összefoglalóját). A másik fontos ROS-képződési módnál a PS II triplett állapotú reakcióközpont klorofilljáról $\left({ }^{3} \mathrm{P} 680^{*}\right)$ energiaátadással ${ }^{1} \mathrm{O}_{2}$ keletkezik (Vass és mtsai. 1992). A potenciális ROS-keletkezési helyeket a kloroplasztiszmembrán fotokémia reakciósorozatában az 1. ábra illusztrálja.

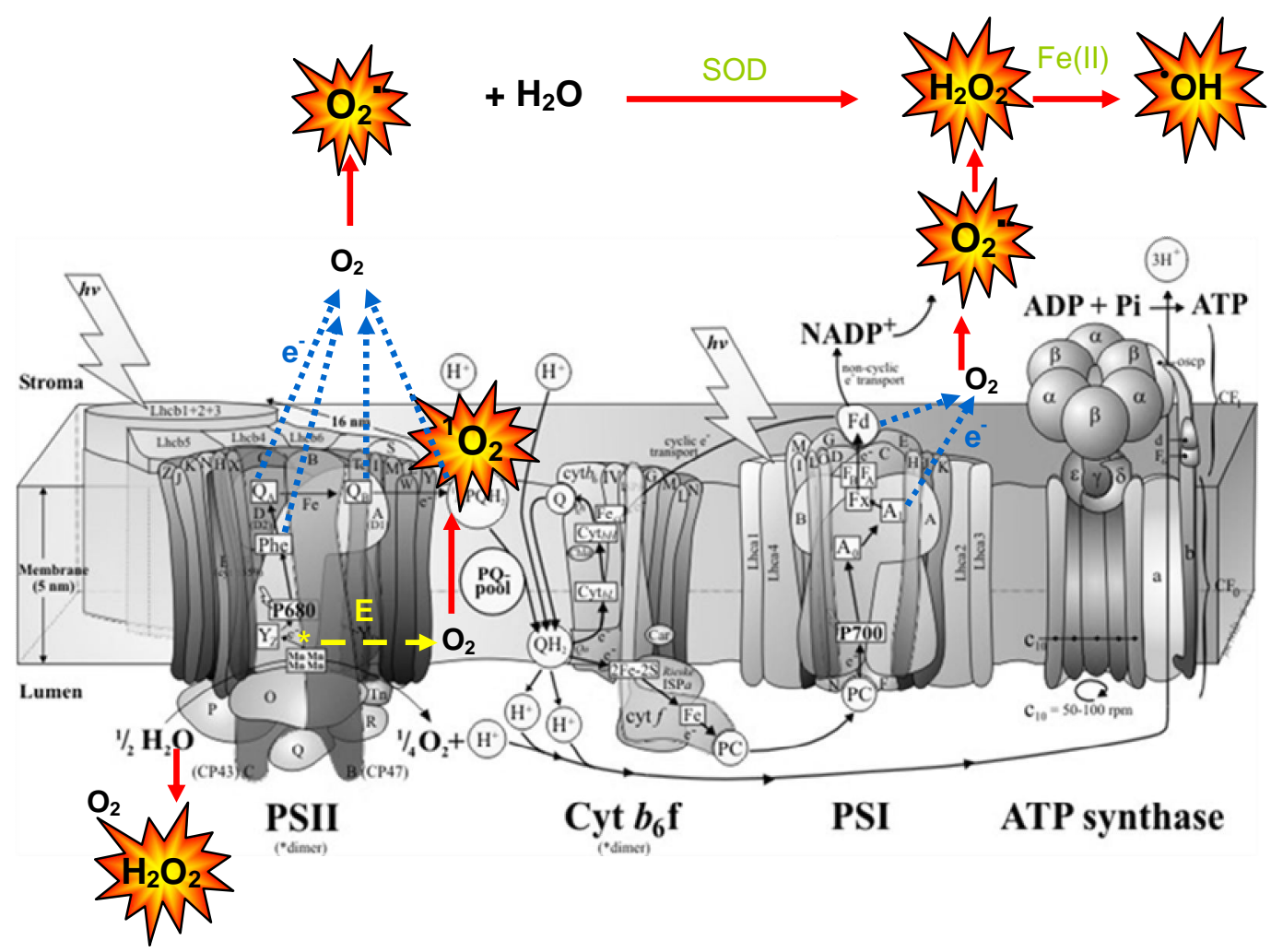

1. ábra: Potenciális ROS keletkezési helyek a kloroplasztisz tilakoidmembránjába ágyazott fehérjekomplexek fotoszintetikus elektrontranszport-útvonalában. A kék pontozott nyilak az elektron- $\left(\mathrm{e}^{-}\right)$ átadások irányát jelzik, míg a sárga szagatott vonal az energia (E) átadásának irányát mutatja. A PS II donor oldalán a víz oxidációja hidrogén-peroxid $\left(\mathrm{H}_{2} \mathrm{O}_{2}\right)$ kialakulásához vezethet; a PS II akceptor oldalán a feofitin (Phe), a kinonmolekulák $\left(\mathrm{Q}_{\mathrm{A}}, \mathrm{Q}_{\mathrm{B}}\right)$, vagy a plasztokinon $(\mathrm{PQ})$ oxidációja vezethet szuperoxidgyök $\left(\mathrm{O}_{2}{ }^{\circ}\right)$ képződéséhez; a PS I akceptorai, az $\mathrm{A}_{1}$, illetve a ferredoxin $(\mathrm{Fd})$ oxidációja $\mathrm{O}_{2}{ }^{\circ}$ - képződését eredményezheti; a triplett állapotú P680 klorofillról energiaátadással ${ }^{1} \mathrm{O}_{2}$ keletkezhet. $\mathrm{A} \mathrm{O}_{2}{ }^{*-}$ spontán módon vagy szuperoxiddizmutáz enzim közremüködésével $\mathrm{H}_{2} \mathrm{O}_{2}$-dá alakulhat, ami Fe(II) molekula segítségével Fenton-reakcióban hidroxilgyököt ( $\mathrm{OH})$ képezhet. Az eredeti ábra forrása: Dr. Jon Nield, (C) Wolfson Laboratories, Department of Biological Sciences, Imperial College London, 2003. 
A leírt gyökös $\left(\mathrm{O}_{2}{ }^{-},{ }^{\circ} \mathrm{OH}\right)$, illetve nemgyökös $\left(\mathrm{H}_{2} \mathrm{O}_{2},{ }^{1} \mathrm{O}_{2}\right)$ természetü oxigénszármazékok közös jellemzője a rövid életidő és az erős reaktivitás, bár ezen tulajdonságaikban nagy eltérések találhatók közöttük (Halliwell és Gutteridge 1999). Ezek a reaktív oxigénformák képesek egymásba is átalakulni különböző utakon, enzimek segítségével (pl. szuperoxid-dizmutáz katalizált $\mathrm{O}_{2}{ }^{--} \rightarrow \mathrm{H}_{2} \mathrm{O}_{2}$ átalakulás) vagy spontán módon (pl. $\mathrm{O}_{2}{ }^{\bullet-} \rightarrow \mathrm{H}_{2} \mathrm{O}_{2}$ ), illetve kelációs fémek közremüködésével, például a Fentonreakció során ( $\left.\mathrm{Fe}(\mathrm{II})+\mathrm{H}_{2} \mathrm{O}_{2} \rightarrow \mathrm{Fe}(\mathrm{III})+{ }^{\circ} \mathrm{OH}+{ }^{-} \mathrm{OH}\right)$. A legreaktívabb a ROS-ok közül a hidroxilgyök (Møller és mtsai. 2007). Terjedésüket viszont rövid életidejük korlátozza: még a nagy in vitro stabilitású $\mathrm{H}_{2} \mathrm{O}_{2}$ is csak néhány mikrométeres távolságra tud eljutni az élő szervezetben (Halliwell és Gutteridge 1999). Viszont a ROS-ok könnyen reakcióba lépnek a sejt különböző vegyületeivel, a fehérjékkel, a membránnal (lipidperoxidáció) és egyéb sejtalkotókkal, amelynek eredményeképpen az elsődleges ROS keletkezési helyektől távolabbi sejtrészekben is további gyökös természetü anyagok keletkeznek, mint a peroxilgyök $\left(\mathrm{ROO}^{\circ}\right)$, alkoxilgyök $\left(\mathrm{RO}^{\circ}\right)$ vagy a hidroperoxilgyök $\left(\mathrm{HOO}^{\circ}\right)$. Mindezek a reaktív formák láncreakciószerüen továbbterjedve oxidatív stressz kialakulásához vezethetnek (Mittler 2002; Halliwell 2006). A folyamatban szerepet játszanak a nitrogénmonoxid (NO) szabadgyökök, illetve a NO és ROS-ok reakciójából keletkező reaktív nitrogénszármazékok is, mint például a $\mathrm{NO}$ és $\mathrm{O}_{2}{ }^{\bullet-}$ reakciójából képződő peroxinitrit (OONO־) (Vandelle és Delledonne 2011). A membránlipid-peroxidáció és a sejtalkotók oxidációja végül a sejt halálához vezethet (Møller és mtsai. 2007).

A ROS-képződés több helyszínen is zajlik a növényekben, a kloroplasztisz mellett két jelentős keletkezési helyük a mitokondrium és a peroxiszóma. A mitokondriumban a légzési elektrontranszport-láncban résztvevő I-es és III-as komplex a $\mathrm{O}_{2}{ }^{\bullet-}$ keletkezésének fő színterei. A peroxiszómákban oxidatív típusú anyagcserefolyamataik melléktermékeként jelenik meg a $\mathrm{O}_{2}{ }^{\circ}$, egyrészt a xantinnak a xantin-oxidáz által katalizált urinsavvá való alakulása során, másrészt membránjuk elektrontranszport-láncában. $\mathrm{H}_{2} \mathrm{O}_{2}$ is keletkezhet itt nagyobb mennyiségben, elsősorban a fotorespiráció során a glioxalát-oxidáz enzim müködésével, a zsírsavak $\beta$-oxidációjakor, vagy a flavin-oxidázok katalizálta reakcióban (del Rio és mtsai. 2006).

A három említett sejtorganellumban lezajló ROS-képződésen kívül egyéb (itt nem részletezett folyamatok) eredményeképpen szabályozott, katalitikus módon is keletkeznek a növényi sejt több részében ROS-ok, pl. az endoplazmatikus retikulumban (ER), a citoplazmában és az apoplasztban is (Mittler 2002; Apel és Hirt 2004; Gill és Tuteja 2010), amelyeknek szerepe lehet a patogének elleni védelemben, stresszválaszhoz kapcsolódó 
jelátviteli útvonalak indukálásában és más szabályozó folyamatokban is (1. pl. Apel és Hirt 2004, vagy Foyer és Noctor 2009 áttekintő tanulmányait).

Az, hogy a ROS-ok nem csak mint káros, sejtalkotókat oxidáló ágensek lépnek fel, és alkalmasak lehetnek jelátviteli szerepekre, védelmi útvonalak indukálására is, egy előfordulásukat és mennyiségüket több szinten szabályozó, többkomponensű antioxidánsrendszer müködésének köszönhető. Ez a rendszer a sejteket egyfajta egyensúlyi állapotban, az ún. redox homeosztázisban tartja (Halliwell 2006; Foyer és Noctor 2009). Erről a rendszerről és alkotóelemeiröl szól a következő fejezet.

\subsection{A növényi antioxidáns rendszer}

Antioxidáns minden vegyület, ami egy oxidálható szubsztrátnál alacsonyabb koncentrációban jelen léve képes jelentősen késleltetni vagy gátolni annak oxidációját (Halliwell és Gutteridge 1999). Egy adott antioxidáns gyökkioltó-képessége függ annak reaktivitásától és koncentrációjától, illetve sejten belüli előfordulásától. Az antioxidánsokat legáltalánosabban enzimekre és nemenzimatikus, alacsony molekulasúlyú vegyületekre oszthatjuk, bár valójában a két rendszert nem lehet élesen elválasztani egymástól, hisz több enzim kofaktorként használja az utóbbi csoport tagjait, más antioxidáns enzimek szerepe pedig épp ezen vegyületek regenerációjában van.

A ROS-ok közül a $\mathrm{O}_{2}{ }^{\cdot-}$ és a $\mathrm{H}_{2} \mathrm{O}_{2}$ elsősorban enzimek közremüködésével eliminálódik, míg a ${ }^{\circ} \mathrm{OH}$ és a ${ }^{1} \mathrm{O}_{2}$ semlegesítésére nem ismerünk enzimes reakciókat. Fontos megjegyezni azt is, hogy a ROS-képződés elkerülésére, illetve megelőzésére is számos mechanizmus ismert a növényekben, amelyekről a későbbiekben még szó esik.

\subsubsection{Az enzimatikus antioxidáns rendszer és komponensei}

A következőkben a legfontosabb antioxidáns enzimeket, sejten belüli lokalizációjukat, és a reakció termékét a célzott ROS alapján csoportosítva mutatom be.

A szuperoxidgyök elleni védelem első vonalát a szuperoxid-dizmutáz (SOD) metalloenzimek családja alkotja (Alscher és mtsai. 2002). A fém kofaktor szerint három fajtáját különböztetjük meg: $\mathrm{Cu} / \mathrm{ZnSOD}, \mathrm{MnSOD}$ és FeSOD. Ezek megtalálhatóak a kloroplasztiszban (Cu/ZnSOD és FeSOD), a mitokondriumban (MnSOD), a peroxiszómában (CuZnSOD és MnSOD), a glioxiszómákban, az apoplasztban (valószínüleg $\mathrm{Cu} / \mathrm{ZnSOD}$ ) és a citoszólban $(\mathrm{Cu} / \mathrm{ZnSOD})$ is, így minden olyan helyen 
lehetővé teszik a $\mathrm{O}_{2}{ }^{\bullet-}$ gyors eliminálását, ahol az megjelenhet. Közremüködésükkel a szuperoxid-gyökből $\mathrm{H}_{2} \mathrm{O}_{2}$ és $\mathrm{O}_{2}$ képződik. Érdemes megemlíteni, hogy két $\mathrm{O}_{2}{ }^{*}$ molekulából spontán módon is keletkezhetnek a fenti termékek, bár sokkal kisebb hatékonysággal, mint az enzimkatalizált reakcióban.

A hidrogén-peroxid, amely legnagyobb mennyiségben a SOD enzim müködése során keletkezik, különböző utakon keresztül kerülhet semlegesítésre, részben a keletkezés helyének függvényében. A kloroplasztiszban az aszkorbát-peroxidáz (APX) enzimek játszák a fő szerepet hatékony eliminációjában. Ezek az enzimek az aszkorbátot (AsA), az aszkorbinsav (C-vitamin) anionját használják kofaktorként a $\mathrm{H}_{2} \mathrm{O}_{2}$ vízzé történő redukciójához, miközben azt monodehidroaszkorbát-gyökké alakítják. A monodehidroaszkorbát újraredukálása egy komplex folyamat, amelyben olyan enzimek vesznek részt, mint a $\mathrm{NAD}(\mathrm{P}) \mathrm{H}$ kofaktorral müködő monodehidroaszkorbát-reduktáz (MDHAR), a glutation (GSH) kofaktorral müködő dehidroaszkorbát-reduktáz (DHAR), illetve a szintén NADPH kofaktorral müködő glutation-reduktáz (GR). Ezeknek az enzimeknek és kofatoraiknak együttmüködése alkotja az aszkorbát-glutation ciklust, amely a kloroplasztiszok fó antioxidáns védekezési rendszere (Asada 1999). Ezen kívül a citoplazmában, a mitokondriumokban, glioxiszómákban és a peroxiszómákban is találhatók APX enzimek.

A katalázok (CAT) vastartalmú enzimek, amelyek a $\mathrm{H}_{2} \mathrm{O}_{2}$ vízzé és oxigénné való átalakítását katalizálják. A peroxiszómákban képződő $\mathrm{H}_{2} \mathrm{O}_{2}$ semlegesítésében van meghatározó szerepük. A glutation-peroxidázok (GPX) a $\mathrm{H}_{2} \mathrm{O}_{2}$ mellett szerves és lipid hidroperoxidok redukcióját is katalizálják és GSH-t (vagy tioredoxint) használnak elektrondonorként. A sejten belül több helyen is megtalálhatóak (kloroplasztisz, mitokondrium, citoplazma, ER). A fentieken kívül számos peroxidáz hatású enzim ismert még, változatos sejten belüli lokalizációval, amelyeknek a $\mathrm{H}_{2} \mathrm{O}_{2}$ redukciójának katalizálása csak egy, a sok fontos funkciójuk közül (Veitch 2004).

A felsoroltakon kívül még számos enzim vesz részt közvetett módon a ROS elleni védelemben, ilyenek a glutation-S-transzferázok (GST), amelyek a citotoxikus vegyületeket glutationhoz kötik, ezzel megjelölve őket a membránon át történő elszállításhoz, vagy a peroxidáz aktivitással rendelkező peroxiredoxinok (Dietz és mtsai. 2006) illetve az ezeket redukáló tioredoxinok (Lemaire és mtsai. 2007); ezek részletes bemutatása túlmutat e disszertáció témakörén. 


\subsubsection{Nemenzimatikus antioxidánsok}

Ahogy azt már említettük, két nagyon fontos ROS, a ${ }^{\circ} \mathrm{OH}$ és a ${ }^{1} \mathrm{O}_{2}$ semlegesítésére alkalmas enzimek nem ismertek, így ezek detoxifikálása csak a nemenzimatikus antioxidánsok révén valósulhat meg. $\mathrm{Az}{ }^{\circ} \mathrm{OH}$ semlegesítéséért elsősorban a aszkorbát, a tokoferolok és a glutation felelősek, de csak amennyiben a keletkezés helyéhez közel vannak jelen, hisz ez a legnagyobb reaktivitású a ROS formák közül. Valójában in vivo körülmények között a ${ }^{\circ} \mathrm{OH}$ hidrogén-peroxidból való kialakulásának elkerülése jelentősebb védekezési forma lehet, ami a Fenton-reakciót katalizáló fémek kelációjával valósulhat meg. A ${ }^{1} \mathrm{O}_{2}$ keletkezését elsősorban a triplett állapotú klorofill képződésének megakadályozásával lehet elkerülni. A karotenoidok, a tokoferolok és az aszkorbát (illetve a plasztokinon) is részt vehet a szinglett oxigén energiájának kioltásában a kloroplasztiszban, ahol ez a ROS megjelenik (Triantaphylidès és Havaux 2009).

A glutation és az aszkorbát a legfontosabb és legtöbbet tanulmányozott antioxidáns hatású vegyületek (Noctor és Foyer 1998; Smirnoff 2000; Foyer és Noctor 2011; Noctor és mtsai. 2012). Szerepükről már az enzimatikus védekezésnél volt szó, hisz ezek a molekulák a kulcsfontosságú víz-víz ciklusban szereplő antioxidáns enzimek kofaktorai (Asada 1999). Azonban mindkét vegyület önmagában is hatékony vízoldékony antioxidáns (Foyer és Noctor 2011). A GSH egy tripeptid, amelynek jelentősége cisztein aminosavának tiol (-SH) csoportjában rejlik. Ennek segítségével a GSH redukáló ágensként tud szolgálni diszulfid-híddal rendelkező vegyületek számára, miközben két molekulája glutationdiszulfiddá (GSSG) oxidálódik. Az újraredukálást a glutation-reduktáz (GR) enzim végzi NADPH közremüködésével, nagy hatékonysággal. A GSH:GSSG arány szabályozása a növényi sejtek redox állapotának egyik legfontosabb komponense és egyben az oxidatív stresszt jelző paramétere is (Noctor és mtsai. 2012). Az AsA hasonló szerepet tölt be, és egészséges növényi szövetekben, stresszmentes állapotokban oxidált formája csupán nyomokban van jelen (Foyer és Noctor 2011). Egyik oxidált formája a már említett monodehidroaszkorbát, melynek két molekulája spontán módon aszkorbátra és dehidroaszkorbátra bomolhat. Az aszkorbát regenerálását a ferredoxin, vagy a MDHAR és DHAR enzimek végzik, NADPH mint kofaktor közremüködésével. Az AsA ezen kívül más antioxidánsok regenerációjában is szerepet játszik, például az $\alpha$-tokoferoléban.

A B6-vitamin - ami hat különböző, egymásba átalakulni képes vízoldékony vegyület csoportját jelenti - ${ }^{1} \mathrm{O}_{2}$ és $\mathrm{O}_{2}{ }^{--}$semlegesítésére is képes (Bilski és mtsai. 2000; 
Denslow és mtsai. 2005). Csak újabban sikerült kimutatni a piridoxin ${ }^{1} \mathrm{O}_{2}$-kioltó szerepét in vivo is, B6-deficiens növények segítségével (Havaux és mtsai. 2009).

A karotenoidok lipidoldékony vegyületek, amelyek elsősorban mint fotoszintetikus fénybegyüjtő pigmentek ismertek. Két fő csoportjukat a karotinok és a xantofillok képezik. Az utóbbiak közé tartoznak a xantofill ciklusból ismert violaxantin, anteraxantin és zeaxantin, amelyek sorozatos egymásba való átalakulását a violaxantin-deepoxidáz, illetve violaxantin-epoxidáz enzimek végzik a fényviszonyoknak megfelelően (Demmig-Adams és Adams 1993). A kloroplasztiszokban a fotokémiai rendszerek védelmében játszanak szerepet, egyrészt a triplett klorofillok többletenergiájának átvételével és hő formájában történő leadásával, másrészt a már keletkezett ${ }^{1} \mathrm{O}_{2}$ semlegesítésével (Triantaphylidès és Havaux 2009). In vitro kísérletekben kimutatták más, gyökös természetü ROS-ok semlegesítésére való alkalmasságukat is (Miller és mtsai. 1996), azonban ennek növényélettani jelentőségét in vivo körülmények között nem ismerjük.

A tokoferolok (E-vitaminok) szintén lipidoldékony membránlokalizált antioxidánsok, lipidperoxilgyökök és ${ }^{1} \mathrm{O}_{2}$ semlegesítésére alkalmas vegyületek, így elsősorban lipidperoxidáció-gátlókként ismeretesek, bár emellett élettani szerepük is van, például a membrán stabilizálásában (Munné-Bosch 2007). A tokoferol regenerációja antioxidáns müködése során képződő gyökös formájából az AsA segítségével történik.

A fenolos vegyületek a növények másodlagos anyagcseretermékei, aromás gyürüvel és egy vagy több hidroxilcsoporttal rendelkeznek. ROS-semlegesítő és fémkelátor hatású vegyületek, amelyek föképpen az oxidációs láncreakció megtörésében játszanak szerepet. A keletkező fenoxilgyök-intermedierek viszonylag stabilak, így újabb láncreakció nehezen indul el, illetve képesek a láncreakció terminációjára is (összefoglaló munka Dai és Mumper 2010). Az ebbe a csoportba tartozó, szerkezetileg különböző kb. 810 ezer vegyület abban közös, hogy a fenilalaninból kiinduló anyagcsereúton keresztül termelődnek (fenil-propanoid útvonal). Szerepet játszanak az ultraibolya (UV) fény elleni védelemben, termések, virágok színének kialakításában és a növények kártevők elleni védekezésében is. A fenolos vegyületek közé tartoznak a fenolos savak, flavonoidok, tanninok, sztilbének és a lignánok.

A fenolos vegyületek legnagyobb és legjelentősebb csoportját a flavonoidok alkotják. A flavonoidok flavánvázas vegyületek, amelyek szerkezetük szerint három gyürübe (C6-C3-C6) rendeződnek. A központi gyürü oxidációs állapota alapján hat alcsoportba oszthatók: flavonok, flavonolok, flavanolok, flavanonok, izoflavonok, és antocianinok. A flavonoidok a növényekben föként glükozilált formában vannak jelen és 
elsősorban a mezofill sejtek vakuólumában halmozódnak fel, de a kloroplasztiszbeli lokalizációjukat, illetve szintézisüket megerősítő eredmények is vannak (Saunders és McClure 1976; Agati és mtsai. 2007; Zaprometov és Nicolaeva 2003). A vegyületcsoport in vitro antioxidáns hatását számos tanulmányban kimutatták (Ratty és Das 1988; Tournaire és mtsai. 1993; Rice-Evans és mtsai. 1995), azonban élö szövetekben játszott gyökfogó szerepük jelentőségéről megoszlanak a vélemények (Hernández és mtsai. 2009).

A fentieken kívül még számos olyan vegyületet találunk a növényi sejtekben, amiknek antioxidáns hatása in vitro körülmények között bizonyított, de jelentőségük a növényi sejtekben elsősorban más funkcióiknak köszönhető, ilyenek például a poliaminok, a cukrok és a prolin.

\subsection{Fotoszintézis változó fényviszonyok között}

\subsubsection{Fotoinhibíció: a látható fény mint stresszor}

A növényélettani kutatók a XIX. század végén fedezték fel, hogy a fotoszintetikus aktivitás fényfüggése telítési görbét mutat, vagyis egy pont után a fotoszintetikusan aktív fény (photosynthetically active radiation, PAR) intenzitásának növekedése már nem növeli tovább a $\mathrm{CO}_{2}$-megkötést, sőt, aktivitáscsökkenést eredményez (Ewart 1896, 1. Adir és mtsai. 2003 történeti visszatekintését). A fotoinhibíció a fotoszintézis fény általi gátlása, a fotoszintetikus apparátus oxidatív károsodásán keresztül.

Azóta a fotoinhibíció jelenségét, fiziológiai körülményeit, molekuláris mechanizmusait számos kutató tanulmányozta (Powles 1984; Aro és mtsai. 1993; Vass és mtsai. 1992; Keren és mtsai. 1997). A ma általánosan elfogadott nézet szerint a PS II érzékenyebb a fotoinhibícióra, mint a PS I (Keren és Krieger-Liszkay 2011). A fotoinhibíció különböző, a szakirodalomban megtalálható mechanizmusainak (1. pl. Keren és Krieger-Liszkay 2011 összefoglalóját) közös jellemzője a ROS formák, nevezetesen a ${ }^{1} \mathrm{O}_{2}, \mathrm{O}_{2}{ }^{\circ}, \mathrm{H}_{2} \mathrm{O}_{2}$ és ${ }^{\circ} \mathrm{OH}$ fokozott képződése (a már bemutatott útvonalakon, 1. 1. ábra). A ROS-ok keletkezése a PS II károsodásához vezet, valószínűleg közvetlen módon (Song és mtsai. 2006; Krieger-Liszkay és mtsai. 2011). A PS II javító mechanizmusai ugyan gyorsan és hatékonyan müködnek (főképp a D1 protein cseréje által, Aro és mtsai. 1993), de amennyiben a károsodás mértéke meghaladja a javítómechanizmusok kapacitását, a fotoinhibíció eredményeképp a fotoszintetikus elektrontranszport hatékonysága jelentős mértékben lecsökkenhet. A ROS-ok pedig egyrészt a fotoszintézis további csökkenését 
okozzák, másrészt továbbterjedve megkezdhetik károsító láncreakcióikat, membrándegradációt, lipidperoxidációt, illetve a sejtalkotók bomlását okozva (oxidatív stressz). Ilyenkor az antioxidánsok normál (készenléti) szintje már nem tudja féken tartani a ROS-indukált károsodási folyamatokat.

\subsubsection{A magas fényintenzitásra adott növényi válaszok}

A fentiek szerint a feldolgozható (fotoszintézisre használható, illetve biztonságosan elvezethető) mennyiséget tartósan meghaladó PAR képes gátolni a fotoszintézist és ROS produkción keresztül oxidatív stresszt okozni. Ez az állapot mind magas fényintenztású megvilágítással, mind a metabolikus utak hatékonyságát csökkentő környezeti hatásokkal előidézhető gyakori stressz jelenség, aminek elkerülésére különböző stratégiák fejlődtek ki a növényekben.

A fotoszintézis rövidtávú akklimációja elsősorban molekuláris szinten zajlik le a fotoszintetikus apparátus elemi összetételének változásai révén, úgy mint a PS II/PS I, a citokróm $\mathrm{b}_{6} / \mathrm{f}$ komplex, a Calvin-ciklus enzimei, vagy a fénybegyüjtő komplexek arányainak változásai révén (Anderson és mtsai. 1995). A többlet abszorbeált energia átcsoportosítása alternatív fotokémiai folyamatokba (ciklikus elektrontranszport, fotoilletve klororespiráció), vagy szabályozott elvezetése megelőző védelmet jelenthet a ROS képződése ellen a fotoszintetikus rendszer számára (Niyogi 1999; Foyer és mtsai. 2009; Peltier és Cournac 2002).

Az abszorbeált fényenergia káros hatásai elleni védelem egyik legfontosabb eleme a többletenergia hő formájában történő leadása, vagyis a nemfotokémiai kioltás (nonphotochemical quenching, NPQ) (Bilger és Björkman 1990; Müller és mtsai. 2001). A mechanizmus elnevezése arra utal, hogy az NPQ folyamatokat a fluoreszcencia kioltása jelzi, annak csökkenésével lehet nyomon követni. Az abszorbeált fény szinglett állapotba gerjeszti a klorofillmolekulákat $\left({ }^{1} \mathrm{Ch} l^{*}\right)$, ami a következő utakon térhet vissza az alapállapotba: (1) fény (fluoreszcencia) kibocsátásával, (2) fotokémiai úton, vagy (3) fénysugárzás nélküli energiakibocsátással. További lehetőség a triplett gerjesztett állapotba történő átmenet, ami a ${ }^{1} \mathrm{O}_{2}$ lehetséges forrása. Mivel a fenti folyamatok egymással kompetitív módon jelentkeznek, a növények úgy tudják minimalizálni a ${ }^{3} \mathrm{Chl}{ }^{*}$ képződését, hogy a fotokémiai fényhasznosítást és a szabályozott energiadisszipációs folyamatokat magas hatékonysággal végzik, ezzel a fluoreszcencia minimális mértékü marad. Így a 
klorofill fluoreszcencia analízis segítségével információt nyerhetünk arról, hogy az elnyelt fény milyen arányban hasznosul a fotokémiai útvonalakon $\left(\mathrm{Y}_{\mathrm{PSII}}\right)$, illetve kerül alternatív utakra. Az össz-fluoreszcencia kibocsátás ugyan nagyon kicsi (az abszorbeált fényenergiának csupán 1-2\%-a), mégis jól követhető az emittált fény jellemző hullámhosszán történő méréssel (Kautsky és Hirsch 1931; Maxwell és Johnson 2000; Baker 2011). Bár ez a mérés csak relatív értékeket, arányokat tud adni, mégis számos információval szolgálhat a levél (és az egész növény) állapotáról, ami a fotoszintézis hatásfokát illeti.

A fel nem használt gerjesztési energia elvezetésének jellemzésére többféle paraméter használatos. Ezek közül a fentiekben leírt NPQ elsősorban a szabályozott hőleadást képviseli, ami a xantofill ciklus karotenoidjain keresztül valósul meg (DemmigAdams és Adams 1993). Ebben a folyamatban a túl magas fényintenzitást a sejtek a kloroplasztisz tilakoidmembránjának két oldala között megnövekedett pH-különbségen keresztül érzékelik, aminek hatására aktivizálódik a violaxantin zeaxantinná való átalakítását katalizáló deepoxidáz enzim (Ort 2001). Tehát az NPQ során a zeaxantin a kloroplasztiszban felhalmozódik, ha az abszorbeált fényenergia mennyisége meghaladja azt, amit a fotokémiai rendszerek hasznosítani tudnak, és segíti a többletenergia hő formájában való leadását.

Egy alternatív modell, melyet a dolgozatban szereplő fotokémiai mérési eredmények kiértékelésében használtunk, megkülönböztet szabályozott (tehát a fenti folyamatokat is magában foglaló) és szabályozatlan (a ROS képződéshez vezető utakat képviselö) kioltási folyamatokat, melyek hozamát Klughammer és Schreiber (2008) munkája alapján $\mathrm{Y}_{\mathrm{NPQ}}$, illetőleg és $\mathrm{Y}_{\mathrm{NO}}$ szimbólumokkal jelöljük. Ezek változó fluoreszcencia mérésekkel történő meghatározását az Anyagok és módszerek fejezet részletezi.

A preventív védekezési utak tanulmányozása tájékoztatást adhat a fotoszintézis változó fényhez történő akklimációjáról. Azonban ezen útvonalak müködése mellett is számolni kell a fokozott ROS-képződéssel. Így az akklimációs válaszok tanulmányozásának másik fontos része a ROS-semlegesítésnek, mint a védelem második vonalának tanulmányozása (Logan és mtsai. 2006). Ráadásul a ROS-ok a magas fényintenzitás érzékelése utáni jelátviteli utakban is szerepet játszhatnak. Az egyes ROSok közvetlen génregulációs szerepéről keveset tudunk, de a ROS-indukálható gének között találhatjuk a védekezésben szerepet játszó peroxidázokat, mint pl. az APX enzimeket is (Li és mtsai. 2009). Mivel a magas fényintenzitásra és az abiotikus stresszorok hatására 
indukálódó jelátviteli utak nagyban átfednek és sok keresztkapcsolatot tartalmaznak, elkülönítésük nehéz. Az antioxidáns enzimek transzkripciójának serkentése és az antioxidáns hatású vegyületek felhalmozódása általános oxidatív stresszválasznak tekinthető (Mittler 2002; Gill és Tuteja 2010). Összességében elmondható, hogy a változó fényhez való akklimáció egy homeosztatikus mechanizmus, melynek során a növény igyekszik fenntartani a hatékony fotoszintézisét a változó környezeti viszonyok között (Walters 2005).

\subsubsection{Az UV-sugárzás hatásai a növényekre}

Az ultraibolya (UV) a láthatónál rövidebb hullámhosszú és nagyobb energiájú sugárzást jelent, ami a Napból érkező elektromágneses sugárzás 100 és 400 nm közötti hullámhossztartományába esik. Ebböl az UV-C (100-280 nm) részt csaknem teljesen elnyeli az ózonréteg, azonban az UV-B (280-315 nm) sugárzás nagy része és az UV-A (315-400 nm) sugárzás eléri a földfelszínt, így ezek hatásával számolni kell. A növények

képesek érzékelni mind az UV-B mind az UV-A hullámhosszokat, előbbieket a nemrégiben felfedezett UV fotoreceptor (Fehér és mtsai. 2011; Heijde és Ulm 2012), utóbbiakat a fototropinok és kriptokrómok segítségével (Franklin és mtsai. 2005). Az UVsugárzás káros hatásait a növényekre már évtizedek óta ismerik és tanulmányozzák a kutatók, főképpen amióta az ózonréteg vékonyodását megfigyelték (pl. Caldwell és mtsai. 1989). A magasabb energiájú UV-B képes közvetlenül károsítani a DNS molekulát, a fehérjéket és a membránokat (Jansen és mtsai. 1998), azonban újabb kutatások szerint fontos szabályozó szerepe van a növekedésben és fejlődésben (Jansen és mtsai. 1998). Izolált, PS II tartalmú membránrészek UV-B besugárzása alapján kimutatható volt az elektrontranszport gátlása, amit elsősorban a vízbontó-komplexet ért közvetlen UVkárosításnak tulajdonítottak (Vass és mtsai. 1996). UV-B kezelt spenótlevelekből izolált tilakoidmembránan többféle gyökös termék kimutatható (hidroxilgyök, peroxilgyök, egyéb szénközpontú gyökök), ami többszintủ oxidatív stresszhatást jelez. Természetes rendszerekben az UV fotoszintézist károsító, illetve növekedésgátló hatását főképp a ROSközvetített oxidatív stressznek tulajdonítják (Agrawal és mtsai. 2009).

A kutatási eredmények igen sokféle, néha egymásnak ellentmondó hatásról is beszámoltak, aminek oka (a különböző fajú és korú növények használata mellett) az lehetett, hogy az üvegházi és szabadföldi, mesterséges UV-fényt használó módszerek mind más-más dózissal, illetve UV-B/PAR aránnyal történtek. A természetes napfényben 
megtalálhatóhoz közelibb UV dózisokkal és UV/PAR arányokkal végzett kísérletek megmutatták, hogy az UV csak részben károsító, és elsősorban inkább szabályozó hatással rendelkezik, ami a génexpresszióban és metabolizmusban okozhat jelentős változásokat (Middleton és Teramura 1993; Jansen 2002; Brosché és Strid 2003; Brown és mtsai. 2005; Frohnmeyer és Staiger 2003; Jenkins 2009). Sőt, az alacsony dózisú UV-B sugárzás szabályozó hatásának jelátviteli útját és magát a fotoreceptort (UVR8) is azonosították (Brown és mtsai. 2005; Heijde és Ulm 2012; Wu és mtsai. 2012). Valójában természetes vagy ahhoz közeli UV-szinteken ritka a növekedést vagy fejlödést ért károsító hatás (Ziska és mtsai. 1993; Hectors és mtsai. 2007; Ballaré és mtsai. 2011), ami arra utal, hogy ilyen körülmények között nem beszélhetünk oxidatív stresszröl. Ez azonban nem jelenti azt, hogy a ROS-oknak ne lenne szerepe a környezeti UV hatásában (Hideg és mtsai. 2013). Míg a magas UV-B dózisok közvetlenül mérhető ROS keletkezéséhez és oxidatív stresszhez vezetnek, addig az alacsonyabb dózisú, krónikus UV-szintek feltehetően alacsony koncentrációjú ROS közvetítette jelátviteli utakon keresztül részt vehetnek az akklimációs válaszok indukciójában (Brosché és Strid 2003). Ehhez a szabályozó hatáshoz tartozik a fenil-propanoid útvonal génjeinek aktiválása, a flavonoidok és antocianinok akkumulációja, az aszkorbát- és glutationszint növekedése, illetve egyes antioxidáns enzimek aktivációja (Jansen 1998). A fenolos vegyületek felhalmozódását UV-sugárzás hatására sokáig elsősorban fényszürő, UV-abszorbeáló funkciójuknak tulajdonították (Caldwell és mtsai. 1983; Kolb és mtsai. 2001), azonban a flavonoidok antioxidánsként is szerepet játszhatnak az UV elleni védelemben (Agati és Tattini 2010).

\subsection{Stressztolerancia és a redox homeosztázis}

Mivel az antioxidáns rendszer a számos környezeti faktor által előidézett ROSokozta károsodás elleni fő védelmet jelenti, a növények stressztoleranciájának növelésében gyakran alkalmazott stratégia a rendszer egyes komponenseinek megerősítése. Ennek módja föként antioxidáns enzimek túltermeltetése transzgénikus növényekben. A SOD, APX, CAT, GR vagy GST enzimeket fokozottan expresszáló növényekkel valóban sikerült egyes esetekben megnövekedett toleranciát elérni (l. például Allen 1995, Kuźniak 2002 vagy Gill és Tuteja 2010 összefoglalóját). Más esetekben a túltermelt célfehérje a kelációs fémek semlegesítésében (pl. ferritin, Zok és mtsai. 2010), vagy a már kialakult reaktív aldehidformák elleni védelemben (pl. aldehid-dehidrogenáz, Sunkar és mtsai. 2003) játszott szerepet. GSH- vagy AsA-túltermelő növényeknél is ki lehetett mutatni ilyen 
hatásokat, bár az eredmények igen ellentmondásosak voltak (1. Kuźniak 2002 összefoglalóját). Mindez nem meglepő, tekintettel arra, hogy a ROS molekuláknak fontos jelátviteli szerepük van, így képzésük teljes blokkolása akadályozhatja további stresszválasz útvonalak indukcióját. Ugyan bizonyos (általában mesterséges, laboratóriumi) körülmények között ezek a transzgénikus növények valóban mutattak egyfajta ellenállóságot oxidatív stressz okozta fotoszintézis- és növekedésgátlással szemben, azonban mind nyilvánvalóbb, hogy a stressztolerancia nem egyféle (vagy akár egyszerre több) enzim vagy antioxidáns megnövekedett koncentrációján múlik, hanem az egész antioxidáns hálózat és a sejt redox homeosztázisának komplex szabályozásán.

A stresszválaszokat alapvetően a potenciálisan oxidatívan károsító vegyületek (az összefoglaló néven prooxidánsoknak nevezett, reaktív oxigén- és nitrogénszármazékokat is magában foglaló csoport) és az antioxidánsok viszonya, egyensúlya határozza meg (Dat és mtsai. 2000; Foyer és Noctor 2009; Suzuki és mtsai. 2012). Normál fiziológiás viszonyok között (stresszmentes állapotban) a pro- és antioxidáns rendszer egyfajta egyensúlyi állapotban van, amelyet a sejt redox homeosztázisának nevezhetünk (Dietz 2003; Foyer és Noctor 2005). A 2. ábrán a magas fényintenzitás, illetve egyéb abiotikus környezeti stresszorok hatását láthatjuk vázlatosan a celluláris redox homeosztázis alakulásának függvényében. Magas fényintenzitás esetén az abszorbeált fény mennyisége meghaladja a fotoszintézis feldolgozóképességét, ami fokozott ROS-keletkezéssel jár és oxidatív stresszt indukál, illetve fotoinhibíciós hatást vált ki. A redox egyensúly a prooxidánsok felé tolódik el, ugyanakkor az oxidatív stressz vagy a ROS-ok közvetlenül olyan jelátviteli utakat indítanak be, amik védekezési mechanizmusok aktiválásához vezetnek (ezekben a jelátviteli utakban a hormonok jelentős szerepet játszanak). A környezeti faktorok optimálistól eltérő jelenléte közvetlenül (pl. toxikus elemek, herbicidek, nehézfémek), de legtöbbször inkább közvetve (vízhiány, sóstressz, árasztás, magas- vagy alacsony hőmérséklet) okozza a prooxidánsok fokozott termelődését a sejtekben. Ahol a hatás nem közvetlen, ott leginkább a sejtek ionhomeosztázisa felborulásának, illetve hiperozmotikus viszonyainak eredménye és a hormonok hatása (föképp etilén, abszcizinsav) a ROS-ok fokozott keletkezése. A magas fényintenzitás és a szuboptimális környezeti tényezők egymás hatását felerősítve fokozzák az oxidatív stresszt. Az abiotikus stresszhatások eredményeképpen képződött ROS-ok egyrészt a fotoszintetikus rendszer elemeinek további degradációjához vezetnek, másrészt az erőforrásokat a $\mathrm{CO}_{2}$-megkötésért felelős Calvin-ciklus enzimeitől elvonják, ezzel fényre „érzékenyítik” a növényt, azaz már kisebb fényintenzitásnál is telítődik a fotoszintetikus kapacitás, így jelentkezik a fotoinhibíció 
(Foyer és Shigeoka 2011). A kialakuló oxidatív károsodások közvetlenül, vagy közvetett módon (hormonok) sejthalálhoz vezethetnek. Másrészt a ROS-ok, vagy az oxidatív károsodás termékei jelként szolgálhatnak a védekező mechanizmusok beindításához (Van Breusegem et al. 2001; Apel és Hirt 2004; Foyer és Noctor 2005; Suzuki és mtsai. 2012). Ezek lehetnek az adott abiotikus stresszre specifikus, vagy olyan általános reakciók is, mint az antioxidáns enzimek vagy vegyületek produkciójának serkentése, illetve akár további ROS-képzés indukálása. Mivel a különböző ROS-ok a védekezésben is szerepet játszanak amit főképpen a patogének elleni védelmi utaknál tanulmányoztak (Wojtaszek 1997) -, a sejtek rendelkeznek saját, endogén ROS-előállító vagy -felszaporító mechanizmusokkal is (pl. NADPH oxidáz enzimek, 1. Sagi és Fluhr 2006). A homeosztatikus egyensúly helyreállása akklimációhoz vezet, amennyiben viszont ez nem történik meg, a sejt(ek), illetve a szervezet pusztulása következhet be.

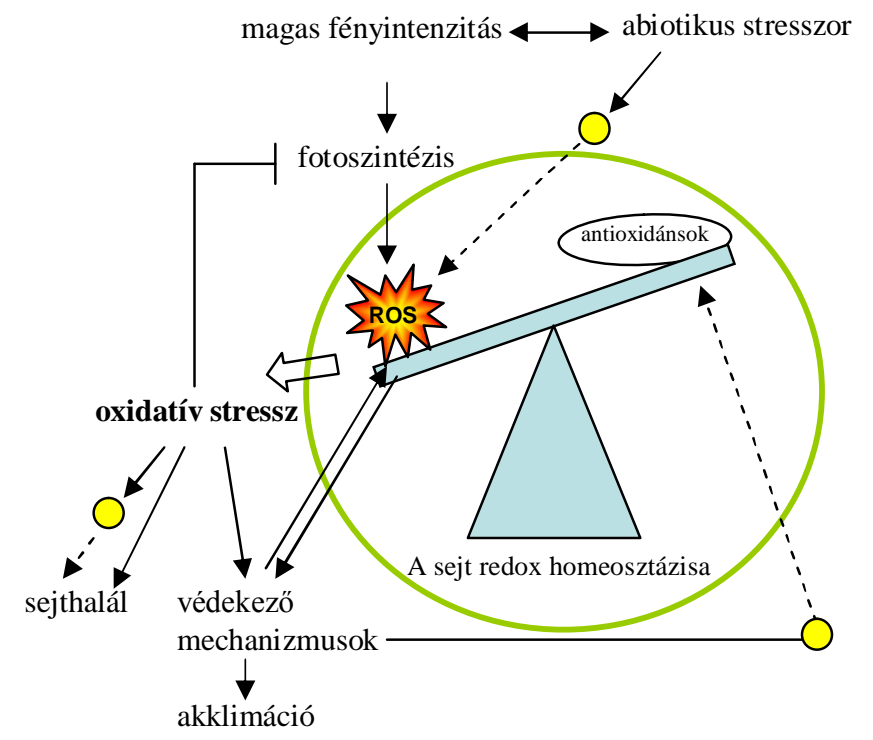

2. ábra: A fotoszintézis összefüggései a sejt redox homeosztázisával stresszhelyzetben, vázlatosan. A redox egyensúly felborulásával kialakuló oxidatív stressz sejthalálhoz, vagy a védekező mechanizmusok indukciójához vezethet. A sárga körök a nem közvetlen útvonalakat jelölik, egyéb jelátviteli anyagok, legjellemzőbben hormonok közremüködését jelzik. Az ábra Foyer és Shigeoka (2011) ábrájának módosított változata.

A sejtek redox homeosztázisa, amely a redukáló és oxidáló ágensek dinamikus egyensúlyi arányát jelenti a sejtben, valójában nem csak a stresszválaszok fő szabályozási pontja, hanem egy sokkal általánosabb és átfogóbb szabályozó szerepet tölt be a növények életében, mint a növényi metabolizmus és a környezeti ingerek közötti „kapcsolópont” 
(Foyer és Noctor 2009). Maga a szeneszcencia, a levelek szabályozott, természetes öregedési folyamata is egy ROS-közvetített jelenség, ami a pro-/antioxidáns egyensúly eltolódásának eredménye (Zentgraf és Hemleben 2008).

Érdemes megemlíteni azt is, hogy a prooxidáns-antioxidáns elkülönítés nem is mindig annyira egyértelmü, mivel például az aszkorbát vagy a tokoferol prooxidáns hatású is lehet, amennyiben vasredukáló képességük elősegíti a Fenton reakciót (Halliwell és Gutteridge 1999). Ezen kívül a fenolok is viselkedhetnek prooxidánsként, fenoxilgyökök kialakulásával (Sakihama és mtsai. 2002). A ROS-képződés és egymásba való átalakulás finom- és többszintü szabályozása, a keresztkapcsolatokon át történő kommunikáció (cross-talk), és a célzott, regulált megsemmisítésük teszi a proxidáns-antioxidáns hálózatot egy olyan komplex rendszerré, amelyben a ROS vegyületek alacsony szintje fontos jelátviteli szerepeket tölthet be.

\subsection{Mérések a növényi prooxidáns/antioxidáns rendszer állapotának meghatározására}

Amikor a növények súlyos stresszhatás alatt állnak, a pro- és antioxidáns viszonyaik egyértelmüen felborulnak, oxidatív stressz, membránkárosodás, lipidperoxidáció és további szabad gyökök toxikus felhalmozódása indul meg (Mittler 2002). Ez a folyamat jól követhető az oxidált molekulák detektálására alkalmas módszerekkel, például a malondialdehid, a membránon keresztül történő ion-kiáramlás, illetve a lipidperoxidáció termékeinek követésével (Shulaev és Oliver 2006; Jambunathan 2010). Maguk az elsődlegesen kialakuló ROS molekulák is detektálhatóak közvetlenül kolorimetrikus, elektron paramagnetikus rezonanciás méréssel, vagy fluoreszcens riporter molekulák segítségével (pl. szuperoxid: Barta és mtsai. 2004; hidrogén-peroxid: Šnyrychovà és Hideg 2007). Azonban ezek a módszerek csak akkor alkalmasak ROSdetektálásra, ha nagy mennyiségü, károsító hatású ROS van jelen (Hideg és mtsai. 2013). Amennyiben csak akklimációs folyamatról van szó, vagyis amikor az antioxidánsok mennyiségi vagy aktivitásbeli növekedése lépést tart a ROS-produkcióval (1. 2. ábrát), maguknak az antioxidánsoknak a vizsgálata adhat tájékoztatást a rendszer állapotáról.

$\mathrm{Az}$ antioxidáns enzimek expressziós szintjének változása viszonylag könnyen követhető, így ez egy gyakran alkalmazott módszer stresszhatások vizsgálatára (1. Gill és Tuteja 2010, illetve Karuppanapandian és mtsai. 2011 összefoglalóit és a bennük szereplő hivatkozásokat). Ilyenkor általában enzimaktivitás-növekedést lehet megfigyelni, mind az 
elsődleges védelmi vonal enzimeinél (pl. SOD, peroxidázok), mind az oxidált nemenzimatikus antioxidánsok regenerációjában szerepet játszó enzimek esetében. A génexpressziós válaszok, illetve az enzimproteinek mennyiségének mérése mellett az enzimaktivitásbeli változások is követhetőek jól ismert biokémiai módszerekkel, például színreakciókon alapuló fotometriás méréssel vagy natív gélelektroforézis segítségével. Akklimációs válaszok esetében azonban sokszor nem egyértelmüek a változások, egyes antioxidáns enzimek expressziója csökkenhet, míg másoké növekedhet (1. pl. Sharma és mtsai. 2012 összefoglalóját a témában), így az enzimatikus védelmi rendszer vizsgálatából nem mindig következtethetünk a ROS-viszonyokra.

\subsubsection{Teljes antioxidáns kapacitás (TAC) paraméterek}

A ROS-specifikus enzimek mellett nagy számú, nem specializált funkciójú antioxidáns is jelen van, így a kutatások az enzimatikus antioxidánsok egyedi azonosítása helyett sokszor egy másik megközelítést, az antioxidáns kapacitások vizsgálatát használják. Ez igen széleskörüen alkalmazott módszer, mind növényi eredetű élelmiszerek élelmezésügyi szempontból hasznosnak tartott antioxidáns-tartalmának vizsgálatára (Sun és Tanumihardjo 2007; Wu és mtsai. 2004), mind füszerek és gyógynövény-kivonatok hasonló célú elemzésére (Hossain és mtsai. 2008; Cai és mtsai. 2003; Katalinic és mtsai. 2006). A növénykivonatok teljes antioxidáns kapacitását (total antioxidant capacity, TAC) mérő módszerek használata olyan orvosi biokémiai vizsgálatokból ered, amelyek a vérplazma, illetve testfolyadékok antioxidáns jellemzőit voltak hivatottak elemezni (Young 2001). A céljukban azonos, de módszereikben különböző TAC próbáknak mára széles választéka, és egy-egy módszernek is különböző, továbbfejlesztett változatai állnak a kutatók rendelkezésére. Közös ezekben, hogy egyszerü eszközökkel (fluoriméter, fotométer) és viszonylag olcsón és gyorsan, nagy mintán is hatékonyan elvégezhetőek, így sorra születnek nagyléptékü analíziseket felvonultató tanulmányok, miközben sok kutató kritikai hangvételü írásai rávilágítanak a módszerek különbözőségéből eredő, vagy az adatok interpretációjában gyakran jelentkező hibákra (Arnao 2000; Frankel és Meyer 2000; Young 2001).

A TAC egy olyan integrált paraméter, ami egy többféle különböző antioxidáns vegyület komplex összességét tartalmazó mintát jellemez (Ghiselli és mtsai. 2000). Az alapul szolgáló kémiai reakciók szerint a TAC próbákat két csoportra szokás osztani: a hidrogénatom-transzfer (HAT) reakciókon alapuló és az elektrontranszfer (ET) reakciókon 
alapuló módszerekre (Huang és mtsai. 2005; Apak és mtsai. 2007). A két módszerben közös, hogy általában egy ismert antioxidáns vegyületre mint tiszta hatóanyagra (pl. AsA, Trolox, galluszsav) történik a kalibráció, és ehhez viszonyítva számszerüsíthető a minta antioxidáns kapacitása. A HAT-alapú megközelítések közös jellemzője, hogy a mintát (vizes vagy szerves oldószeres kivonatban) mesterségesen keltett szabadgyökkel reagáltatják, és annak antioxidáns-tartalmát a detektálható szabadgyök mennyiség csökkenésével jellemzik. Az általában peroxil- vagy alkoxil-szerkezetü gyökök kioltását az antioxidáns vegyület és a fluoreszcens próba kompetitív módon végzi, és a minta antioxidáns kapacitására a fluoreszcencia csökkenéséből lehet következtetni. Ebbe a csoportba taroznak a széles körben alkalmazott ORAC (oxygen radical absorbance capacity) és TRAP (total radical trapping antioxidant parameter), illetve a kevésbé ismert CBA (crocin bleaching assay) technikák.

Az ET-alapú technikák esetében az oxidáló potenciál megszüntetésének képességét, vagyis redukálóképességet mérünk, ami a próba színének (abszorpciójának) vagy fluoreszcenciájának változásával követhető nyomon. A redukálóképesség irányulhat prooxidánsként hatékony fémionokra, illetve mesterséges gyökvegyületek redukció útján történő semlegesítésére. Ebbe a csoportba tartozik a TEAC (Trolox equivalent antioxidant capacity), a teljes fenolosvegyület-tartalom meghatározása Folin-Ciocalteu reagens segítségével (TFT), a vasion-redukálóképesség (ferric ion reducing antioxidant power, FRAP), a rézion-redukálóképesség (cupric reducing antioxidant capacity, CUPRAC), és a DPPH (2,2-difenil-1-pikrilhidrazil) módszer. A reakciók kémiáján alapuló különbségek nyilvánvalóvá válnak, ha áttekintjük a szakirodalmat az azonos mintán mért TAC paraméterek közötti korrelációkat keresve. A redukálóképességet mérö ET-alapú tesztek gyakran mutatnak korrelációt, pl. a TEAC és FCR (Kirca és Arslan 2008) vagy a FCR és FRAP (Katalinic és mtsai. 2006) esetében, de a két különböző módszercsoporttal mért eredmények közötti korreláció ritka és nincs is elméleti megalapozottsága (l. Apak és mtsai. 2007). A fenti HAT és ET módszerek részletes leírását Ghiselli és mtsai. (2000) és Huang és mtsai. (2005) összefoglaló munkái tartalmazzák.

Könnyü kivitelezhetőségük és automatizálhatóságuk (pl. plate-reader segítségével) mellett a TAC paraméterek használatának hátránya, hogy csak az alacsony molekulasúlyú, oxidatív láncreakciót megtörő hatású antioxidánsokat kvantifikálják, és nem mérik a fémkötő fehérjék és enzimek hatását. Ezen kívül egyes módszerek csak a vízoldékony (pl. TFT), míg mások csak a lipidoldékony antioxidánsok (pl. DPPH) mérésére alkalmasak, a módszerekben alkalmazott oldószerektől függően (Pérez-Jiménez és Saura-Calixto 2006). 
Emellett egy komplex biológiai mintában előfordulhatnak interferencia-hatások is, amik miatt a kapott antioxidáns aktivitások nem eredeztethetőek közvetlenül a mintát alkotó egyes antioxidánsok hatásából (Pérez-Jiménez and Saura-Calixto 2006; Apak és mtsai. 2007).

\subsubsection{Specifikus antioxidáns kapacitás (SAC) mérések}

A fentiekben bemutatott TAC próbák mellett ismertek olyan eljárások is, melyek a szintetikus szabad gyökök helyett a minta specifikus, egyetlen ROS-ra szelektív kioltókapacitását mérik. A ROS-ok között csak két olyan van, amit specifikus enzimek semlegesítenek: a SOD a $\mathrm{O}_{2}{ }^{\circ-}$, illetve a peroxidázok a $\mathrm{H}_{2} \mathrm{O}_{2}$ esetében. Fontos megjegyezni, hogy specifikus gátlószerekkel végzett kiegészítő mérések hiányában még a „klasszikus” enzimaktivitás-mérő eljárások eredményei is magukban foglalják a mintákban jelen levő nemenzimatikus utak okozta kioltásokat, bár ezek mértéke általában sokkal kisebb mint az enzimatikus utaké. A $\mathrm{O}_{2}{ }^{\circ}$ és $\mathrm{H}_{2} \mathrm{O}_{2}$ azonban kivételesek, mert ezeken kívül más ROS-ok semlegesítését nem célozzák specifikus enzimek. A ${ }^{\circ} \mathrm{OH},{ }^{1} \mathrm{O}_{2}, \mathrm{RO}_{2}{ }^{\bullet}$ vagy a $\mathrm{OONO}^{-}$ semlegesítése általában több vegyület együttes hatása. Az antioxidáns-kapacitás mérések specifitása azon múlik, hogy találjunk egy megfelelö ROS-képzö rendszert, illetve egy olyan próbát, ami az adott ROS-sal szelektíven és a minta antioxidánsaival kompetitív módon reagál (közvetlenül, vagy reakció intremediereken keresztül), és a reakció bekövetkezését fluoreszcencia- vagy színváltozással jelzi. A reakciót az antioxidánstartalmú növényi kivonatok hiányában, illetve jelenlétében méréssel követve meghatározható az a kivonat-koncentráció, ami a reakciót 50\%-ban gátolja (half inhibition concentration, $\left.\mathrm{IC}_{50}\right)$.

A legismertebb és legtöbbet alkalmazott ilyen módszer a SOD-aktivitás mérés, ami egy kompetitív kinetika alapú technika, ahol a próba színének vagy fluoreszcenciájának változása nyomán következtethetünk a hozzáadott kivonat antioxidáns kapacitására. $\mathrm{A} \mathrm{O}_{2}{ }^{*-}$ képzésére leggyakrabban a xantin/xantin-oxidáz rendszert használják (McCord és Fridovich 1969), de nemenzimatikus források is ismertek (Ewing és Janero 1995). Ez a mérés a fent leírtak alapján alkalmas az enzimatikus és a nemenzimatikus $\mathrm{O}_{2}{ }^{\circ}$-kioltó képesség meghatározására is. A hidroxilgyök-kioltó képesség mérésekor a gyököt általában a Fenton-reakció segítségével képzik (1. a 2.2. fejezetet). A •OH-reaktív antioxidánsok mérésére az egyik legkorábban alkalmazott technika a dezoxiribóz tesztmódszer volt (Gutteridge and Halliwell 1988), de mi a laborunkban kifejlesztett 
pontosabb és növényi rendszerekben jobban alkalmazható módszert alkalmaztunk (Šnyrochova és Hideg 2007). A ${ }^{1} \mathrm{O}_{2}$-t általában fényérzékenyített reakcióban képzik, egy festék megvilágításával, ami többletenergiáját a molekuláris oxigénnek továbbítja. $\mathrm{A}^{1} \mathrm{O}_{2}$ képződése és kioltása a molekulára jellemző 1270 nm-es foszforeszcencia detektálásával közvetlenül is mérhető (Macpherson és mtsai. 1993), vagy közvetett módon ${ }^{1} \mathrm{O}_{2}{ }^{-}$ szenzitizált próba alkalmazásával (Kraljic and El Moshni 1978; Fu és mtsai. 1993). A jelen munkában alkalmazott módszerek részletes leírását az Anyag és módszer fejezet tartalmazza. 


\section{CÉLKITÜZÉSEK}

Vizsgálataink során különböző, üvegházban mesterségesen megválasztott, vagy szabadföldi fényviszonyok közt nevelkedett növények antioxidánsait térképeztük fel, hogy megvizsgáljuk ezek szerepét a változó fényviszonyokhoz történő akklimációban. Elsősorban az alacsony, természeteshez közeli dózisú UV-sugárzáshoz történő alkalmazkodási folyamatokat vizsgáltuk, a természetben mindig jelen levő fotoszintetikusan aktív fény (PAR) háttérrel. Mivel az UV alkalmazkodási folyamatokban nem jellemző nagy mennyiségü ROS jelenléte a levelekben, legalábbis ezek közvetlen kísérleti kimutatása a rendelkezésre álló kísérleti módszerek érzékenységi küszöbe alá esik (Hideg és mtsai. 2013), az akklimációt a levelek antioxidáns viszonyainak tükrében vizsgáltuk. Ehhez a kivonatok teljes és ROS-specifikus antioxidáns kapacitásait (TAC és SAC) mérő módszereket használtunk fel. A széles körben használt általános, kivonatok teljes antioxidáns kapacitását leíró paraméterek (TEAC, FRAP, TFT) mellett a szuperoxidgyök kioltását, illetve a hidroxilgyök és szinglett oxigén elleni szelektív antioxidáns kapacitás-mérő próbák laborunkban továbbfejlesztett változatait alkalmaztuk. Elemeztük továbbá az UV-B abszorbeáló pigmentek és karotenoidok szerepét is. A vizsgálatokat különböző növényeken (szőlö, dohány, hárs) és meglehetősen eltérő kísérleti beállításokon (üvegházi, szabadföldi) keresztül végeztük, hogy átfogóbb képet nyerhessünk az antioxidáns változások és a környezeti alkalmazkodás összetett viszonyáról. Kutatásaink fó célja annak elemzése volt, mennyire jellemzi az ezekkel a paraméterekkel mérhető antioxidáns-tartalom a növények fényakklimációját. Ennek során a következő kérdésekre kerestük a válaszokat:

1. Mennyire reagálnak érzékenyen a különböző TAC és SAC próbák a levelek eltérő fiziológiai állapotát kísérő antioxidáns változásokra?

2. Milyen összefüggések vannak a levelek TAC és SAC értékei és természetes (szeneszcencia, kor) illetve mesterséges (a nevelési fényhez képest magasabb fényintenzitás, UV-sugárzás) hatásokra megváltozó fiziológiai állapota között?

Ezt a kérdést két megközelítésben vizsgáltuk, egyrészt hogy

a) eltérnek-e a levelek válaszai az üvegházi körülmények között alkalmazott kiegészítő UV sugárzásra korukból eredő antioxidáns-tartalombeli különbségeinek függvényében, 
b) másrészt hogy javítható-e a növények UV akklimációs válasza az antioxidánstartalom előzetes megváltoztatásával?

3. A természetes napfényhez való alkalmazkodásban milyen szerepe van a ROSkioltásnak illetve a flavonoidoknak? 


\section{ANYAGOK ÉS MÓDSZEREK}

\subsection{Növénynevelés és kezelések}

4.1.1. A levelek antioxidáns-tartalma és fiziológiai állapota közti összefüggések vizsgálatára használt dohányok nevelési körülményei

A levelek korának antioxidáns-tartalom méréséhez használt dohány (Nicotiana tabacum L. cv. Petite Havana) növényeket általános virágföldbe (Florimo, Matécsa Kertészeti Kft. Magyarország) vetettük és (16 cm átmérőjü cserépbe való) átültetést követően üvegházban neveltük napi 16 órás megvilágítással $200 \mu \mathrm{mol}$ foton $\mathrm{m}^{-2} \mathrm{~s}^{-1}$ PAR fényen (LI-250 radiométer, LI-COR Environmental, Lincoln, NE, USA) és 25/20 ${ }^{\circ} \mathrm{C}$ (nappali/éjszakai) hőmérsékleten. A vizsgálatokhoz a 4-12 hetes növények különböző korú leveleit használtuk (a levelek azonosítói: L1-L7, kor szerint növekvő sorrendben). A klorofill fluoreszcencia változáson alapú fotokémiai jellemzők mérését (4.3. fejezet) követően a levelekből 10 mm átmérőjü korongokat vágtunk ki és használtunk fel a további mérésekhez.

\subsubsection{Szölö üvegházi nevelési körülményei és az UV-kezelés}

A szőlöt (Vitis vinifera L. cv. Chardonnay) $20 \mathrm{~cm}$ átmérőjü müanyag zsákokban, virágföld és vermikulit keverékéből álló talajban kaptuk Dr. Váradi Gyulától (Budapesti Corvinus Egyetem, Kecskeméti Kutató Állomás), majd üvegházi körülmények között, természetes fényviszonyok mellett (max. $200 \mu$ mol foton $\mathrm{m}^{-2} \mathrm{~s}^{-1}$ PAR, UV-mentes) neveltük. A növekedés során a hajtásokat vízszintes karókra futtattuk fel, úgy, hogy a levelek többsége ugyanazon a szinten és színével felszínével felfelé helyezkedjen el. A kezelésekhez a növényeket két csoportra osztottuk. Az egyik csoport további 4 napon át napi 12 órás, $50 \mu \mathrm{mol}$ foton $\mathrm{m}^{-2} \mathrm{~s}^{-1}$ PAR mellett nőtt, míg a másik ugyanekkora megvilágítás mellett napi 6 órán keresztül 0,84 $\mathrm{W} \mathrm{m}^{-2}$ UV-B dózissal (97503-00 ColePalmer radiométer, Cole-Parmer Instrument Co. Ltd., London, UK) volt besugározva. A megvilágításhoz Q-Panel UVB-313EL (Koninklijke Philips Electronics N.V.) fénycsöveket használtunk, amit cellulóz-acetát filterrel (Courtaulds Chemicals, Derby, UK) takartunk a $290 \mathrm{~nm}$ alatti hullámhosszok kiszüréséhez. Az alkalmazott UV-sugárzás spektrális eloszlását Newport OSM-400UV/VIS spektrométerrel Dr. Andreas Albert 
mérései alapján (Helmholtz Zentrum, München, No.) a 3. ábra mutatja. A 4 napos kezelés során alkalmazott biológiailag effektív UV-dózis (BED) napi 8,95 kJ m² (290-400 nm) volt (amelynek nagy része, $8,04 \mathrm{~kJ} \mathrm{~m}^{-2}$ az UV-B tartományba esett). A BED számítását a Flint és Caldwell (2003) által javasolt spektrum biológiai súlyozására szolgáló függvény (biological spectral weighting function, BSWF) felhasználásával végeztük.

A leveleket ezután két csoportra elkülönítve vizsgáltuk: fiatal levelek (FL), a csúcstól számított első 3 teljesen kifejlett, 1-3 hetes levél); idős levelek (IL), a csúcstól számított 4-9. kifejlett, de még a szeneszcencia jegyeit nem mutató 4-6 hetes levelek. A 4 kezelési csoportban (FL-PAR, FL-UV, IL-PAR, IL-UV) csoportonként 3-9 levelet vizsgáltunk. A gázcsere és klorofill fluoreszcencia mérések után a levelekből $10 \mathrm{~mm}$ átmérőjü korongokat vágtunk ki és használtunk fel a kivonatok elkészítéséhez.

3. ábra: A kiegészító UV-

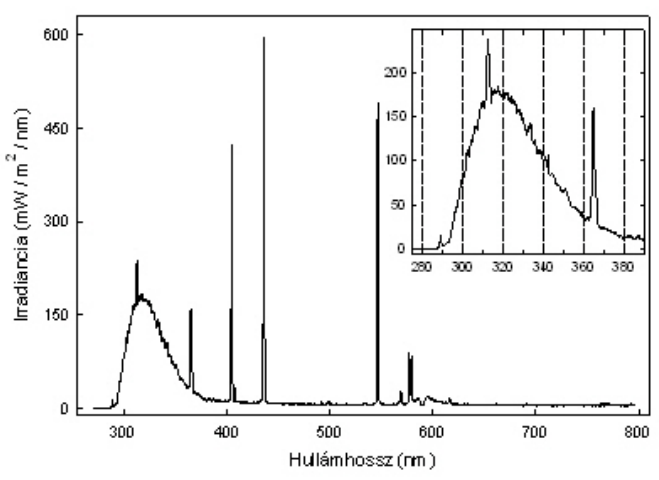

sugárzásos kísérletekben a megvilágítás spektrális eloszlása. Az UV-fényt a Q-Panel UVB-313EL (Koninklijke Philips Electronics N.V.) fénycsövek adták, a $290 \mathrm{~nm}$ alatti hullámhosszokat cellulóz-acetát filterrel (Courtaulds Chemicals, Derby, UK) szürtük ki. A mérést Newport OSM-400UV/VIS spektrométerrel Dr. Andreas Albert végezte.

\subsubsection{A magas fényintenzitású elökezelés UV-akklimációban játszott szerepének} vizsgálatára használt dohányok nevelése és a UV-kezelés körülményei

A dohány (Nicotiana tabacum L. cv. Petite Havana SR1) növényeket általános virágföldbe (Florimo, Matécsa Kertészeti Kft. Magyarország) vetettük és (16 cm átméröjü cserépbe való) átültetést követően üvegházban neveltük, napi 12 órás megvilágítással 200 $\mu \mathrm{mol}$ foton $\mathrm{m}^{-2} \mathrm{~s}^{-1}$ PAR fényen (LI-250 radiométer, LI-COR Environmental, Lincoln, NE, USA) és $25 / 20{ }^{\circ} \mathrm{C}$ hőmérsékleten. A 6 hetes növényeket két csoportra osztottuk az előkezelésekhez. Az egyik csoportot napi 12 órán át $200 \mu \mathrm{mol}$ foton $\mathrm{m}^{-2} \mathrm{~s}^{-1} \mathrm{PAR}$ fényen tartottuk továbbra is, míg a másikat $1000 \mu \mathrm{mol}$ foton $\mathrm{m}^{-2} \mathrm{~s}^{-1}$ PAR fényre helyeztük 5 napra, szintén napi 12 órás megvilágítással. Ezután további 2-2 csoportra osztva a növényeket, az 
egyik $200 \mu \mathrm{mol}$ foton $\mathrm{m}^{-2} \mathrm{~s}^{-1}$ PAR mellett 6 napon át, napi 8 órában kiegészítő UVsugárzást kapott, míg a másik nem. Az UV-megvilágítás körülményei a 4.1.2. pontban leírtakkal egyezőek voltak.

Mind a négy kezelési csoport 3 növényt tartalmazott, és minden növényröl egy, a többivel azonos magasságban lévő és korú levelet használtunk fel a mérésekhez. Gázcsereanalízis és klorofill fluoreszcencia mérést követően a levelekből $10 \mathrm{~mm}$ átmérőjü korongokat vágtunk ki és használtunk a továbbiakban.

\subsubsection{A szabadföldön nött hársfa növekedési körülményei és a levelek begyüjtése}

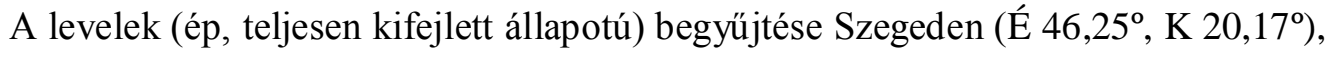
egy nagylevelü hársfa (Tilia platyphyllos Scop.) csaknem egész nap napfénynek kitett, illetve árnyékban lévő részeiről történt 2010 júliusában, reggeli időpontban, egy hosszabb száraz és napos időjárású periódus után. Felhőmentes napokon a maximális jellemző PAR értékek a fényleveleeknél (FL) 1700-1800 $\mu \mathrm{mol}$ foton $\mathrm{m}^{-2} \mathrm{~s}^{-1} \mathrm{PAR}$, míg az árnyéklvevelek (ÁL) esetében 80-100 $\mu$ mol foton $\mathrm{m}^{-2} \mathrm{~s}^{-1}$ PAR körül alakultak (97503-00 Cole-Palmer radiométer, Cole-Parmer Instrument Co. Ltd., London, UK). A jellemző biológiailag effektív UV-B dózis ezen a területen átlagosan napi $7.5 \mathrm{~kJ} \mathrm{~m}^{-2}$ (Bassman és mtsai. 2001).

Az 5 FL és 5 ÁL klorofill fluoreszcenciáját a begyüjtést követő 30 perces sötétadaptáció után mértük, majd a leveleket folyékony nitrogénben lefagyasztottuk és fagyasztva tároltuk. Felhasználás előtt a levélmintákatat $-85{ }^{\circ} \mathrm{C}$ hőmérsékleten és 0.060 mbar nyomás alatt liofilizáltuk (Christ Alpha 2-4 LD Freeze dryer, SciQuip Ltd, UK).

\subsection{Fotoszintézismérés gázcsere-analizátor segítségével}



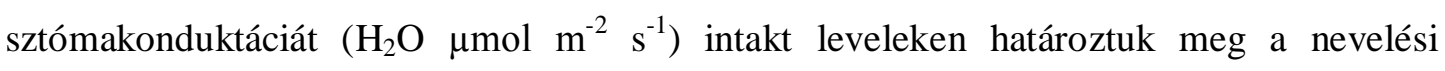
fényintenzitáson és hőmérsékleten, LI-6400 hordozható gázcsere-analizátor segítségével (LI-COR Environmental, Lincoln, Nebraska, USA).

\subsection{Fotokémiai jellemzők meghatározása klorofill fluoreszcencia méréssel}

A klorofill fluoreszcencia méréséhez a levágott (vízzel átitatott vattába csavart nyelü) leveleket először 30 percig sötétben tartottuk, majd az Imaging-PAM (Heinz Walz GmbH, 
Effeltrich, Németország) műszer MAXI-mérőfejének segítségével végeztük a mérést. A sötétadaptált leveleknek meghatároztuk a minimális fluoreszcencia $\left(\mathrm{F}_{0}\right)$, és egy telítő fényimpulzos segítségével a maximális fluoreszcencia $\left(\mathrm{F}_{\mathrm{m}}\right)$ paramétereit, majd az $\mathrm{F}$ és $\mathrm{F}_{\mathrm{m}}{ }^{\prime}$ paramétereket 5 percig tartó $55 \mu \mathrm{mol} \mathrm{m}^{-2} \mathrm{~s}^{-1}$ PAR megvilágítás után. A következő képletek alapján számoltunk (Genty és mtsai. 1989; Schreiber és mtsai. 1986):

- PS II maximális fotokémiai hatékonysága

$$
\mathrm{F}_{\mathrm{v}} / \mathrm{F}_{\mathrm{m}}=\left(\mathrm{F}_{\mathrm{m}}-\mathrm{F}_{0}\right) / \mathrm{F}_{\mathrm{m}}
$$

- „effektív” vagy fényadaptált fotokémiai hatékonyság

$$
\mathrm{Y}_{\mathrm{PSII}-55}=\left(\mathrm{F}_{\mathrm{m}}{ }^{\prime}-\mathrm{F}\right) / \mathrm{F}_{\mathrm{m}}{ }^{\prime} \text {. }
$$

A hársleveleken történő klorofill fluoreszcencia mérésnél az $\mathrm{F}$ és $\mathrm{F}_{\mathrm{m}}$ 'értékeket több,

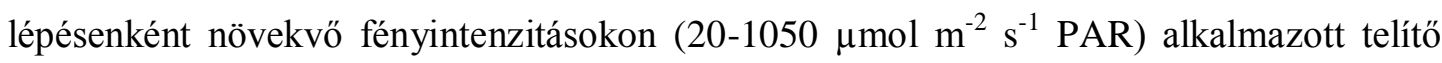
fényimpulzus elött $(F)$ illetve után $\left(F_{m}^{\prime}\right)$ is felvettük, és ezekből Klughammer és Schreiber (2008) leírása alapján alapján minden fényintenzitáson kiszámítottuk az abszorbeált fény fotokémiai hasznosítására jellemző három paramétert $\mathrm{Y}(\mathrm{II})+\mathrm{Y}(\mathrm{NO})+\mathrm{Y}(\mathrm{NPQ})=1$, ahol az összetevők a következőképp számolhatók:

- „effektív” vagy fényadaptált fotokémiai hatékonyság,

$$
\mathrm{Y}_{\mathrm{PSII}}=\left(\mathrm{F}_{\mathrm{m}}{ }^{\prime}-\mathrm{F}\right) / \mathrm{F}_{\mathrm{m}}{ }^{\prime}
$$

- szabályozatlan energia leadási frakció,

$$
\mathrm{Y}_{\mathrm{NO}}=\mathrm{F} / \mathrm{F}_{\mathrm{m}}
$$

- $\quad$ szabályozott energia leadási frakció

$$
\mathrm{Y}_{\mathrm{NPQ}}=\mathrm{F} / \mathrm{F}_{\mathrm{m}}{ }^{\prime}-\mathrm{Y}_{\mathrm{NO}}
$$

\subsection{Pigmenttartalom meghatározása}

\subsubsection{Karotenoidtartalom mérése}

A karotenoidtartalom meghatározásához a kivágott levélkorongok pigmentjeit a friss súly lemérése után 80\%-os acetonban vontuk ki $4{ }^{\circ} \mathrm{C}$-on sötétben 24 órán át, majd homogenizálást és centrifugálást $\left(3000 \times \mathrm{g}, 5\right.$ perc, $\left.4{ }^{\circ} \mathrm{C}\right)$ követően mértük a felülúszó abszorbanciáját spektrofotométer segítségével (Shimadzu UV-1601). Az OD értékeket a 735 nm-en mért értékkel korrigáltuk. A friss levélsúlyra meghatározott karotenoidtartalmat a következő képlet alapján számoltuk (Yang és mtsai. 1998):

- $\mathrm{Kar}=4,69 \cdot \mathrm{OD}_{440,5}-0,267 \cdot \mathrm{Kl}$, ahol a $\mathrm{Kl}$ a klofilltartalom,

- $\mathrm{Kl}=17,76 \cdot \mathrm{OD}_{646,6}+7,34 \cdot \mathrm{OD}_{663,6}$. 


\subsubsection{UV-B abszorbeáló pigmentek meghatározása}

Az UV-B abszorbeáló pigmentek méréséhez a kivágott levélkorongokat a friss súly meghatározása után savas metanolban (79 v/v\% metanol, 20 v/v\% $\quad \mathrm{H}_{2} \mathrm{O}, 1$ v/v\% $\left.\quad \mathrm{HCl}\right)$ inkubáltuk $4{ }^{\circ} \mathrm{C}$-on sötétben 24 órán át, majd homogenizálás és centrifugálás (3000 g, 5 perc, $4{ }^{\circ} \mathrm{C}$ ) után mértük a felülúszó abszorbanciáját spektrofotométer segítségével (Shimadzu UV-1601). Az UV-B abszorpciót a 280-315 nm hullámhosszon történő OD értékek integrálása adta, amit friss levélsúlyra meghatározva adtunk meg: $\Sigma \mathrm{OD}_{280-315} \mathrm{~g}^{-1}$ (Mirecki és Teramura 1984).

\subsection{Teljes antioxidáns kapacitás paraméterek meghatározása}

A teljes antioxidáns kapacitás próbákhoz a levélkorongok vizes kivonatait használtuk fel. Ehhez a levélkorongokat súlyuk meghatározása után folyékony nitrogénben fagyasztottuk, majd eldörzsöltük. A kivonatokat semleges (pH 7,0) 1 mM EDTA tartalmú 50 mM Na-foszfát hozzáadásával, majd a pufferben való homogenizálással készítettük. A sejttörmeléket először egy alacsony sebességü centrifugálással (3000 g, 5 perc, $\left.4{ }^{\circ} \mathrm{C}\right)$ eltávolítottuk, majd a felülúszókat újracentrifugáltuk (30.000 g, 25 perc, $\left.4{ }^{\circ} \mathrm{C}\right)$, hogy fotometriás mérésekhez alkalmas, tiszta kivonatokat kapjunk.

\subsubsection{Teljes fenolosvegyület-tartalom mérése}

A teljes fenolosvegyület-tartalom meghatározása a Folin-Ciocalteu (FC) reagenssel (Ferak Berlin) történt Veliglu és mtsai. (1998) leírása szerint. A levélkivonatokat (40-100 $\mu \mathrm{l})$ az előzőleg 10-szeresére higított $500 \mu$ l végtérfogatú FC reagenshez adtuk, majd 5 perc eltelte után további $500 \mu \mathrm{Na}_{2} \mathrm{CO}_{3}\left(60 \mathrm{~g} \mathrm{l}^{-1}\right.$ töménységü) oldatot adtunk a keverékhez. A 90 perces szobahőmérsekleten történő inkubáció után mértük az abszorbanciát $725 \mathrm{~nm}$ hullámhosszon (Shimadzu UV-1601). Ugyanilyen módon különböző töménységü galluszsav (gallic acid, GA) oldatok esetén is meghatároztuk az abszorbanciaértékeket, és a növényi kivonatok teljes fenolosvegyület-tartalmának értékét levél friss súlyra vonatkoztatott galluszsav ekvivalensekben fejeztük ki ( $\mu$ g GA ekv. $\left.\mathrm{g}^{-1}\right)$.

\subsubsection{Trolox ekvivalens antioxidáns kapacitás teszt}


A TEAC a kivonatok antioxidáns képességét méri egy mesterséges gyökkel (2,2azino-bisz-3-etilbenzotiazolin-6-szulfonsav, $\mathrm{ABTS}^{\bullet+}$ ) szemben. A módszert eredetileg Miller és mtsai. (1993) fejlesztették ki vérplazma vizsgálatára, de azóta számos továbbfejlesztett változata is ismert. A pontosabb, színtelenítésen alapuló technikák esetén először a színes (kék) gyökös anyag előállítása történik, majd a levélkivonat hozzáadása után 730 nm-en mért abszorpció csökkenése alapján határozható meg a minta antioxidáns kapacitása.

Az általunk alkalmazott teszben az ABTS-gyököt 0,1 mM ABTS (Sigma-Aldrich), 0,0125 $\mu \mathrm{M}$ peroxidáz (Sigma-Aldrich) és $1 \mathrm{mM} \mathrm{H}_{2} \mathrm{O}_{2}$ (Merck) tartalmú $50 \mathrm{mM}$-os savas (pH 6,0) Na-foszfát pufferben képeztük (Rice-Evans és Miller 1994). A késleltetésen alapuló eljárás során (Re és mtsai. 1999) a levélkivonatokat (40-100 $\mu 1$ ) a gyökképződés maximumának elérése (15 perc) után adtuk az oldathoz $(1 \mathrm{ml})$, majd további 2 perc után az abszorbanciát 730 nm-en mértük spektrofotométerrel (Shimadzu UV-1601). A kalibráció ugyanilyen módon történt, különböző töménységü Trolox, egy szintetikus vízoldékony Evitamin származék (6-hidroxi-2,5,7,8-tetrametilkromán-2-karboxilsav, Sigma-Aldrich) hozzáadásával, és ez alapján a növényi kivonatok TEAC értékét levél friss súlyra vonatkoztatott Trolox ekvivalensekben fejeztük ki ( $\mu$ g Trolox ekv. $\mathrm{g}^{-1}$ ).

\subsubsection{Vasion-redukálóképesség teszt}

A FRAP tesztet az eredeti biokémiai eljárás (Benzie és Strain 1996) Szőllősi és Szőllősi-Varga (2002) által továbbfejlesztett változata szerint végeztük. A próba a Fe(II)TPTZ (2,4,6-tripiridil-S-triazin) komplex alacsony pH-n történő redukciójának [Fe(III)TPTZ] és az ezzel járó színváltozásnak a spektrofotometriás követésén alapul. A FRAP reagens képzéséhez először $25 \mathrm{ml}$ savas acetát pufferhez $(300 \mathrm{mM}$, pH 3,6) adtunk 2,5 ml TPTZ oldatot (10 mM TPTZ $40 \mathrm{mM}$-os HCl-ben) és $2,5 \mathrm{ml} \mathrm{FeCl}{ }_{3}$ oldatot $(20 \mathrm{mM}$ desztillált vízben). Az oldat $1 \mathrm{ml}$-éhez változó mennyiségü (10-100 $\mu \mathrm{L}$ ) levélkivonatot adtunk, majd 30 perc szobahőmérsékleten történő inkubáció után mértük az abszorpció növekedését a kivonat hozzáadása nélküli oldathoz viszonyítva, 593 nm hullámhosszon (Shimadzu UV-1601). A kalibráció ugyanezen a módon történt, különbözö töménységü AsA (Reanal) oldatok hozzáadásával, és ez alapján a növényi kivonatok FRAP értékeit levél friss súlyra vonatkoztatott AsA ekvivalensekben fejeztük ki ( $\mu \mathrm{g}$ AsA ekv. $g^{-1}$ ).

\subsection{Specifikus antioxidáns kapacitás paraméterek meghatározása}


A specifikus antioxidáns kapacitás próbákhoz a levelek vizes (dohány, szőlő), illetve vizes-metanolos (hárs) kivonatait használtuk fel. A vizes kivonatok elkészítéséhez a levélkorongokat súlyuk meghatározása után folyékony nitrogénben fagyasztottuk, majd eldörzsöltük. A kivonatokat semleges (pH 7,0), 1 mM EDTA tartalmú 50 mM Na-foszfát hozzáadásával, majd a pufferben történő eldörzsöléssel készítettük. A sejttörmeléket egy alacsony erősségü centrifugálással $\left(3000 \mathrm{~g}, 5\right.$ perc, $\left.4{ }^{\circ} \mathrm{C}\right)$ eltávolítottuk, majd a felülúszókat újracentrifugáltuk (30000 g, 25 perc, $\left.4{ }^{\circ} \mathrm{C}\right)$, hogy fotometriás mérésekhez alkalmas, tiszta kivonatokat kapjunk. A fagyasztva szárított hárslevelekből a szinglett oxigén kioltásának méréshez 50\%-os metanolos oldatban kivonatot készítettuink dörzsöléssel, majd centrifugálással (30.000 g, 25 perc, $\left.4{ }^{\circ} \mathrm{C}\right)$.

\subsubsection{Szuperoxid-kioltó képesség mérése}

A SOD-aktivitás teszt néven ismert (az enzimatikus és a nemenzimatikus hozzájárulást is mérő) módszer a levélkivonatok antioxidánsainak azon képességét határozza meg, hogy megakadályozzák az NBT (nitro blue tetrazolium) $\mathrm{O}_{2}{ }^{--}$-indulálta formazánná való átalakulását (Beuchamp és Fridovich 1971; Giannopolitis 1977). Az eljárás során a $\mathrm{O}_{2}{ }^{-}$-képzés xantinból enzimes úton, xantin-oxidáz hatására történik. A reakcióelegy Na-foszfát pufferben $(50 \mathrm{mM}, \mathrm{pH} 7,2)$ a következőket tartalmazta: 0,015 U xantin oxidáz, 0,2 mM xantin, 0,3 mM EDTA és $1 \mathrm{mg} \mathrm{ml}^{-1} \mathrm{NBT}$ (Sigma-Aldrich). Az oldat 1 ml-éhez különböző mennyiségü (10-100 $\mu$ l) kivonatokat adva követtük a formazán kialakulásának gátlását az $540 \mathrm{~nm}$ hullámhosszon mért abszorbancia alapján (Shimadzu UV-1601). A görbe kezdeti (kivonat hozzáadása elötti) növekedése (slope 0, S0), illetve a kivonat hozzáadása utáni növekedési rátája (S) alapján számoltuk az 50\%-os inhibíciós koncentrációt (a hidroxilgyök-kioltó képesség mérésénél alábbiakban leírtak szerint). A mérést szuperoxid-dizmutáz enzim (Sigma-Aldrich) különböző koncentrációival hasonló módon elvégezve szintén meghatároztuk az 50\%-os inhibíciójához tartozó $\mathrm{IC}_{50}$ értéket, majd a levelek $\mathrm{O}_{2}{ }^{--}$antioxidáns kapacitását friss súlyra vonatkoztatva SOD ekvivalensekben fejeztük ki ( $\mathrm{IC}_{50} \mathrm{U}$ SOD ekv. $\left.\mathrm{g}^{-1}\right)$.

\subsubsection{Hidroxilgyök-kioltó képesség mérése}

A specifikus hidroxilgyök-kioltó képesség mérésének alapelve a levélkivonatok antioxidánsainak azon képessége, hogy megakadályozzák a tereftalátsav (TPA) és az ${ }^{\bullet} \mathrm{OH}$ reakciójából keletkező 2-hidroxitereftalátsav (HTPA) képződését (Šnyrychová és Hideg 
2007). A •OH képzése a Fenton reakció alapján történik (Halliwell és Gutteridge 1999). A 2,5 ml reakcióelegy a következő anyagokat tartalmazta Na-foszfátban (50 mM, pH 7,2) oldva: $500 \mu \mathrm{M}$ TPA, $10 \mu \mathrm{M}$ EDTA, $10 \mu \mathrm{M} \mathrm{FeSO}_{4}, 100 \mu \mathrm{M}$ AsA és $100 \mu \mathrm{M} \mathrm{H}_{2} \mathrm{O}_{2}$ (SigmaAldrich illetve Reanal). A HTPA képződése a fluoreszcencia intenzitás növekedés alapján követhető, 315 nm-en történő gerjesztés mellett $420 \mathrm{~nm}$ hullámhosszú emisszió alapján (Quanta Master QM-1 spektrofluoriméter, Photon Technology Inc., Birmingham, NJ, USA). A mérés során először egy kezdeti HTPA fluoreszcencia növekedési görbét vettünk fel (slope 0, S0), majd a növényi kivonatok hozzáadásával mértük a görbe alakulását (S). A szoftveres kiértékelés során lineáris egyenest illesztettünk a $\log [$ koncentráció] - $\log [\mathrm{S} 0 / \mathrm{S}$ 1] adatpárokra és kiszámítottuk a fluoreszcencianövekedés 50\%-os inhibíciójához tartozó koncentrációt $\left(\mathrm{IC}_{50}\right)$ az egyenlet extrapolálásával, ahol $\log [\mathrm{S} 0 / \mathrm{S}-1]=\log [1]=0$ (Stephanson és mtsai. 2003). A mérést egy erős • OH kioltó hatású vegyülettel, etilalkohollal hasonló módon elvégezve szintén meghatároztuk az $\mathrm{IC}_{50}$ értéket, majd a levelek •OH antioxidáns kapacitását friss súlyra vonatkoztatva etil-alkohol ekvivalensekben fejeztük ki ( $\mu \mathrm{M}$ EtOH ekv. $\left.\mathrm{g}^{-1}\right)$. Fontos megjegyezni, hogy az etil-alkohol ${ }^{\circ} \mathrm{OH}$ kioltó hatása miatt ez a módszer csak vizes levélkivonatok mérésére alkalmas.

\subsubsection{Szinglett oxigén kioltó képesség mérése}

A méréshez a ${ }^{1} \mathrm{O}_{2}$-t fényérzékenyített reakcióban állítják elő, a metilkék (methylene blue, MB) festék megvilágításának hatására II. típusú fotodinámiás reakcióban, ahol a triplett gerjesztési állapotú festék az energiáját a molekuláris oxigénnek adja át (Halliwell és Gutteridge 1999). A fenti reakcióban keletkező ${ }^{1} \mathrm{O}_{2}$ mennyiségét egy indikátorvegyület színváltozása alapján mérjük, majd az antioxidáns-tartalmú növényi kivonat specifikus szinglett oxigén kioltóképességét a kifakításos reakció gátlása alapján határozzuk meg.

A fenti, általános eljárás többféle indikátorfestékkel is megvalósítható. Vizes levélkivonatok mérésére Kraljic és El Moshni (1978) szinglett oxigén detektálási módszerét alkalmaztuk, melyben a festék kifakítása egy köztiterméken keresztül valósul meg. Az RNO ( $p$-nitrozo-dimetilanilin) nevü festék kifakítása egy transz-gyürüs peroxid köztitermékkel való szelektív reakcióján alapul, ami a ${ }^{1} \mathrm{O}_{2}$ és egy imidazol gyürüs vegyület (itt a hisztidin) reakciójából képződik. ${ }^{1} \mathrm{O}_{2}$-kioltó antioxidáns (vagy ilyet tartalmazó növényi kivonat) hozzáadásával az RNO kifakulása gátolható, ami a festék abszorpciójának mérésével (440 nm) követhető nyomon. Alkoholos kivonatok vizsgálatára egyszerübb módszer a DFBF (1,3-difenil-izobenzofurán), egy vízben korlátozott 
oldhatóságú festék használata. A DFBF közvetlenül és specifikus módon lép reakcióba a szinglett oxigénnel, endoperoxid-gyürüt képezve (Carloni és mtsai. 1993), miközben abszorpciója csökkenése 410 nm-en követhetö.

A reakcióelegy a vizes kivonatok esetében $50 \mu \mathrm{M}$ MB-t, $25 \mu \mathrm{M}$ RNO -t és $10 \mathrm{mM}$ L-hisztidint tartalmazott (Sigma-Aldrich) semleges kémhatású Na-foszfát pufferben (50 mM, pH 7,0). $1 \mathrm{ml}$ reakcióelegyhez különböző mennyiségű (10-100 $\mu \mathrm{L})$ levélkivonatokat adva KL 1500 LCD lámpával (vörös szürő alkalmazásával, $\left.2500 \mu \mathrm{mol} \mathrm{m} \mathrm{m}^{-2} \mathrm{~s}^{-1} \mathrm{PAR}\right) 8$ perces megvilágítás előtt és után is mértük az abszorpciót (Shimadzu UV-1601). Alkoholos kivonatok (hárslevelek) esetében 50\%-os metanolban történt a mérés, ami $200 \mu \mathrm{M}$ MB-t és $1 \mathrm{mM}$ DFBF-et tartalmazott.

Egy minta több különböző koncentrációjú oldatával történő mérés alapján kiszámítottuk az 50\%-os inhibíciós koncentrációt. Ugyanilyen módon jártunk el a flavonol vegyületek (kvercetin, kempferol, miricetin, kvercetin-3-glükozid és kempferol-3glükozid, Sigma-Aldrich) esetében is. A mérést különböző Trolox koncentrációkkal (Sigma-Aldrich) ugyanígy elvégezve az $\mathrm{IC}_{50}$-et meghatároztuk, és a szinglett oxigén antioxidáns kapacitást levél friss vagy száraz súlyra vonatkoztatott Trolox ekvivalensekben fejeztük ki ( $\mathrm{IC}_{50}$ Trolox ekv. $\left.\mathrm{g}^{-1}\right)$.

\subsection{Hárslevél-kivonatok és flavonolok abszorpciós spektrumának felvétele}

A fagyasztva szárított hársleveleket 50\%-os metil-alkoholban homogenizáltuk, majd centrifugáltuk (10.000 g, 10 perc). A flavonoid vegyületeket (kvercetin, kempferol, miricetin, kvercetin-3- $\beta$-D-glükozid és kempferol-3-glükozid, Sigma-Aldrich) 50\%-os metil-alkoholban oldottuk és szürtük. A felülúszók abszorpciós spektrumát Shimadzu UV1601 spektrofotométer segítségével határoztuk meg.

\subsection{Hárslevelek flavonol aglükon tartalmának meghatározása}

A levelek flavonol aglükon tartalmát HPLC-DAD-ESI-MS/MS módszerrel mértük Schmidt és mtsai. (2010) leírása szerint. A fagyasztva szárított levelekből a flavonolok és glükozid-részük elválasztásához savas hidrolízissel készítettük a kivonatokat, 0,5 mg mennyiséget $50 \%$-os metanolban oldva, majd 2 órán át $1,6 \mathrm{M} \mathrm{HCl}$ hozzáadásával $90^{\circ} \mathrm{C}$ hőmérsékleten történő forralással. Az oldatokat 100 ml-re egészítettük ki 50\%-os metanol hozzáadásával, majd 5 perces szonikálást követően $0,45 \mu \mathrm{m}$ PTFE filteren át szürtük. 
A flavonol aglükon koncentráció meghatározását HPLC készülékkel (1100 modell, Agilent, Waldbronn, No.) végeztük. A metanolos kivonatokat Prodigy oszlopon (ODS 3, 150 x 3,0 mm, $5 \mu \mathrm{m}, 100 \AA$, Phenomenex, Aschaffenburg, No.) választottuk el, $25^{\circ} \mathrm{C}$ hömérsékleten, víz/acetonitril gradiensen. Az A oldat tartalma 99,5\% víz és 0,5\% ecetsav, a B oldaté 100\% acetonitril volt. A következő gradienst használtuk: 30-35\% B (5 perc), 35 $39 \%$ B (12 perc), 39-90\% B (5 perc), 90\% B izokratikus (5 perc), 90-30\% B (5 perc), 30\% B izokratikus (5 perc). Az áramlás percenként $0,3 \mathrm{ml}$ nagyságú volt, a DAD detektor által mért hullámhossz pedig $370 \mathrm{~nm}$. A kvercetin, kempferol és miricetin flavonoidokat deprotonált ionjaik és jellemző fragmentumaik alapján azonosítottuk HPLC-DAD-ESIMS/MS módszerrel, Agilent 1100 MSD iocsapda segítségével, ESI ionforrás felhasználásával negatív ionizációs módban. Nitrogént használtunk száraz (12 1/perc, $350^{\circ} \mathrm{C}$ ) és porlasztó gázként (40 psi). Az ioncsapdában hélium alkotta a robbanógázt. A tömegmeghatározást kvercetinre optimalizáltuk [M-H] - m/z 301. A csúcsokhoz tartozó koncentrációk meghatározásához a kalibrációkat a kereskedelmi forgalomban kapható, HPLC tisztaságú flavonoid standardok oldataival (0,5-10 mg $100 \mathrm{ml}^{-1}$, kvercetin, kempferol és miricetin, Carl Roth $\mathrm{GmbH}$, Karlsruhe, No.) végeztük. A méréseket két technikai ismétléssel végeztük.

\subsection{Felhasznált statisztikai módszerek}

Az átlagok és szórások kiszámítása Microsoft Office Excel 2003 (Microsoft Corporation) szoftverrel történt. A grafikonok elkészítéséhez és a Paerson-féle korrelációs együtthatók kiszámításához a SigmaPlot 12 szoftvert vettük igénybe (Systat Software Inc., San Jose, CA, USA). A t-próbák elvégzéséhez a GraphPad QuickCalcs online programot használtuk (GraphPad Software Inc., La Jolla, CA, USA), ahol a p < 0,05 konfidenciaszinten való átlag különbségeket tekintettük szignifikánsnak. 


\section{EREDMÉNYEK ÉS MEGVITATÁSUK}

\section{1. Általános és ROS-specifikus antioxidáns kapacitás próbák alkalmazhatósága a levelek fiziológiai állapotának leírására}

A kísérletben, amely mintegy elökísérletül szolgált az antioxidáns-tartalom mint növényi akklimációt jellemző paraméter kérdéskörének vizsgálatához, üvegházban stresszmentes körülmények között nevelt dohányról választottunk ki különböző korú leveleket (L1-L7), majd ezeket elemeztük fotoszintetikus teljesítmény és általános, valamint ROS-specifikus antioxidáns kapacitások tekintetében. Az eredményeket a 4. ábra mutatja. A klorofill fluoreszcencia méréssel meghatározott effektív fotokémiai hatékonyság (Y YSII-55) - ahogy az várható volt - fokozatos csökkenést mutatott a levelek korával: a legfiatalabb levélé (L1) az aktív fotoszintézisű növényi részekre jellemző 0,6 volt, míg a már a szeneszcencia előrehaladott stádiumában levő legidősebb levélé (L7, teljesen megsárgult levél alig detektálható klorofilltartalommal) csak 0,1 körüli (4.A ábra). A karotenoidok fokozatosan lebomlottak a levelek korának előrehaladtával (4.B ábra). A vizes kivonatokból mért három TAC paraméter (TEAC, FRAP, TFT) hasonló tendenciákat mutatott: a fiatalabb levelekben alacsony volt az értékük, majd egy maximális értéket elérve (L4 és L6 között) már nem növekedtek tovább a levelek korával (4.C-E ábra). A ROS-specifikus antioxidáns kapacitások közül itt a levélkivonatok ${ }^{\circ} \mathrm{OH}$ és $\mathrm{O}_{2}{ }^{\bullet-}$ semlegesítő képességét vizsgáltuk. Ahogy a 4.F és G ábrán látható, ezek a paraméterek nem követtek semmilyen jól látható tendenciát a levél korával összefüggésben.

A szeneszcencia mint egy természetes, ROS-képződéssel és oxidatív stresszel járó fiziológiai állapot (Zimmermann és Zentgraf 2005) kiváló rendszerül szolgált számunkra, hogy azonos növény különböző antioxidáns-tartalmú levelei segítségével az egyes antioxidáns kapacitások egymással és a fiziológiai állapottal való összefüggéseit vizsgálhassuk. A paraméterek korrelációit a Pearson-féle korrelációs koefficiens $\left(\mathrm{R}_{\mathrm{P}}\right)$ segítségével elemeztük, ahogy azt az 1. táblázat mutatja. Szorosabb összefüggést csak néhány paraméter között találtunk (ahol az $R_{P}$ abszolút értéke nagyobb mint 0,8 a táblázatban vastag betűs kiemelés jelzi). A fotokémiai hatékonyság, mint a levelekre jellemző fontos fiziológiai mutató, szoros korrelációt csak a karotenoidtartalommal, illetve a TEAC paraméterrel mutatott. Míg a karotenoidtartalommal a lineáris összefüggés pozitív volt $\left(R_{P}=0,85\right)$, addig a TEAC paraméterrel fordított összefüggést találtunk $\left(R_{P}=-0,91\right)$. 

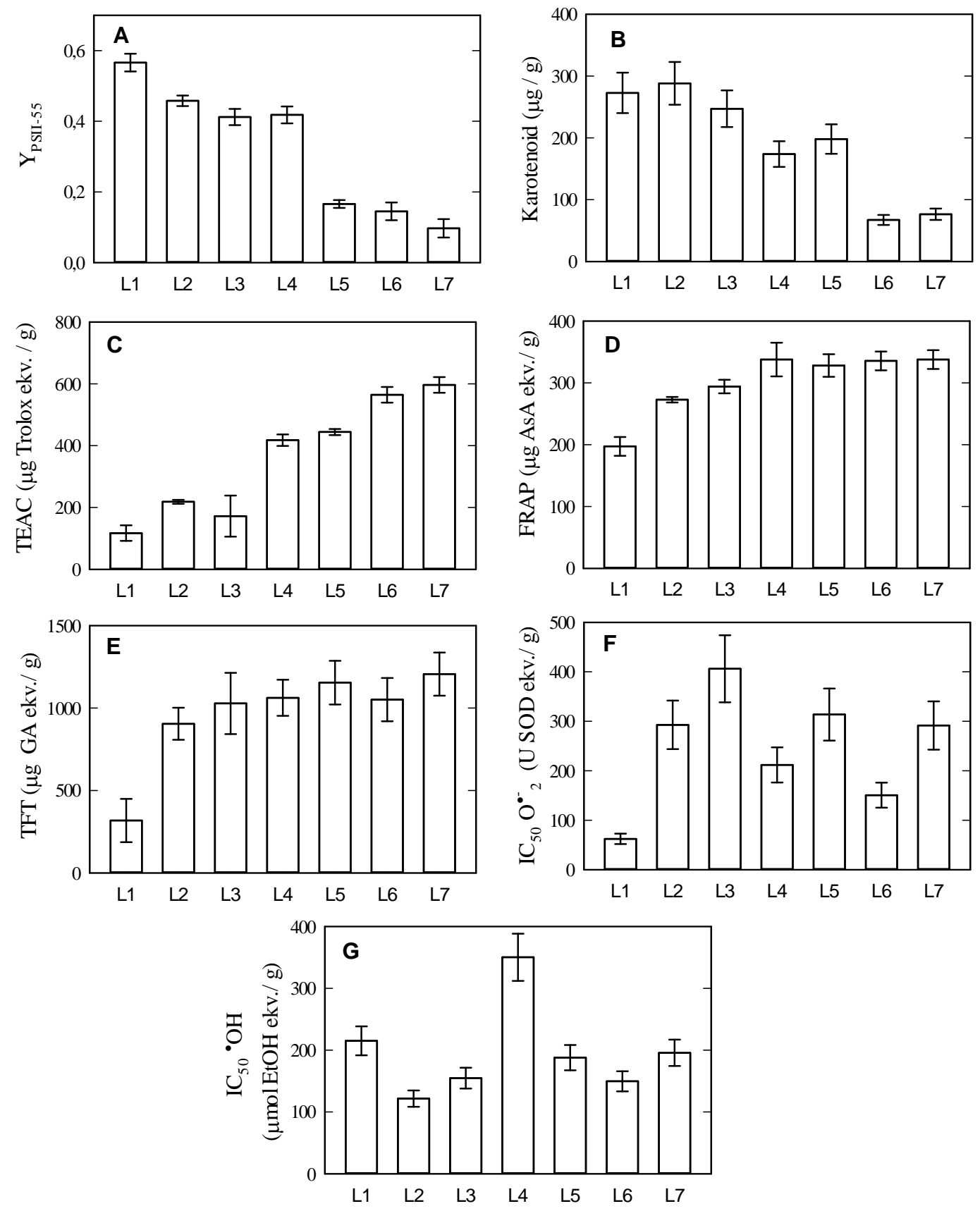

4. ábra: Üvegházban nevelt dohány különböző korú leveleinek (L1-L7, koruk szerint növekvő sorrendben) fotokémiai hatékonyság (A), karotenoidtartalom (B) és TAC (C-E), valamint ROS specifikus antioxidáns kapacitás ( $\mathrm{F}-\mathrm{G})$ értékei $(\mathrm{N}=3, \pm \mathrm{SD})$. 
1. táblázat: Összefüggések üvegházban nevelt dohány különböző korú leveleinek fotokémiai hatékonysága, karotenoidtartalma, valamint TAC és SAC értékei között $(\mathrm{N}=3, \pm \mathrm{SD})$. Az összefüggések erősségét a Pearson-féle korrelációs együtthatóval $\left(R_{P}\right)$ jellemeztük. Ahol $\left|R_{P}\right|>0,8$, a táblázatban vastag betüs kiemelés jelzi.

\begin{tabular}{|lrrrrrrr|}
\hline $\mathbf{R}_{\mathbf{P}}$ & $\mathrm{Y}_{\text {PSII }}$ & \multicolumn{1}{c}{ Kar } & \multicolumn{1}{c}{ TEAC } & \multicolumn{1}{c}{ FRAP } & \multicolumn{1}{c|}{$\mathrm{TFT}$} & $\mathrm{IC}_{50} \mathrm{O}_{2}{ }^{-}$ & $\mathrm{IC}_{50}{ }^{\circ} \mathrm{OH}$ \\
$\mathrm{Y}_{\text {PSII }}$ & 1 & $\mathbf{0 . 8 5}$ & $-\mathbf{0 . 9 1}$ & -0.78 & -0.76 & -0.25 & 0.18 \\
$\mathrm{Kar}$ & & 1 & $-\mathbf{0 . 9 4}$ & -0.74 & -0.59 & 0.10 & -0.12 \\
TEAC & & & 1 & $\mathbf{0 . 8 4}$ & 0.72 & 0.02 & 0.14 \\
FRAP & & & & 1 & $\mathbf{0 . 9 5}$ & 0.44 & 0.18 \\
$\mathrm{TFT}$ & & & & & 1 & 0.67 & -0.01 \\
$\mathrm{IC}_{50} \mathrm{O}_{2}{ }^{-}$ & & & & & & 1 & -0.29 \\
$\mathrm{IC}_{50}{ }^{\circ} \mathrm{OH}$ & & & & & & & 1 \\
\hline
\end{tabular}

Maga a karotenoidtartalom és a TEAC igen szoros negatív lineáris kapcsolatban állt egymással a vizsgált rendszerben $\left(\mathrm{R}_{\mathrm{P}}=-0,94\right)$. A TAC paraméterek egymással való korrelációját elemezve azt találtuk, hogy a TEAC és a FRAP $\left(R_{P}=0,84\right)$, illetve a FRAP és a TFT mutatott összefüggést, az utóbbi szorosabbat $\left(R_{P}=0,95\right)$. A ROS-specifikus antioxidáns paraméterek nem korreláltak ebben a kísérleti rendszerben egyetlen további mért jellemzővel sem.

Eredeményeink összhangban vannak azzal az ismert megfigyeléssel, mely szerint a szeneszcencia során az antioxidánsok aktivitása növekszik, viszont ez a növekedés rendszerint nem tud lépést tartani a prooxidánsokéval, és ez okozza az abiotikus környezeti hatásokhoz hasonló oxidatív károsodást (Zimmermann és Zentgraf 2005; Khanna-Chopra 2012). A mi eredményeink is azt mutatják, hogy a levelek korával csak a szeneszcencia egy bizonyos fokáig (L4-L6) nőnek a különböző TAC paraméterek értékei, miközben a Y PSII-55 további csökkenése az idősebb leveleknél a fotoszintetikus rendszer degradációját mutatja. Egyes összefüggések további elemzését segítendő, ezeket grafikusan is ábrázoltuk (5. ábra). Ebből láthatjuk, hogy a FRAP és TFT paraméterek nem lineáris módon függtek össze a Y YSII élettani mutatóval (5.A-B ábra). Habár a TEAC értékeinek szorosabb (lineárisabb) negatív korrelációja volt a fotokémiai hatékonysággal (5.C ábra), az ezzel a módszerrel mérhető antioxidáns vegyületek úgy tűnik, mégsem voltak képesek elég védelmet nyújtani az oxidatív stresszel szemben a szeneszcencia elörehaladtával.

A karotenoid pigmentek - amelyek mind fotoszintetikus, mind védőpigmentek szerepét betöltik (Demmig-Adams és Adams 1993) és egyben antioxidáns hatású molekulák is (Norman és Krinsky 1989) - mennyiségének szoros korrelációja a fotokémiai 
hatékonysággal (1. táblázat) utalhat antioxidáns szerepükre, azonban a TEAC paraméterrel való negatív összefüggés arra mutat rá, hogy a karotenoidok szerepét a levelek korának előrehaladtával más, a TEAC próbával a karotenoidoknál reaktívabb antioxidánsok vették át. Másrészről, ahogy Miller és mtsai. (1996) kimutatták, az egyes karotenoidok is különböző TEAC értékekkel rendelkeznek, pl. a karotinoké magasabb mint a xantofilloké. A szeneszcencia során kimutatható, hogy a karotinok gyorsan lebomlanak, míg a $\left({ }^{1} \mathrm{O}_{2}\right.$ védelemben is szerepet játszó) xantofill-ciklus vegyületei kisebb mértékben és lassabban degradálódnak (Keskitalo és mtsai. 2005). Ezen kívül azt is érdemes megjegyezni, hogy a vizes levélkivonatokkal végzett TEAC teszt valójában a karotenoidoknak csak egy részét mutatja ki (Arnao 2000).
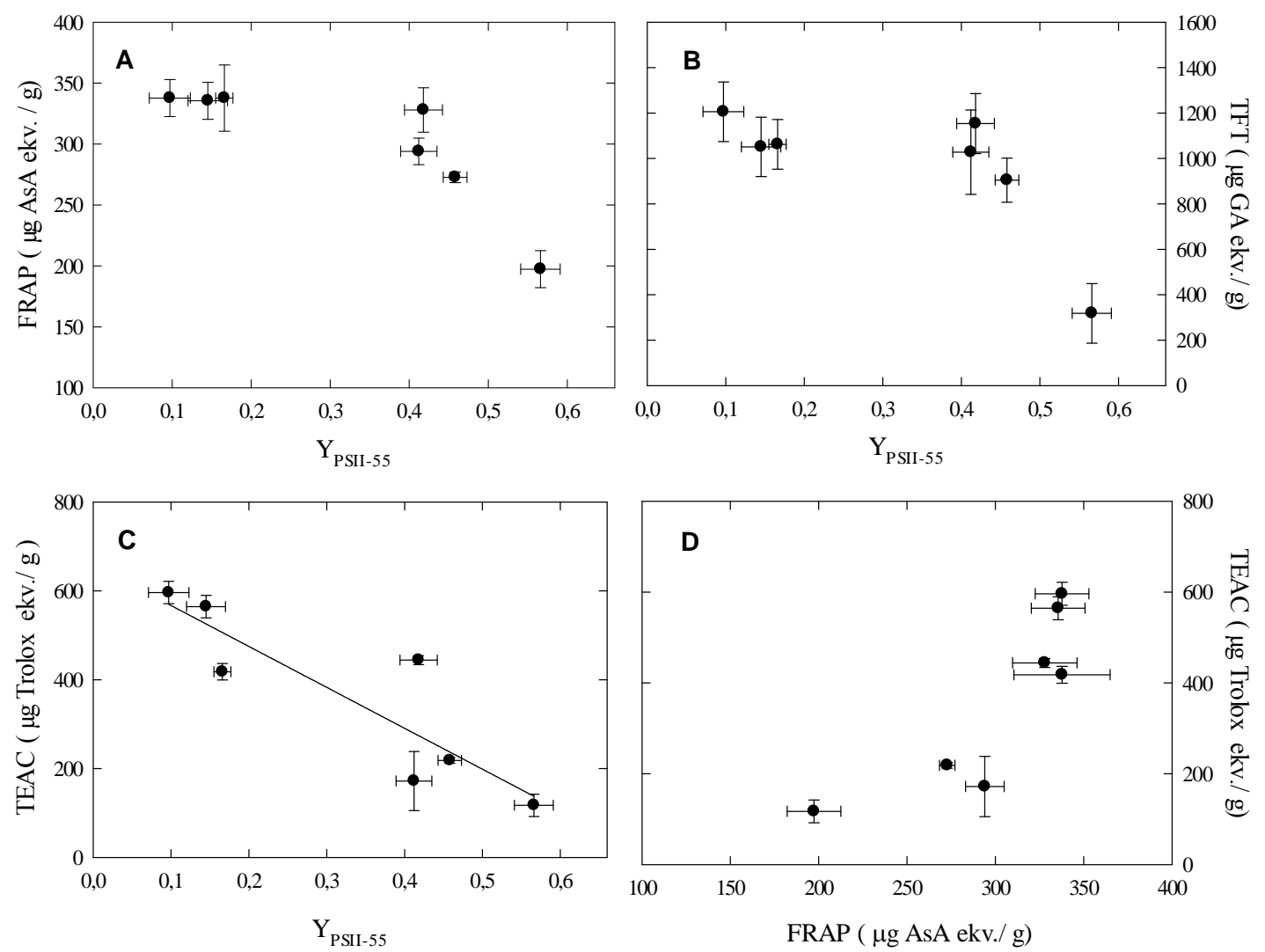

5. ábra: Összefüggések üvegházban nevelt dohány különböző korú leveleinek (L1-L7) fotokémiai hatékonysága és TAC értékei között (A-C), illetve két TAC paramétere között (D). 
A különböző TAC paraméterek egymással való viszonylag jó korrelációja megerősítette azt a megállapítást, hogy az ET-alapú antioxidáns tesztek általában hasonló eredményeket adnak, mivel lényegében mind egy kivonat redukálóképességét mérik (Huang és mtsai. 2005). Másrészt a TEAC és a FRAP (vagy a TFT) értékei (5. D ábra) nem lineáris módon függtek össze. A TEAC teszt nagyobb érzékenységét az antioxidáns változásokra mutatja az, hogy a legfiatalabb (L1) és az L6-L7 levelek értékei között csaknem 5-szörös különbségeket tudtunk kimérni ezzel a módszerrel. Ahogy Apak és mtsai. (2007) összefoglaló tanulmányukban felhívják rá a figyelmet, még az azonos alapon müködő (ET) tesztek eredményei között is lehetnek nagy különbségek a redoxpotenciáltól és az oldattól függően, így valójában mindig hasznos lehet megvizsgálni a korrelációkat a különböző TAC paraméterek között.

A mi kísérleti rendszerünkben, vagyis a természetes szeneszcencia összefüggésében, nem mutattak a vizsgált specifikus antioxidáns kapacitások semmilyen mintázatot. Ez egyrészt jelentheti azt, hogy az adott folyamatban nem a $\mathrm{O}_{2}{ }^{{ }^{-}}$, illetve a ${ }^{\bullet} \mathrm{OH}$ a legfontosabb mediátorok, másrészt eredhet az antioxidánsok müködésének már fentebb említett redundáns jellegéből. Az előbbi feltételezést erősíti a SAC paraméterek TAC mutatókkal való összefüggéseinek hiánya is. Zentgraf és Hemleben (2008) elsősorban a $\mathrm{H}_{2} \mathrm{O}_{2}$ jelentőségét hangsúlyozzák, mint a szeneszcenciában legfontosabb szereppel bíró (jelátvivő) ROS formát, de a folyamatban valószínűleg más $\mathrm{ROS}-\mathrm{ok}\left(\mathrm{O}_{2}{ }^{--},{ }^{\circ} \mathrm{OH},{ }^{1} \mathrm{O}_{2}\right)$ is részt vesznek (Van Breusegem és Dat 2006)

Miután különböző korú és fiziológiai állapotú dohánylevelekkel mint modellrendszer segítségével megmutattuk, hogy a különböző TAC próbák párhuzamos alkalmazása érzékenyen mutatja az antioxidánsok változásait, áttértünk ezek UVakklimációban játszott jelentőségének felderítésére. A következő kísérletben a különbözü korú, szeneszcencia jegyeit még nem mutató (azonos klorofilltartalmú) és eltérő antioxidáns viszonyokkal jellemezhető levelek UV-fényhez való akklimációját vizsgáltuk.

\subsection{Eltérő antioxidáns-tartalmú fiatalabb és idősebb levelek akklimációs válaszai kiegészítő UV-sugárzásra üvegházi kísérletben}

Az UV-sugárzáshoz való akklimáció antioxidáns alapjainak vizsgálatához egy nemes szőlőfajta, a Chardonnay különböző korú leveleit választottunk modellként. Ebben a kísérletben a szeneszcencia jegyeit még nem mutató kifejlett leveleket vizsgáltuk (ahol a fiatal és idős levelek között nem volt klorofilltartalom tekintetében különbség). Ez az indás 
kúszónövény ideális volt arra, hogy vesszőit egy vízszintesen fekvő rácsra hajtatva fiatalabb és idősebb (már kifejlett de még nem szeneszcens) színükkel egyaránt felfele mutató leveleit azonos dózisú UV-besugárzásnak tegyük ki. A növények egy része az üvegházi látható fény (50 $\mu \mathrm{mol}$ foton $\mathrm{m}^{-2} \mathrm{~s}^{-1}$ PAR) mellett $8,95 \mathrm{~kJ} \mathrm{~m}^{-2} \mathrm{~d}^{-1}$ kiegészítő UV (UV-B központú) sugárzást is kapott a kísérlet négy napján keresztuil. Ezután az UV-kezelt és kezeletlen növények fiatalabb és idősebb levelein is elvégeztük a fotoszintézis $\left(\mathrm{CO}_{2}\right.$ megkötés) és fotokémiai hatékonyság méréseket, majd a levelek kivonataiból meghatároztuk a TAC és SAC értékeket.

Ahogyan az 6. ábra mutatja, a csak látható fényen tartott (PAR) növényeknél a fotokémiai hatékonyság ( $\left.\mathrm{Y}_{\mathrm{PSII}-55}\right)$ tekintetében az idősebb levelek (IL) magasabb értékeket mutattak, mint a fiatal levelek (FL). Az UV-kezelés (PAR+UV) viszont eltéröen hatott a két csoportra: az előbbinél 44, az utóbbinál 22\%-kal csökkentve a fényadaptált fotokémiai hatékonyságot (6.A ábra). A potenciális (maximális) fotokémiai hatékonyság $\left(\mathrm{F}_{\mathrm{v}} / \mathrm{F}_{\mathrm{m}}\right)$ kezelés nélkül a fiatal és idős leveleknél azonos volt, de az UV-besugárzásra ennek a mutatónak az esetében is az idős levelek reagáltak érzékenyebben (20 illetve 37\%-os csökkenés, 6.B ábra). A növények levelein a nevelési fénynél magasabb (300 $\mu$ mol foton $\mathrm{m}^{-2} \mathrm{~s}^{-1}$ ) PAR-on végzett gázcsere analízis megmutatta, hogy az alkalmazott UV-dózis megfelelö erősségü volt ahhoz, hogy szignifikáns mértékü csökkenést okozzon a fotoszintetikus $\mathrm{CO}_{2}$-megkötésben, mind a $\mathrm{FL}$, mind az IL esetében (6.C ábra). A sztómakonduktancia az UV hatására szintén hasonlóan szignifikánsan lecsökkent (az adatok itt nincsenek bemutatva).

A levelek vizes kivonataiban mértük a TAC és SAC paramétereiket. Az UV kezelés hiányában (PAR növények) a TFT és a TEAC nagyjából feleakkora (57 illetve $51 \%$ ) volt a fiatal levelek esetében az idősekhez viszonyítva, míg a FRAP értékében nem volt szignifikáns különbség a levél korának hatására. Az UV-kezelésben részesült növények FL mintáiban mindhárom TAC paraméter megnövekedett (leghangsúlyosabb a TEAC esetében megfigyelt 3-szoros növekedés volt), míg az UV-kezelt IL értékei a kezeletlen IL-éhez közeliek maradtak (6.D-F ábra). A specifikus ROS-kioltást itt a hidroxilgyök és szinglett oxigén vonatkozásában vizsgáltuk. Elöbbit az indokolja, hogy •OH közvetlenül is megfigyelhető volt a jelenleg alkalmazottnál nagyobb dózisú UV kezelés hatására (Hideg és Vass 1996). A ${ }^{1} \mathrm{O}_{2}$ keletkezés ugyan nem jellemző UV-B kezelt levelekre közvetlen hatásként, az UV által meggyengített fotoszintézisü mintákban azonban megjelenhet (Hideg és mtsai 2000). A TAC paraméterek válaszaihoz hasonlóan az UV-kezelés szintén csak a FL esetében okozott növekedést: a hidroxilgyök-kioltásban 
kisebb (30\%-os, 7.A ábra), míg a ${ }^{1} \mathrm{O}_{2}$ semlegesítésben igen jelentős (7-szeres) mértéküt (7.B ábra). $\mathrm{Az}{ }^{\circ} \mathrm{OH}$ antioxidáns kapacitás a kezeletlen IL esetében magasabb volt a FL értékeihez képest.
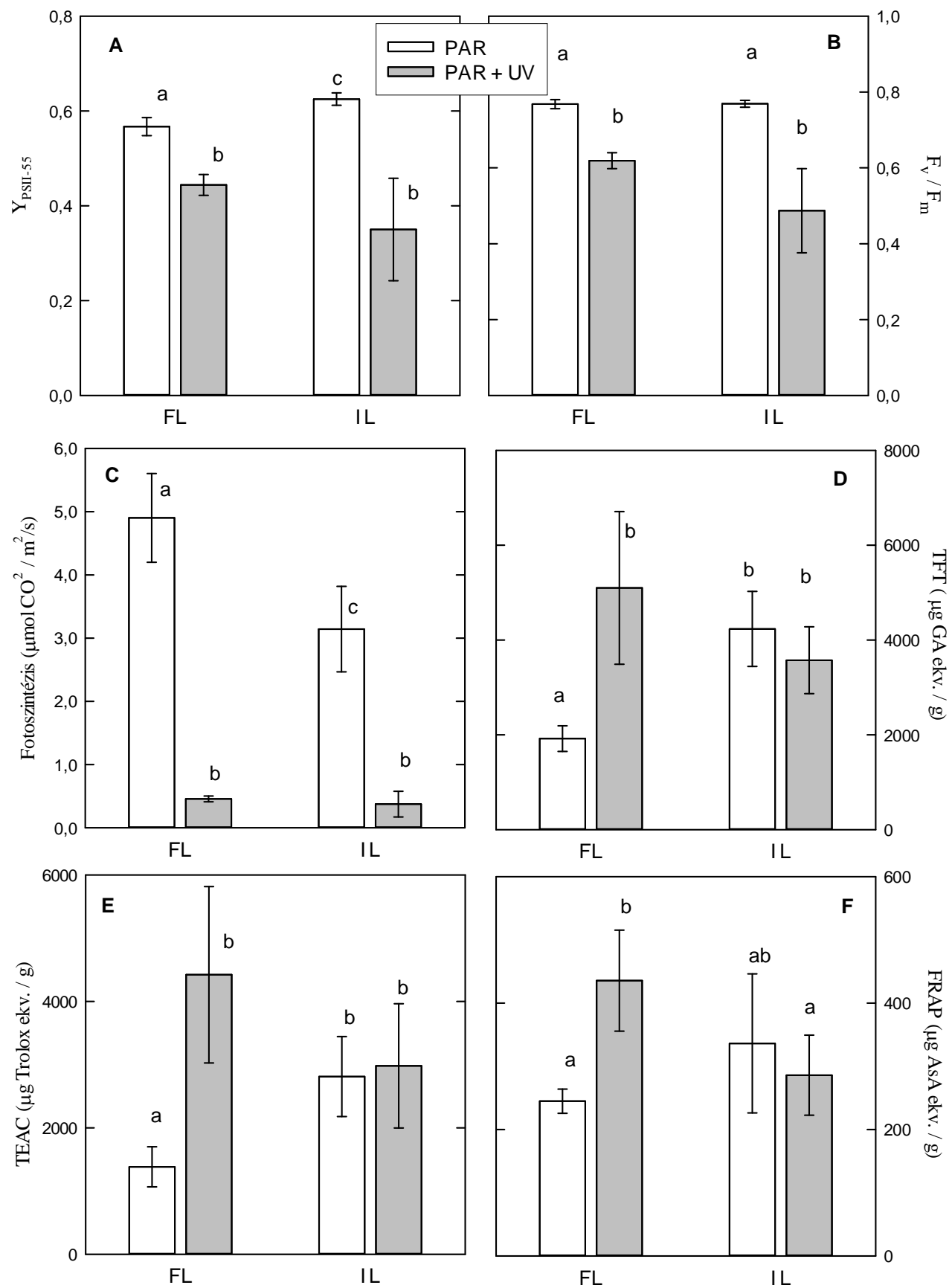

6. ábra: Üvegházi kísérletben látható fényen nőtt (PAR) és kiegészitő UV-sugárzás kezelésben $(\mathrm{PAR}+\mathrm{UV})$ részesült szőlő fiatal $(\mathrm{FL})$ és idős leveleinek (IL) fényadaptált (A) és maximális fotokémiai hatékonysága (B), fotoszintézise (C), valamint TAC értékei (D-F). Az oszlopok feletti azonos betűk az átlagok egyezését mutatják $\mathrm{p}<0,05$ konfidenciaszinten $(\mathrm{N}=3-9, \pm \mathrm{SD})$ 
Mivel az UV-kezelésre adott válasz gyakran magában foglalja az ezen a hullámhosszon abszorbeáló fényvédő pigmentek megemelkedett mértékü szintézisét is (Jansen és mtsai. 1998), megmértük a kivonatok 280 és 315 nm közötti abszorpciójának változásait (7.C. ábra). A mérés azt mutatta, hogy a FL esetében a 4-napos UV-kezelés hatására valóban történt egy nagymértékü, 74\%-os növekedés, azonban az IL esetében nem figyeltünk meg ilyet. Az UV-kezelés hiányában az IL-t a FL-hez képest egy magasabb szintü UV-B abszorpció jellemezte, ami nagyjából megegyezett az UV-kezelt levelek (FL és IL) ezen értékeivel. Karotinoidok tekintetében a FL és IL között nem volt különbség, és az UV csak az IL esetében okozott egy kis mértékü (15\%-os) növekedést ezekben a pigmentekben (7.D. ábra). Ebben a kísérletben is vizsgáltuk a különböző paraméterek összefüggéseit (2. táblázat). A szorosabb korrelációkat ( $\left.\left|R_{P}\right|>0,8\right)$ a táblázatban vastag betüs kiemeléssel jelöltem és az alábbiakban tárgyalom.
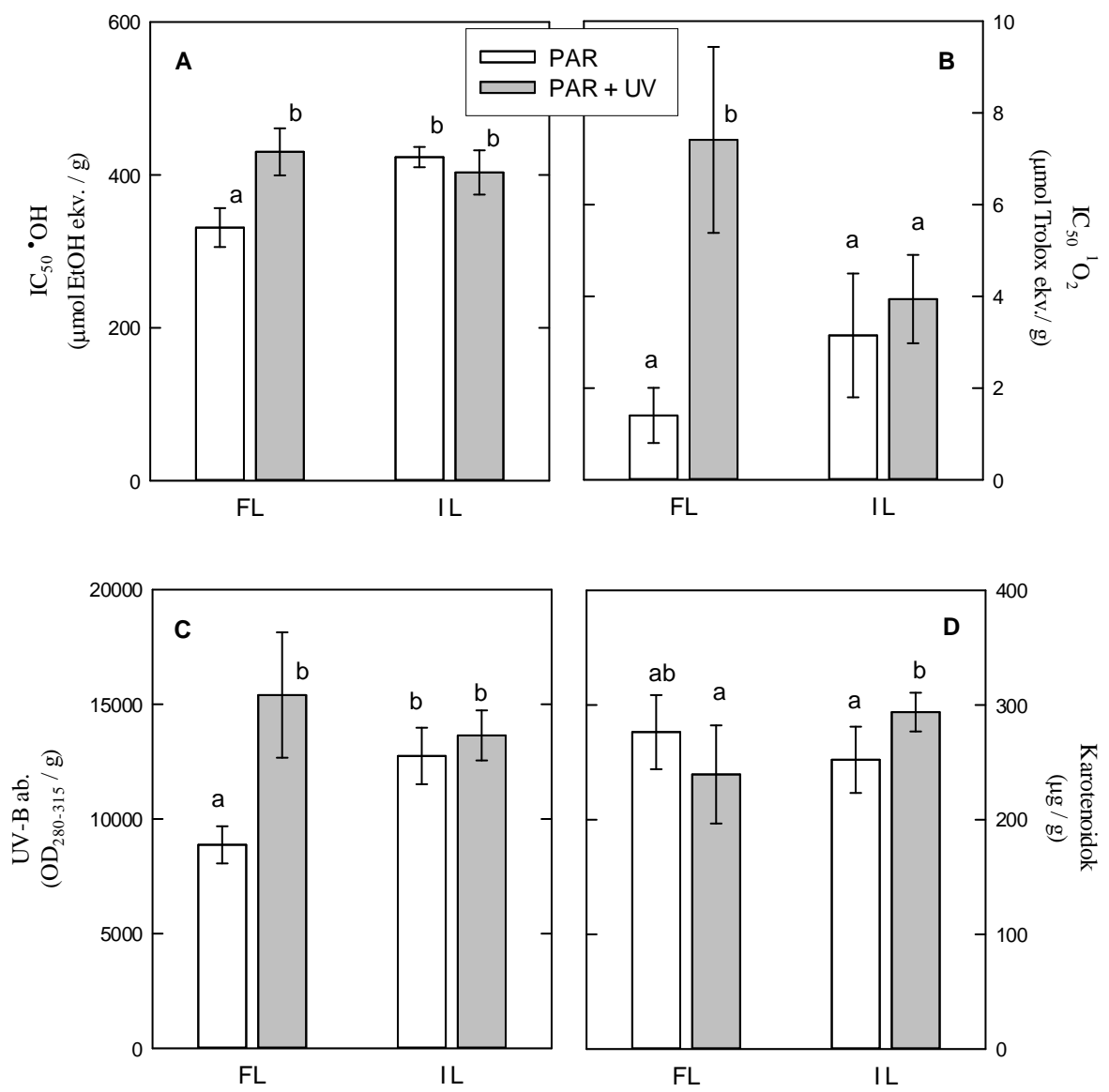

7. ábra: Üvegházi kísérletben látható fényen nőtt (PAR) és kiegészitő UV-sugárzás kezelésben $(\mathrm{PAR}+\mathrm{UV})$ részesült szőlő fiatal (FL) és idős leveleinek (IL) SAC paraméterei (A-B), UV-B abszorbeáló pigmentjei (C) és karotenoidtartalma (D). Az oszlopok feletti azonos betúk az átlagok egyezését mutatják $\mathrm{p}<$ 0,05 konfidenciaszinten $(\mathrm{N}=3-9, \pm \mathrm{SD})$. 
2. táblázat: Összefüggések látható fényen nőtt és kiegészítő UV-sugárzás kezelésben részesült szőlő fiatal és idős leveleinek fotokémiai hatékonyság jellemzői, fotoszintézise, karotenoidtartalma, UV-B abszorbeáló pigmentjei, valamint TAC és SAC értékei között. Az összefüggések erősségét a Pearson-féle korrelációs együtthatóval $\left(R_{P}\right)$ jellemeztük. Ahol $\left|R_{P}\right|>0,8$, a táblázatban vastag betűs kiemelés jelzi.

\begin{tabular}{|c|c|c|c|c|c|c|c|c|c|c|}
\hline $\mathbf{R}_{\mathbf{P}}$ & $\mathrm{Y}_{\text {PSII }}$ & $\mathrm{F}_{\mathrm{v}} / \mathrm{F}_{\mathrm{m}}$ & Fot & Kar & TEAC & FRAP & TFT & $\mathrm{IC}_{50}{ }^{1} \mathrm{O}_{2}$ & $\begin{array}{l}\mathrm{IC}_{50} \\
{ }^{\circ} \mathrm{OH}\end{array}$ & $\begin{array}{c}\text { UV-B } \\
\text { ab }\end{array}$ \\
\hline $\mathrm{Y}_{\mathrm{PSII}}$ & 1 & 0.98 & 0.87 & -0.41 & -0.49 & 0.00 & -0.31 & -0.40 & -0.36 & -0.61 \\
\hline $\mathrm{F}_{\mathrm{v}} / \mathrm{F}_{\mathrm{m}}$ & & 1 & 0.82 & -0.41 & -0.46 & 0.00 & -0.22 & -0.40 & -0.23 & -0.53 \\
\hline Fot & & & 1 & 0.07 & -0.85 & -0.47 & 0.73 & -0.76 & -0.74 & -0.92 \\
\hline Kar & & & & 1 & -0.59 & -0.91 & -0.68 & -0.67 & -0.54 & -0.43 \\
\hline TEAC & & & & & 1 & 0.86 & 0.95 & 0.98 & 0.88 & 0.97 \\
\hline FRAP & & & & & & 1 & 0.87 & 0.92 & 0.73 & 0.74 \\
\hline TFT & & & & & & & 1 & 0.90 & 0.97 & 0.94 \\
\hline${ }^{1} \mathrm{O}_{2} \mathrm{AC}$ & & & & & & & & 1 & 0.77 & 0.90 \\
\hline${ }^{\circ} \mathrm{OH} \mathrm{AC}$ & & & & & & & & & 1 & 0.93 \\
\hline UV-B ab & & & & & & & & & & 1 \\
\hline
\end{tabular}

A fenti eredmények megvitatásakor fontos megjegyezni, hogy bár az alkalmazott UV dózis csak kevéssel volt magasabb, mint a földrajzi szélességünknek megfelelö átlagos napi dózis nyáron (7,5 $\mathrm{kJ} \mathrm{m}^{-2}$ BED UV-B, Bassmann és mtsai. 2001), a kezelés mégis jelentősen limitálta a levelek fotoszintézisét. Ennek magyarázata egyrészt az, hogy üvegházban, UV-mentes környezetben nevelt növényt vizsgáltunk, másrészt az, hogy a PAR:UV arány a kísérletben a természetesnél sokkal alacsonyabb volt. A PAR szintek módosító hatását az UV-B válaszokra több tanulmány is tárgyalja (pl. Berkelaar és mtsai. 1994; Sicora és mtsai. 2003; Krizek és mtsai. 2004). Azonban még ez a 4-napos UVkezelés okozta stressz sem járt fotoszintetikus pigmentveszteséggel és a hatása visszafordítható volt (az adatok itt nincsenek bemutatva). A maximális $\left(\mathrm{F}_{\mathrm{v}} / \mathrm{F}_{\mathrm{m}}\right)$ és effektív (Y $\left.Y_{\mathrm{PSII}-55}\right)$ fotokémiai hatékonyság közötti erős korreláció $\left(\mathrm{R}_{\mathrm{P}}=0,98\right)$, illetve a két értéknek a $\mathrm{CO}_{2}$-fixációval való összefüggései) arra utalnak, hogy az UV-indukálta fotoszintézisgátlásért csak részben a sztómakonduktancia csökkenése volt a felelös (amely folyamatban szintén szerepet játszanak a ROS-ok), és részt vehettek benne a PS II közvetlen gátlási folyamatai (feltehetően ROS-indukált degradációja) is. Az UV-B sugárzásról kimutatták, hogy elsősorban a sztómanyitás gátlásán keresztül fejti ki fotoszintézis-gátló hatását (Nogues és mtsai. 1999; Jansen és van den Noort, 2000), de bizonyított az UV indukálta gátlás az elektrontranszportban (Vass és mtsai. 1996) és a Rubisco-szintézisben is (Takeuchi és mtsai. 2002; Choi és Roh 2003). A Chardonnay szőlöfajta fotoszintézisének 
csökkenését UV-B besugárzás hatására korábban Bálo és mtsai. (1998) kimutatták. A mi kísérletünkban az UV-kezelés eredményeképp az IL esetén a fotokémia jelentősebb mértékben csökkent, mint a FL esetében. A levelek korának befolyását az UV-B válaszokra már korábban is kimutatták, például keresztesvirágú (Reifenrath és Müller 2007) vagy citrus fajok (Ibañez és mtsai. 2008) esetében, a levelek eltérő UV-abszorbeáló pigmentmennyiségének tulajdonítva a hatást. Szőlő levelekben az UV-B abszorbeáló pigmentek (fenolos vegyületek) szintézisének növekedését és az antioxidáns védekezési rendszer indukcióját is kimutatták UV-B hatásra (Pontin és mtsai. 2010; Berli és mtsai. 2010), azonban különböző korú levelek összehasonlítására nem ismertek irodalmi adatok.

A TAC paraméterekben UV indukálta növekedést csak a FL esetében figyelhettünk meg. Míg a a PAR növényeknél TEAC, a TFT, a FRAP, a `OH-kioltás és az UV-B abszorbancia értékei magasabbak voltak az IL, mint a FL esetében, addig az UV-kezelés hatására csak a FL mutattak megemelkedett szinteket. Ugyanakkor fotoszintézis méréseink azt mutatták, hogy a kezdettől fogva magasabb antioxidáns koncentrációjú IL nem rendelkeztek jobb UV-sugárzás türéssel, sőt, a fotokémiai hatékonyságukban jelentősebb csökkenést mutattunk ki, mint ami a FL esetében jellemző volt. Ebben a kísérletben a három mért TAC mutató hasonlóan viselkedett, így korrelációjuk is viszonylag szoros volt $\left(\mathrm{R}_{\mathrm{P}}>0,8,2\right.$. táblázat). A TEAC mutatta a legszorosabb korrelációt a két vizsgált $\mathrm{SAC}$ paraméterrel, ami arra utalhat, hogy az antioxidáns kapacitásbeli növekedés itt főként a •OH- és ${ }^{1} \mathrm{O}_{2}$-reaktív vegyületek felhalmozódásának volt tulajdonítható. Erre utal az is, hogy a FL esetén jelentős mértékü (7-szeres) ${ }^{1} \mathrm{O}_{2}$ antioxidáns-aktivitásbeli különbséget mérhettünk az UV-fény hatására. A ${ }^{\circ} \mathrm{OH}$ jelenlétét izolált tilakoidmembránokban magas UV-B dózissal történő besugárzás hatására Hideg és Vass (1996) kimutatták, ezzel szemben ${ }^{1} \mathrm{O}_{2}$-produkciót közvetlenül csak magasabb hullámhosszú UV-A sugárzás hatására tudtak kimutatni (Hideg és mtsai. 2002). A ${ }^{1} \mathrm{O}_{2}$ produkciója azonban megnövekedhetett a fotoszintetikus kapacitás UV-indukálta korlátozásának hatására. A karotenoidok - amelyek közül sok hatékony ${ }^{1} \mathrm{O}_{2}$-kioltó vegyület - mennyisége az IL-ben kis mértékben megnőtt az UV hatására, de nem mutatott korrelációt a specifikus ${ }^{1} \mathrm{O}_{2}$ antioxidáns kapacitással (2. táblázat). Az elsősorban nem UV, hanem PAR okozta stresszel összefüggésbe hozható ${ }^{1} \mathrm{O}_{2}$ semlegesítésének és az UV válaszok összefüggéseinek vizsgálatára a későbbiekben természetes napsugárzásnak kitett levelek vizsgálataival tértünk vissza (1. 5.4. fejezet).

A különböző korú levelek esetében az UV-B abszorbeáló pigmentek szintjének emelkedése és az UV-tolerancia között összefüggést mutattak ki keresztesvirágú-, illetve 
citrusfajok esetében (Reifenrath és Müller 2007, Ibañez és mtsai. 2008). Berli és mtsai. (2010) szőlőnél is kimutatta az UV-sugárzás hatását az ezen a hullámhosszon abszorbeáló pigmentek mennyiségének emelkedésére. Kolb és mtsai. (2001) vizsgálatai szerint szőlőnél az epidermiszben elhelyezkedő fényszürő pigmentek a PS II fotokémiát meg tudták védeni UV-B sugárzás káros hatásaitól, viszont a levelek $\mathrm{CO}_{2}$-megkötési képességében csökkenés mutatkozott. A mi kísérletünkben az UV-B abszorpció csak a FL esetében nőtt meg UVhatásra, és az IL-nél már eleve egy magasabb szinten volt. A TEAC, TFT és a két SAC paraméterrel való szorosabb összefüggés, illetve az a tény, hogy UV hatására sem halmozódtak fel nagyobb mennyiségben, mint amit az idősebb PAR leveleknél mérhettünk, arra utal, hogy ezek a pigmentek nem elsősorban az UV-sugarak abszorpcióján keresztül megvalósuló fényvédelemben, hanem inkább antioxidáns hatásuk miatt lehetnek jelentősek.

\subsection{Magas fény előkezeléssel kiváltott eltérő antioxidáns-tartalommal rendelkező levelek UV-akklimációja üvegházi kísérletekben}

Tovább vizsgálva a levelek eltérő antioxidáns-tartalmának szerepét az UVválaszokban, egy olyan kísérletet állítottunk be, ahol a kiegészítő UV-kezelés megkezdésekor fennálló antioxidáns kapacitásbeli eltéréseket nem egy belső faktor (a levelek kora), hanem egy külső tényező okozta. Ennek eléréséhez a $200 \mu \mathrm{mol}$ foton $\mathrm{m}^{-2} \mathrm{~s}^{-1}$ PAR fényen nevelt dohányok egy részét 6 hetes korban 5 napra magasabb (1000 $\mu$ mol foton $\left.\mathrm{m}^{-2} \mathrm{~s}^{-1} \mathrm{PAR}\right)$ fényre helyeztük, míg a többi növényt továbbra is az alacsony fényintenzitáson tartottuk. Ezután mind a magas (1000) mind az alacsonyabb fényen nevelt (200) csoportot $200 \mu \mathrm{mol}$ foton $\mathrm{m}^{-2} \mathrm{~s}^{-1}$ PAR megvilágítás alá helyeztük, de azokat további 2-2 részre bontva csak az egyiknél alkalmaztunk 8,95 $\mathrm{kJ} \mathrm{m}^{-2}$ BED napi dózisú kiegészítő UV-sugárzást. 6 napon át. A kezelések részletes leírását az Anyagok és módszerek fejezet tartalmazza. A kiegészítő UV kezelés utolsó napján mind a négy (200-PAR, 1000-PAR, 200-UV és 1000-UV) csoporton elvégeztük a gázcsere és klorofill fluoreszcencia analízist, ezután azok kivonataiból meghatároztuk a pigmenttartalmat és az antioxidáns kapacitásokat.

Az eredményeket a 8. ábra mutatja. A magas fényen történő előkezelésnek nem volt negatív hatása sem a $\mathrm{CO}_{2}$-megkötésre, sem a potenciális fotokémiai hatékonyságra $\left(\mathrm{F}_{\mathrm{v}} / \mathrm{F}_{\mathrm{m}}\right)$, ami a növények akklimációját mutatja a megváltozott fényviszonyokhoz. Az UV kezelés viszont különböző mértékben csökkentette a fotoszintetikus $\mathrm{CO}_{2}$-megkötési rátát 
az előkezelés függvényében: a 200-UV levelek fotoszintézise a 200-PAR levelekhez képest 60\%-kal volt alacsonyabb, míg az 1000-UV leveleknél az UV nem eredményezett p $<0,05$ szinten szignifikáns csökkenést (8.A ábra). A sztómakonduktancia változása ugyanezt a mintázatot követte, a 200-PAR leveleknél 85\%-os csökkenéssel (az adatok az ábrán nincsenek bemutatva). A maximális fotokémiai hatékonyság $\left(\mathrm{F}_{\mathrm{v}} / \mathrm{F}_{\mathrm{m}}\right)$ a 200-UV növényekben szignifikánsan kisebb volt a 200-PAR levelekhez képest, míg az 1000-UV leveleké az 1000-PAR levelekével megegyező volt (8.B. ábra). Az effektív fotokémiai hatékonyságban ( $\left.\mathrm{Y}_{\mathrm{PSII}-55}\right)$ az UV hatására nem láttunk csökkenést egyik csoportban sem, sőt még egy kisebb növekedést is tapasztalhattunk az 1000-UV növényeknél (az adatok itt nincsenek bemutatva).

A TAC paraméterek közül a TFT értékeiben nem lehetett szignifikáns eltéréseket kimutatni a négy csoport növényei között (8.C ábra). A TEAC értékeinél a magas fényen történő előkezelés 3,5-szörös növekedést eredményezett maradandó hatásként (mivel a növekedés a 6 napos alacsonyabb fényintenzitásra történő visszahelyezés után kimutatható volt, 8.D ábra). A TEAC átlagok különbsége nem volt szignifikáns a 200-UV és 200-PAR levelek között. A FRAP szintekben a magas PAR nem okozott szignifikáns változást, viszont a 200-UV levelek másfélszeres antioxidáns kapacitással rendelkeztek, mint a 200PAR levelek (8.E ábra).

Ebben a kísérletben két ROS-specifikus antioxidáns kapacitás értékét határoztuk meg, a hidroxilgyök és a szuperoxid-gyök kioltási képességet (8.F.-G ábra). Az elöbbi paraméternél nem találtunk szignifikáns különbségeket a négy csoport között. A $\mathrm{O}_{2}{ }^{\circ}$-kioltó kapacitás mértékében a magas fény nem okozott változást. A 200-UV levelek ezen értéke a 200-PAR leveleknek csaknem négyszerese volt, míg a magas fényen előkezelteknél nem tudtuk különbséget kimutatni.

Ebben a kísérletben is mértük a levelek kivonatainak UV-B hullámhosszakon való összesített abszorborbanciáját (8.H ábra). Azt találtuk, hogy míg a magas látható fény nagyobb mértékü, csaknem kétszeres növekedést eredményezett ebben a paraméterben, addig az UV-kezelés hatása nem volt szignifikánsan kimutatható egyik csoportnál sem. A levelek karotenoidtartalmát az UV-kezelés nem befolyásolta. A paraméterek közötti összefüggéseket ebben a kísérletben is a Pearson-féle korrelációs koefficienssel jellemeztuik (csak a szignifikáns változást mutató paraméterek esetében), melynek értékeit az 3. táblázat mutatja és aminek elemzésére később térek vissza. 

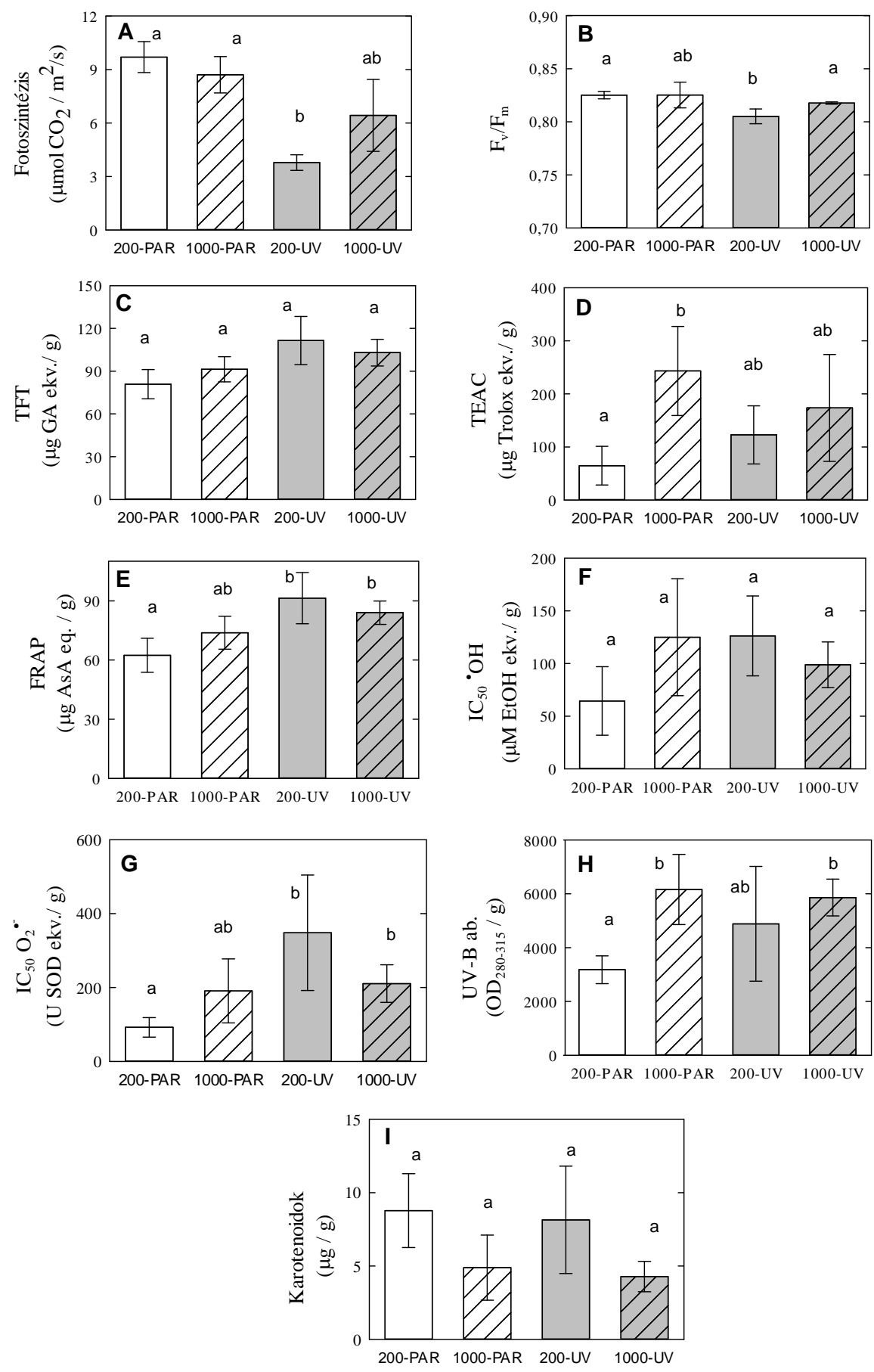

8. ábra: Üvegházi kísérletben különböző kezelésekben részesült dohányok leveleinek fotoszintézise (A), maximális fotokémiai hatékonysága (B), TAC (C-E) és SAC paraméterei (F-G), UV-B abszorbeáló pigmentjei $(\mathrm{H})$, valamint karotenoidtartalma (I). Az oszlopok feletti azonos betük az átlagok egyezését mutatják $\mathrm{p}<0,05$ konfidenciaszinten $(\mathrm{N}=3, \pm \mathrm{SD})$. 
A fenti kísérletek eredményei azt mutatják, hogy az üvegházban nevelt levelek UVakklimációja javítható volt az antioxidáns kapacitás növelésével. A magas fényen előkezelt növények fotoszintézise az alkalmazott UV-kezelés hatására nem csökkent szignifikánsan, míg az elökezelés nélküli növényeké igen. Az elektrontranszport mérések alapján feltételezhetjük, hogy az UV hatására bekövetkező kisebb $\mathrm{CO}_{2}$-felvételben megnyilvánuló fotoszintézis hatékonyságbeli csökkenést az elökezelés nélküli növények esetében nagyobb részben a sztómazáródás, kisebb részben pedig belső tényezők, a PS II hatékonyságcsökkenése okozhatták.

A magas nevelési fényre való áthelyezés antioxidáns rendszert aktíváló hatását például örökzöldek (Grace és Logan 1996) és lóbab csírák (Younis és mtsai. 2010) esetében már kimutatták különböző enzimatikus (APX, SOD) és nemenzimatikus (AsA, GSH) komponensek esetében. A mi kísérletünkben a $1000 \mu \mathrm{mol}$ foton $\mathrm{m}^{-2} \mathrm{~s}^{-1}$ PAR előkezelés jelentősen megnövelte a dohány levelek TEAC értékét és az UV-B abszorbeáló komponenseinek mennyiségét. Fontos megjegyezni, hogy ezek a változások a magas fénnyel történő előkezelés után 6 nappal is megfigyelhetőek voltak, annak ellenére, hogy az 1000-PAR növények az előkezelés utáni 6 napban újra az alacsonyabb fényen voltak tartva. Másik lényegi megfigyelésünk, hogy a magas fény előkezeléssel megnövelt antioxidáns kapacitások megfelelően elhárították a kiegészítő UV-kezelés káros (az elökezelés nélküli csoportban megfigyelhetö) fotoszintézist gátló hatásait, és ezeknek a paramétereknek további emelésében megnyilvánuló akklimatív válaszokat már nem láthattunk. A kísérlet során végig $200 \mu \mathrm{mol}$ foton $\mathrm{m}^{-2} \mathrm{~s}^{-1}$ PAR fényen nött leveleknél viszont a 6 napos UV-besugárzás jelentős növekedést okozott a FRAP értékében, és stimulálta a $\mathrm{O}_{2}{ }^{-}$-kioltó antioxidáns kapacitást is, ami az akklimatív válaszok megindulását jelzi, mégha azok nem is voltak elégségesek a fotoszintézis csökkenésének megakadályozására. Ebből arra következtethetünk, hogy a fentebbi paramétereknek lehet leginkább szerepe az UV elleni védelemben, vagyis a magas fény előkezelés a vizsgált paraméterek közül elsősorban az UV-B abszorbeáló összetevők mennyisége és a TEAC teszttel mérhető antioxidáns kapacitás növelésén keresztül védte meg a leveleket. Érdekes azt is megfigyelni, hogy ebben a kísérletben (bizonyos paraméterek tekintetében) fontosabb szerepük volt az UV-kezelés kezdetén már meglevő magasabb antioxidáns szinteknek, mint ezek UV-indukált növekedésének. A magas fény előkezelés által előidézett, és az ezekben a levelekben a kiegészítő UV hatására már nem növekedő UV abszorbeáló pigmentmennyiséget az alacsony fényen nőtt levelek is tartalmazták az UV kezelés végére. Ez a kísérlet azt mutatta, hogy az UV kezelés során indukálható 
antioxidánsoknak nem volt olyan jelentős védő szerepe, mint a kezelés kezdetén már meglévőknek.

Ez a megállapítás látszólag ellentmond a fiatal és idős szőlőlevelekkel végzett kísérlet eredményeinek, ahol a kezdeti magasabb antioxidáns szintek nem voltak alkalmasak az UV-sugárzáshoz való akklimáció elősegítésében. Azonban, míg abban az esetben egy természetes fejlődési folyamat hatására variáltak az antioxidáns szintek, addig itt a magas fény eredményeképpen specifikusan megnövekedett antioxidáns kapacitásokat figyelhettünk meg, amik jelenléte az UV ellenállóságra kereszttolerancia jellegü hatásukban nyilvánulhatott meg. A fordított irányú akklimációt, vagyis az UV-B előkezelés fotoinhibíciót csökkentő hatását kimutatták már bab és borsó levélkorongokon (Bolink és mtsai. 2001), illetve üvegházban nevelt duglászfenyő magoncokon (Poulson és mtsai. 2002). A fellépő kereszttolerancia jelenségét magyarázhatja, hogy az alacsonyabb UV-B sugárzásra adott válaszok egy része is ROS-mediált útvonalakon keresztuil generálódik (Brosché és Strid 2003; Jenkins 2009), amiben pl. a katalitikusan képződő szuperoxid védelmi útvonalakat közvetlen módon, vagy hidrogén-peroxidon keresztuil indukáló szerepét bizonyították (Mackerness és mtsai. 2001).

A korrelációk elemzése (3. táblázat) is segít abban, hogy ennek a feltételezett kereszttoleranciának a kialakításában szereplő faktorokat azonosíthassuk. A $\mathrm{O}_{2}{ }^{\bullet-}$-kioltás szoros negatív korrelációja a $\mathrm{CO}_{2}$-asszimilációval $\left(\mathrm{R}_{\mathrm{P}}=-0,96\right)$ és az $\mathrm{F}_{\mathrm{v}} / \mathrm{F}_{\mathrm{m}}$ paraméterrel $\left(R_{P}=-0,92\right)$ ennek a ROS-nak a kiemelt szerepére utal a vizsgált körülmények között. A FRAP paraméter ennél a kísérletnél jó összefüggést mutatott a $\mathrm{O}_{2}{ }^{-}$-kioltással $\left(\mathrm{R}_{\mathrm{P}}=0,95\right)$, ami utalhat arra, hogy a teljes antioxidáns kapacitás jelentős része itt ennek a ROS-nak a semlegesítésére fordítódott. A TEAC paraméter, aminek értéke a legnagyobb mértékü (3,5szörös) emelkedést mutatta a magas fény előkezelés hatására, az UV-B abszorbeáló vegyületek felhalmozódásával szorosan összefügg $\left(R_{P}=0,94\right)$, ami - a magas fény előkezelés indukáló hatása mellett - megerősíti, hogy ezen vegyületek elsődleges szerepe az antioxidáns hatásukban lehet. Az UV-B hullámhosszon történő abszorpcióért felelös növényi komponensek nagyrészt a fenolos vegyületek közül kerülnek ki (Levizou és Manetas 2002). A levelek fenolos vegyületei között a legjobban tanulmányozottak a magas PAR illetve UV-besugárzásra egyaránt indukálódó flavonoidok (Winkel-Shirley 2002; Zhang és Björn 2009). A flavonoid deficiens mutánsok fokozott UV-B érzékenysége (Li és mtsai 1993; Reuber és mtsai. 1996) is utalhat e vegyületcsoport meghatározó szerepére az UV toleranciában, amit elsősorban az alacsony hullámhosszú sugárzást kiszürő szerepüknek tulajdonítanak (Caldwell és mtsai. 1983). Viszont a flavonoidok elsődleges 
szerepének természete a fényakklimációban vitatott, mert UV-szürő jelentőségük mellett antioxidáns hatásaikra is vannak bizonyítékok (1. Agati és Tattini 2010 összefoglalója). Ezért a következőkben ismertetendő kísérletünk a flavonoid vegyületek levelek fényhez (magas fényintenzitás és UV természetes arányokban) történő akklimációjában játszott szerepére irányultak. Ehhez az előzőekben bemutatott laboratóriumi kísérletek helyett természetes fényviszonyok között vizsgálatuk napon illetve árnyékban nőtt levelek ezen jellemzőit.

3. táblázat: Összefüggések üvegházi kísérletben különböző kezelésekben részesült dohányok leveleinek maximális fotokémiai hatékonysága, fotoszintézise, UV-B abszorbeáló pigmentjei, valamint TAC és SAC értékei között. Az összefüggések erősségét a Pearson-féle korrelációs együtthatóval $\left(\mathrm{R}_{\mathrm{P}}\right)$ jellemeztük. Ahol $\left|R_{P}\right|>0,8$, a táblázatban vastag betűs kiemelés jelzi.

\begin{tabular}{|c|c|c|c|c|c|c|}
\hline $\mathbf{R}_{\mathbf{P}}$ & $\mathrm{F}_{\mathrm{v}} / \mathrm{F}_{\mathrm{m}}$ & Fot & TEAC & FRAP & $\mathrm{IC}_{50} \mathrm{O}_{2}^{*-}$ & UV-B ab \\
\hline $\mathrm{F}_{\mathrm{v}} / \mathrm{F}_{\mathrm{m}}$ & 1 & 0.98 & 0.19 & -0.88 & -0.92 & -0.09 \\
\hline Fot & & 1 & 0.00 & -0.96 & -0.96 & -0.29 \\
\hline TEAC & & & 1 & 0.25 & 0.19 & 0.94 \\
\hline FRAP & & & & 1 & 0.95 & 0.54 \\
\hline $\mathrm{IC}_{50} \mathrm{O}_{2}^{*-}$ & & & & & 1 & 0.42 \\
\hline UV-B ab & & & & & & 1 \\
\hline
\end{tabular}

\subsection{Különböző napfényviszonyokhoz alkalmazkodott levelek fényakklimációja és a flavonoidok lehetséges szerepe a folyamatban}

Az előzőekben ismertetett laboratóriumi kísérletek már jelezték a rövid idejü (néhány napos) magas fényintenzitáshoz történő akklimáció UV-sugárzás okozta oxidatív stressz elleni védelemre is kiterjedő szerepét, így a továbbiakban a hosszabb távon, a levelek teljes fejlődési ideje alatt kialakuló antioxidáns védelem szerepét is megvizsgáltuk. Az üvegházi körülmények között alkalmazott nagy intenzitású (a nevelöfény négyszeresét képviselő) PAR hatása már jelezte, hogy az irodalomban általában UV-abszorbeáló pigmentek névvel jelzett vegyületek mennyisége a levelekben a magas PAR alkalmazkodással megnő, így feltételeztük, hogy a látható fény stresszhatásai elleni védelmet is szolgálhatja. Az Irodalmi áttekintésben (2.4.2.) ismertetett fotoinhibíció védelem két legfontosabb módja a megelőzés, vagyis a fotokémiailag fel nem használt energia szabályozott elvezetése, illetve a ROS-kioltáson alapuló védelem (Jung és Niyogi 2006). A PS II fotoinhibíciója során keletkező egyik legfontosabb ROS a ${ }^{1} \mathrm{O}_{2}$, melynek 
keletkezését már kísérletileg is bizonyították, az izolált reakciócentrumtól a levelekig terjedő szinteken végzett vizsgálatokban (összefoglaló munka Fischer és mtsai. 2013).

Az üvegházi kísérletek hátránya, hogy nem, vagy csak költséges technikai apparátussal lehetséges a természetes napfény PAR intenzitását és spektrumát is szimuláló, kontrollálható megvilágítási viszonyokat teremteni. Egy előkísérletben, ami átmenetet jelentett az üvegházi és szabadföldi munka között, megvizsgáltuk a szabadtérihez képest alacsony fényintenzitáson nőtt (AFI, $200 \mu \mathrm{mol}$ foton $\mathrm{m}^{-2} \mathrm{~s}^{-1} \mathrm{PAR}$ ), üvegházban nevelkedett és az ugyanilyen körülmények közt nőtt, de 7 napra szabadtéri fényviszonyokra (UV-szürö fólia alá) kihelyezett (magas fényintenzitáshoz akklimálódott, MFI, max. $1500 \mu$ mol foton $\mathrm{m}^{-2} \mathrm{~s}^{-1} \mathrm{PAR}$ ) dohány növények leveleit. A természetes napfényhez a 7 nap alatt a növények alkalmazkodtak, nem csökkent le fotokémiai hatékonyságuk. A fenti előkészítő kezelés után az egy órás fotoinhibíciót indukáló erős mesterséges megvilágítás (2000 $\mu$ mol foton $\left.\mathrm{m}^{-2} \mathrm{~s}^{-1} \mathrm{PAR}\right)$ hatását vizsgáltuk a kétféle növénycsoportban. A kísérletben egy ${ }^{1} \mathrm{O}_{2}$ specifikus fluoreszcens jelző (DanePy, Kálai és mtsai. 1998) segítségével kimutattuk, hogy a ${ }^{1} \mathrm{O}_{2}$ csak az AFI levelekben volt megfigyelhető, míg a MFI levelekben nem, vagy csak a mérőmódszer érzékenységét el nem érő mennyiségben keletkezett (Hideg és Majer 2010). A ${ }^{1} \mathrm{O}_{2}$ keletkezést csökkentő preventív védelem szerepét klorofill fluoreszcenciás mérésekkel, Klughammer és Schreiber (2008) modellje alapján vizsgáltuk. A modellben az abszorbeált fény megoszlásának vizsgálata tájékoztatást ad az energia fotokémiai hasznosításának ( $\left.\mathrm{Y}_{\mathrm{PSII}}\right)$, illetve a szabályozott ( $\left.\mathrm{Y}_{\mathrm{NPQ}}\right)$ és szabályozatlan ( $\left.\mathrm{Y}_{\mathrm{NO}}\right)$ energialeadási folyamatoknak az arányáról (bővebb leírás az Anyagok és módszerek fejezetben található). Ez alapján azokon a magas fényintenzitásokon, ahol a fotokémiai folyamatok fotoinhibíció fellépése miatt már nem működőképesek, a szabályozott illetve szabályozatlan formákban való energialeadás, illetve -vesztés aránya mutatja a levelek fizikai fényvédelmének kapacitását a többlet fényenergia elleni védelemben. A kísérletben azt tapasztaltuk, hogy a magas fényintenzitáson történő akklimáció hatásaként az abszorbeált fényenergia csak kisebb része veszett el szabályozatlan folyamatokban ( $\left.\mathrm{Y}_{\mathrm{NO}}\right)$, mint az AFI leveleknél. A laboratóriumi fotoinhibíció után mért fotokémiai hatékonyság (Y YSII) mind az AFI, mind a MFI leveleknél jóval alacsonyabb volt, de az AFI növények levelei már $200 \mu \mathrm{mol}$ foton $\mathrm{m}^{-2} \mathrm{~s}^{-1}$ PAR fényintenzitáson sem tudták a fényenergiát fotokémiailag hasznosítani, míg az MFI levelek képesek voltak magasabb fényen is fenntartani az elektrontranszportot, illetve az energiaveszteségüknek nagyobb részét tették ki a szabályozott nem fotokémiai disszipációs folyamatok ( $\left.\mathrm{Y}_{\mathrm{NPQ}}\right)$ (9. ábra). A fenti mérések ugyan bizonyították a preventív folyamatok szerepét a fotoinhibíció elleni 
védelemben, de nem ez volt a MFI levelek egyetlen védelmi útja. Az antioxidáns út hozzájárulását is kimutattuk: a MFI levelek vizes kivonatának ${ }^{1} \mathrm{O}_{2}$ antioxidáns kapacitása egy nagyságrenddel nagyobb volt, mint az AFI leveleké (Hideg és Majer 2010).
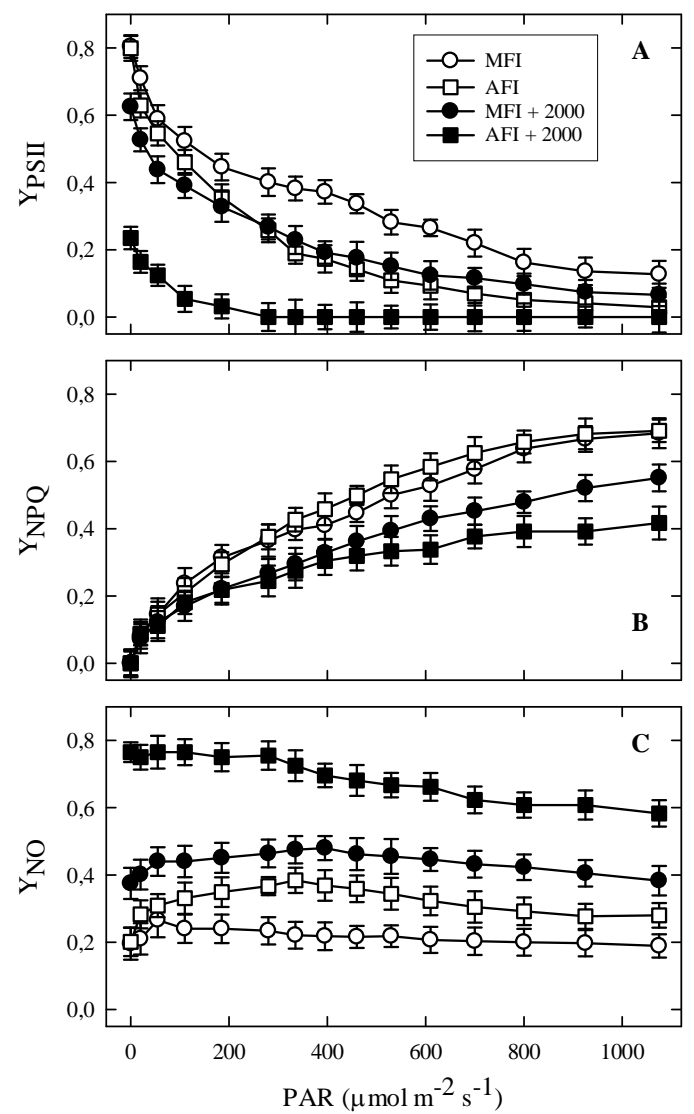

9. ábra: Üvegházban alacsony fényintenzitáson nőtt (AFI) és 7 napra szabadföldre, magas fényintenzitásra (MFI) helyezett dohányok leveleinek klorofill fluoreszcencia paraméterei kezelés nélkül és egy órás $2000 \mu \mathrm{mol}$ foton $\mathrm{m}^{-2} \mathrm{~s}^{-1}$ PAR fénnyel történő megvilágítás után (MFI +2000 , illetve AFI +2000$)$ $(\mathrm{N}=3, \pm \mathrm{SD})$. A paramétereket Klughammer és Schreiber (2008) leírása alapján számoltuk, ahol minden fényintenzitáson $\mathrm{Y}_{\mathrm{PSII}}+\mathrm{Y}_{\mathrm{NPQ}}+\mathrm{Y}_{\mathrm{NO}}=1$.

Ezek az eredmények mindkét védelmi útvonal, a megelőző, és a keletkező ${ }^{1} \mathrm{O}_{2}$ semlegesítésén alapuló utak szerepét is alátámasztják, viszont csak egy rövid, egyhetes napfényen történő akklimációt jellemeznek. Ezért vizsgálatainkat e kérdésben tovább folytattuk és a következőkben fényen és árnyékban nőtt hársfalevelek akklimációját vizsgáltuk, amelyek kifejlődésük teljes időtartamában mind látható-, mind UV-sugárzás tekintetében eltérö fényviszonyokhoz alkalmazkodtak

A kísérlethez egy nagylevelü hársfáról Szegeden, júliusban gyüjtöttünk be napfényen (fénylevél, FL), illetve árnyékban nőtt leveleket (árnyéklevél, ÁL), majd mértük 
azok fotokémiai jellemzőit, a levélkivonatok ${ }^{1} \mathrm{O}_{2}$-kioltó képességét, flavonoidtartalmát és abszorpciós spektrumát. A preventív védelem szerepét itt is a Klughammer és Schreiber (2008) modell alapján becsültük fel. Vizsgálataink szerint a magas fényintenzitáshoz alkalmozkodott hárslevelek az abszorbeált energia nagyobb részét tudták fotokémiai úton hasznosítani ( $\left.\mathrm{Y}_{\mathrm{PSII}}\right)$, és különbségeket figyelhettünk meg a többletenergia megoszlását illetően is (10. ábra). Míg alacsony PAR-on a fény- és árnyéklevelek az abszorbeált energiának nagyjából ugyanakkora részét tudták szabályozott úton leadni, addig azokon a fényintenzitásokon, ahol a fotokémiai hatékonyság már teljesen lecsökkent a PI hatására (FL esetében $880 \mu \mathrm{mol}$ foton $\mathrm{m}^{-2} \mathrm{~s}^{-1} \mathrm{PAR}$, AL esetében pedig $620 \mu \mathrm{mol}$ foton $\mathrm{m}^{-2} \mathrm{~s}^{-1}$ PAR felett), a fénylevelek még mindig képesek voltak az elveszett energiát szabályozott disszipációs folyamatokba $\left(\mathrm{Y}_{\mathrm{NPQ}}\right)$ átcsoportosítani, míg az árnyékleveleknél ez az energia nagyobbrészt passzív veszteségként jelent meg $\left(\mathrm{Y}_{\mathrm{NO}}\right)$. Hallik és mtsai (2012) ugyanezt a tendenciát figyelték meg különböző fényintenzitásokon nőtt kislevelü hárs (Tilia cordata Mill.) leveleknél, levonva a következtetést, hogy a napon nőtt hárslevelek a magas fény indukálta károsodást a magasabb szinten tartott fotokémiai kioltás által jobban elkerülik, mint az árnyékban nevelkedettek. Klorofill fluoreszcenciás jellemzőik alapján tehát a fényen nőtt hárs levelek megfelelő védelemmel vannak ellátva az oxidatív károsodás elkerülésére.

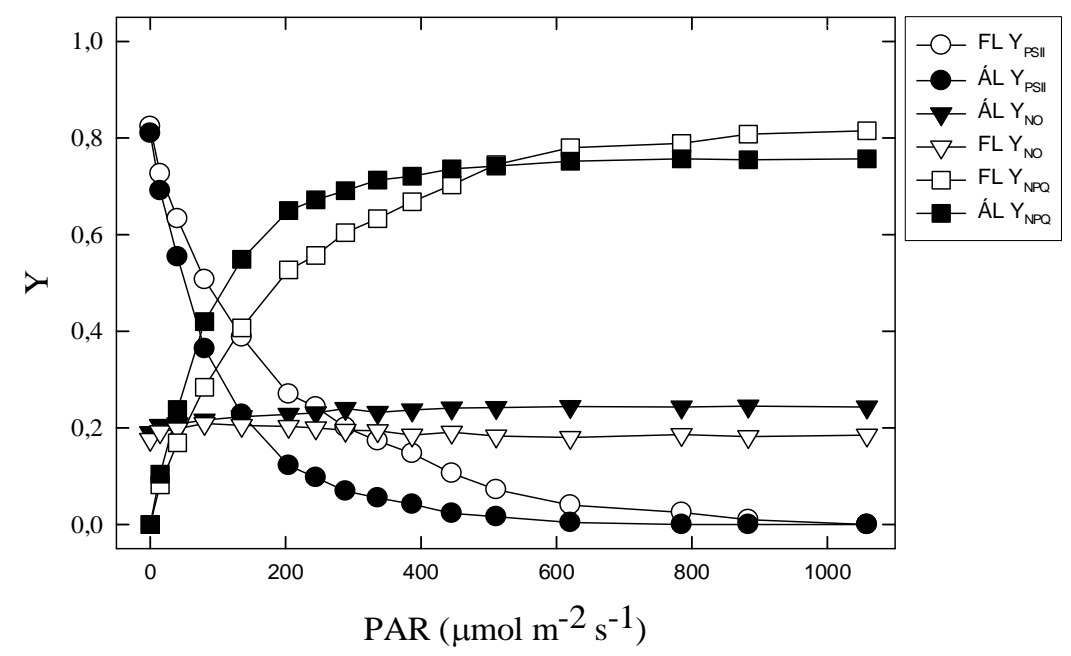

10. ábra: Természetes napfényen fejlődött hársfa fénylevelek (FL) és árnyéklevelek (ÁL) klorofill fluoreszcencia paraméterei. A paramétereket Klughammer és Schreiber (2008) leírása alapján számoltuk, ahol minden fényintenzitáson $\mathrm{Y}_{\mathrm{PSII}}+\mathrm{Y}_{\mathrm{NPQ}}+\mathrm{Y}_{\mathrm{NO}}=1$. (A szórások a könnyebb átláthatóság kedvéért nincsenek feltüntetve, értékük kisebb, mint 5\%). 
A specifikus ROS antioxidáns kapacitás vizsgálatok azonban azt mutatták, hogy a levelek kivonatainak ${ }^{1} \mathrm{O}_{2}$-kioltása között mégis nagy különbségek mutatkoztak: a fénylevelek 5,4-szeres antioxidáns kapacitással rendelkeztek az árnyéklevelekhez képest. Mindez arra utal, hogy a napon nőtt levelek az energiadisszipáció mellett más módon is védekeznek a magas fény ellen. $\mathrm{A}^{1} \mathrm{O}_{2}$ semlegesítésében számos, az Irodalmi áttekintésben ismertett vegyület részt vehet. Mi ezek közül a fenolos vegyületekre fordítottuk figyelmünket, mivel az előző kísérletek kimutatták az antioxidáns hatású UV-B abszorbeáló anyagok kiemelt jelentőségét a fényhez (magas PAR és UV) történő akklimációban. A fenolos vegyületek nagyon széles csoportjából a jól jellemzett és a hársfajokban nagy koncentrációban jelenlévő (kb. 1\%, Toker és mtsai. 2001) flavonoidokat választottuk ki további elemzésre. A napon és árnyékban nevelkedett levelek flavonoidtartalmát HPLC-DAD-ESI-MS/MS módszerrel elemeztük. Mivel több ezer flavonoid vegyületet ismerünk (Jäger és Saaby 2011), s maga a vizsgált faj, a nagylevelü hárs is számos különböző ilyen vegyületet tartalmaz, melyek egy része még beazonosítatlan is (Toker és mtsai. 2009), mi a flavonoidok aglükonjainak (flavonolok) meghatározását és kvantifikálását tüztük ki célul.

Három különböző flavonolt azonosítottunk a mintákban: kempferolt, kvercetint és miricetint (a vegyületek szerkezetét a 11. ábra mutatja). Ahogy a 12. ábrán látható, mind mennyiségét, mind összetételét tekintve jelentős különbségeket láthattunk a két típusú levél flavonoidprofiljában. Az árnyékevelek szárazsúlyra vonatkoztatva $5,1 \mathrm{mg} \mathrm{g}^{-1}$, míg a fénylevelek 21,5 $\mathrm{mg} \mathrm{g}^{-1}$, vagyis több, mint négyszeres mennyiségü flavonoid vegyületet tartalmaztak. Az árnyéklevelekben legnagyobb arányban, 86\%-ban a kempferol volt jelen (4,3 $\left.\mathrm{mg} \mathrm{g}^{-1}\right)$, míg a kvercetin aránya $14 \%$-ot tett ki $\left(0,7 \mathrm{mg} \mathrm{g}^{-1}\right)$, a miricetin pedig csak nyomokban volt detektálható $\left(0,1 \mathrm{mg} \mathrm{g}^{-1}\right)$. A napfényen nőtt levelekben ezzel szemben a kvercetin aránya $71 \%$ volt $\left(15,2 \mathrm{mg} \mathrm{g}^{-1}\right)$, míg a kempferol $22 \%$-ot tett $\mathrm{ki}\left(4,7 \mathrm{mg} \mathrm{g}^{-1}\right)$, illetve a miricetin képezte a levél összes flavonoidtartalmának 7\%-át (1,6 mg g $\left.\mathrm{g}^{-1}\right) . \mathrm{Az}$ Európai Gyógyszerügynökség (EMA 2011) a három hársfajból készült virágdrogban ugyanennek a három flavonolnak a jelenlétét írta le, azonban a levelek, és föképp az adott faj, a Tilia platyphyllos levelének flavonol-összetételéről nem született sok tanulmány eddig. Toker és mtsai (2011) szintén HPLC segítségével 9 különböző flavonoidot találtak a nagylevelü hárs levelében (köztük 3 beazonosítatlan), amelyek kvercetin- és kempferolglükozidok voltak. A kvercetin vegyületek a teljes flavonoidtartalomnak kb. 62\%-át tették ki, ami közel áll az általunk a fénylevelekben megfigyelt arányhoz (71\%). Méréseink alapján a kvercetin mennyiségének különbsége volt a legkiugróbb a két különböző 
levéltípus között: a fénylevelek több, mint 20-szoros koncentrációban tartalmazták ezt a flavonolt a a levelek szárazanyag tartalmára vonatkoztatva.

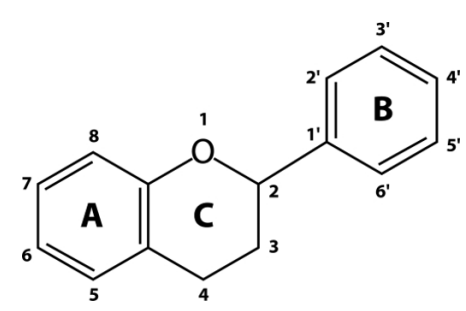

Flavonoidok általános szerkezete
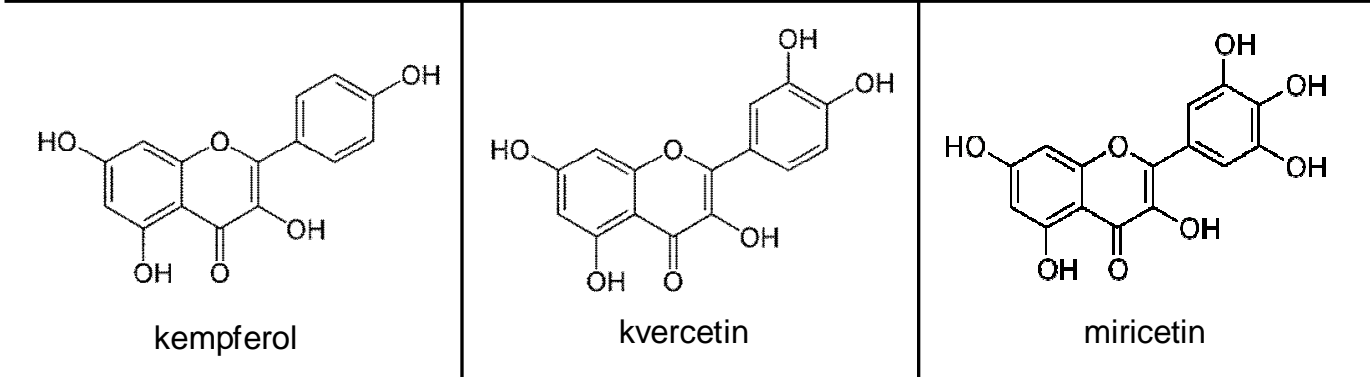

11. ábra: Flavonoidok általános szerkezete, illetve a kempferol, a kvercetin és a miricetin szerkezete. A három flavonol vegyület csak a hidroxilcsoportok számában és elhelyezkedésében különbözik egymástól.

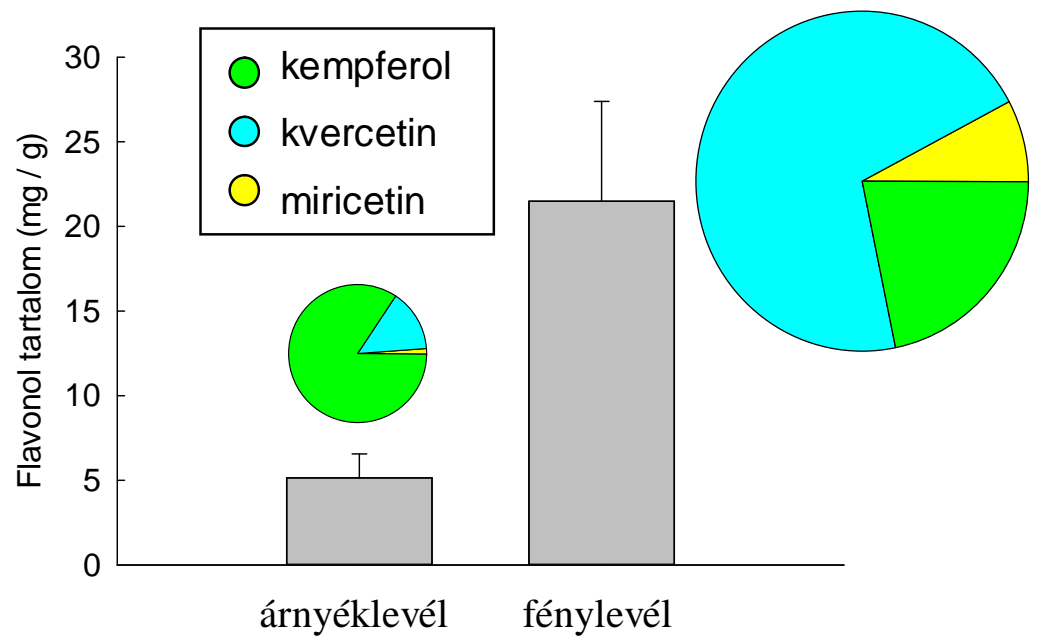

12. ábra: Természetes napfényen fejlödött hársfa árnyéklevelek és fénylevelek flavonoltartalma és a flavonolvegyületek aránya $(\mathrm{N}=5, \pm \mathrm{SD})$. 
Az UV-sugárzás, illetve napfény hatására bekövetköző kvercetin:kempferol arány növekedése más fajoknál is gyakran megfigyelt jelenség (Ryan és mtsai. 1998, 2001; Hofmann és mtsai. 2000; Jaakola és mtsai. 2004; Reifenrath és Müller 2007). Bidel és mtsai. (2007) tanulmánya szerint fafajok napleveleiben a kvercetin-glükozidok felhalmozódása általános válasznak tekinthető. Azzal a céllal, hogy értékelhessük ennek az arányeltolódásnak a jelentőségét a levelek fotoinhibíció elleni védelmében, a flavonolok ${ }^{1} \mathrm{O}_{2}$-kioltó képességét és UV-fényszürő szerepét vizsgáltuk a továbbiakban.

A vegytiszta, kereskedelmi forgalomból származó flavonolvegyületek ${ }^{1} \mathrm{O}_{2}$ antioxidáns kapacitását a levélkivonatokéval egyező módon teszteltük. A három tanulmányozott flavonol közül a miricetin volt a legerősebb ${ }^{1} \mathrm{O}_{2}$ antioxidáns $(4,2 \mu$ mol Trolox ekv. $\left.\mu \mathrm{mol}^{-1}\right)$, ezt követte a kvercetin $\left(3,1 \mu\right.$ mol Trolox ekv. $\left.\mu \mathrm{mol}^{-1}\right)$, majd a kempferol $\left(2,7 \mu \mathrm{mol}\right.$ Trolox ekv. $\left.\mu \mathrm{mol}^{-1}\right)$. Két hárslevél mintáinkban is jelen lévő glükozidos forma esetében is mértük ezt a paramétert: a kvercetin-3-glükozid a kvercetinnél jóval gyengébb $\left(2,1 \mu \mathrm{mol}\right.$ Trolox ekv. $\left.\mu \mathrm{mol}^{-1}\right)$, míg a kempferol-3-glükozid alig mérhető aktivitású $\left(0,2 \mu \mathrm{mol}\right.$ Trolox ekv. $\left.\mu \mathrm{mol}^{-1}\right)$ volt.

A flavonoidok UV elleni védelemben játszott fényszürő szerepének tanulmányozására a hársnál megmértük a detektált flavonolok abszorpcióját is vizesmetanolos kivonatukban. Ahogy a 13. A ábra mutatja, a három vizsgált flavonol fényelnyelési maximuma a spektrum UV-A hullámhosszain van (350-400 nm között), kissé eltérő csúcsokkal. A glükozidok abszorpciós csúcsa (itt a kvercetin-3-glükozid és a kempferol-3-glükozid abszorpciója látható) a vonatkozó aglükonos formákhoz képest kissé (kb. 20 nm-rel) a rövidebb hollámhosszok irányába tolódik el (13. B ábra). Vagyis a nagyobb energiájú UV-B hullámhosszokon (280-315 nm) a vizsgált flavonoidok fényelnyelése kevésbé jelentős, ráadásul a két vizsgált glükozid példája azt mutatja, hogy ebben a tartományban nincs abszorpciójuk között jelentős különbség, ami indokolhatná a kvercetinek fokozott szintézisét.

A fény- és árnyéklevelek kivonatainak is nagy mértékben különbözött az abszorpciós spektruma (13. C ábra). Az UV-B abszorbancia ( $\left.\mathrm{OD}_{280-315}\right)$ mértéke a fényleveleknél 2-szerese volt az árnyékleveleknél mértnek. Habár a mérések a teljes levelek kivonataiból történtek, így nem különíthetjük el az epidermiszben lokalizált fényvédő pigmenteket, mégis azt láthattuk, hogy az UV-B elleni fizikai védelemnek a fényleveleknél nem a vizsgált flavonolok a fő alkotói. Más fenolos vegyületek, például a hidroxi-fahéjsav származékai abszorpciós spektrumuk alapján alkalmasabbak lehetnek erre 
a szerepre (Harborne és Williams 2000). Arabidopsisnál a kvercetintermelés fényfüggésének vizsgálata azt mutatta, hogy a vegyület akkumulációja valóban fokozódik az UV-dózis növekedésével, és természetes UV:PAR arányok mellett hullámhossz-függést is mutat (vagyis az UV-B sugarak jobban indukálják, mint az UV-A), viszont a a látható fény intenzitása szinergetikus hatással bír az indukcióban (Götz és mtsai. 2010). Ráadásul, kvercetinhiányos Arabidopsis mutánsoknál nagyobb UV-B érzékenységet tapasztaltak, mint a vad típusnál, ami a kempferol kisebb hatékonyságát mutatta a védelemben (Ryan és mtsai. 2001). Mindez megerősíti azt az elképzelést, hogy a flavonoid vegyületeknek más, antioxidáns funkciói is szerepet játszhatnak az UV elleni védelemben.

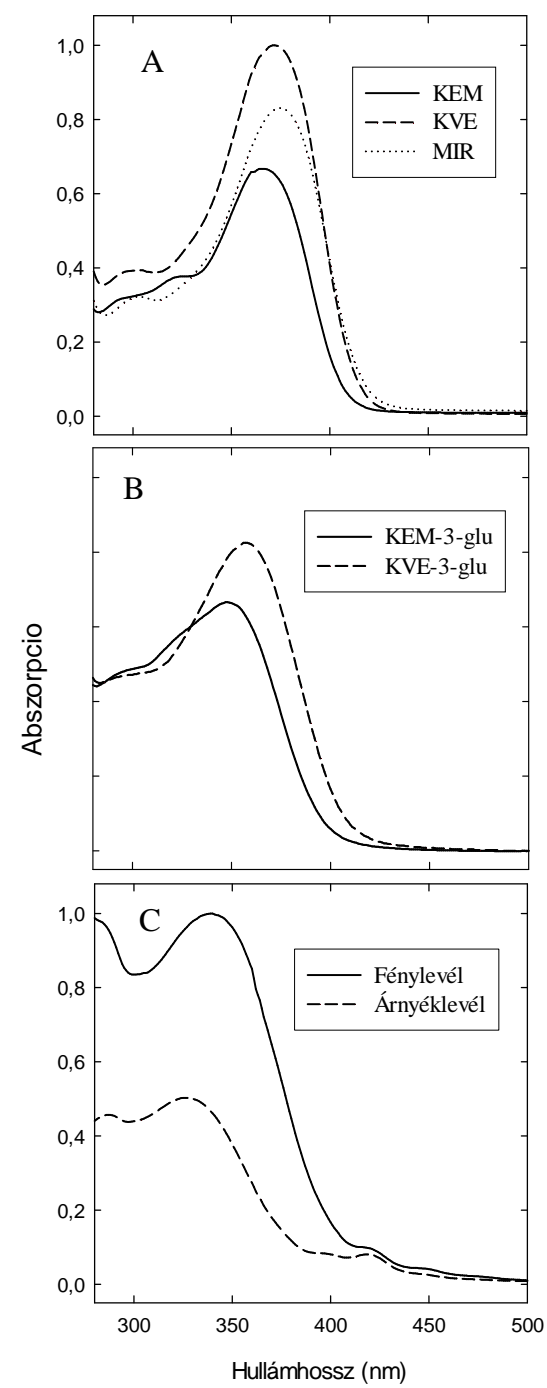

13. ábra: (A) Flavonolok (kempferol, kvercetin, miricetin), (B) flavonol-glükozidok (kempferol-3glükozid és kvercetin-3-glükozid) és (C) természetes napfényen fejlödött hársfa fény- és árnyéklevelek abszorpciós spektruma 280 és 500 nm között. 
A flavonoidok antioxidáns szerepét már régóta ismerik és bizonyították in vitro tesztekben, szuperoxidgyök (Hu és mtsai. 1995), hidroxilgyök (Husain és mtsai. 1987), ${ }^{1} \mathrm{O}_{2}$ (Tournaire és mtsai. 1993) és más szabadgyökök semlegesítésében is (Rice-Evans és mtsai. 1995, 1996; Khanduja és Bhardwaj 2003). A flavonoidok szerkezetének és antioxidáns kapacitásának viszonyáról számos tanulmány született. A flavonoidok általános szerkezetét és a három vizsgált flavonol struktúráját a 11. ábra mutatja. Látható, hogy ezek csupán a Bgyürűn található hidroxilcsoportok $(-\mathrm{OH})$ jelenlétében különböznek egymástól: a kempferol esetében egy (4'-OH), a kvercetinnél kettő (3'- és 4'-OH), a miricetinnél pedig három (3'- és 4'-, 5'-OH) található. A vizsgálatok alapján a B-gyürün található hidroxilcsoportok száma befolyásolja a szuperoxidgyökkel, vagy az ABTS-gyökkel szembeni reaktivitást (Hu és mtsai. 1995; Heim és mtsai. 2002). A ${ }^{1} \mathrm{O}_{2}$ elleni in vitro kioltásnál ugyanezt, illetve a C-gyürü szerepét emelte ki Tournaire és mtsai. (1993) tanulmánya. Rice-Evans és mtsai. (1996) egy kvercetin > miricetin > kempferol aktivitásbeli sorrendet javasolt a TEAC mérések alapján $(4,7 \mathrm{mM}>3,1 \mathrm{mM}>1,34 \mathrm{mM}$, ahol TEAC $=1$, amikor az oldat aktivitása $1 \mathrm{mM}$ Trolox ekvivalensnek felel meg ). Mások a DPPH próbát használva a miricetinre és kvercetinre egyezö, míg a kempferolra jóval alacsonyabb értéket kaptak (Khanduja és Bhardwaj 2003). A flavonoid glükozidok antioxidáns kapacitása gyengébb, mint az aglükonos formáiké (Ratty és Das 1988; Montoro és mtsai. 2005), ahogy ezt a mi méréseink is alátámasztották a ${ }^{1} \mathrm{O}_{2}$ specifikus antioxidáns kapacitás tekintetében.

Habár a különböző mérési módszerek más és más eredményeket adnak az egyes flavonoidok antioxidáns kapacitására az abszorpciós spectrum adatokkal együttvéve mindenképp megerősítik, hogy a flavonoidtartalom növekedésével nő a levél antioxidáns kapacitása is. A mi méréseink alapján a kvercetin és miricetin glükozidok koncentrációjának emelkedése a kempferol glükozidokkal szemben nagyobb ${ }^{1} \mathrm{O}_{2}$ antioxidáns kapacitást biztosít a fényleveleknél, ami hozzájárul a napon nőtt hárslevelek magas fényintenzitáshoz és UV-B sugárzáshoz történő akklimációjához. 


\section{KÖVETKEZTETÉSEK}

Munkánk során különböző, üvegházban mesterségesen szabályozott, vagy szabadföldi fényviszonyok közt nevelt növényeket vizsgáltunk, arra keresve a választ, hogyan befolyásoják az antioxidánsaik a változó fényviszonyokhoz történő alkalmazkodást. Az alkalmazkodás mértékét fotoszintézis mérésekkel jellemeztük az antioxidánsokat pedig különböző teljes- illetve egyes ROS-okkal szembeni specifikus semlegesítő kapacitás (TAC illetve SAC) próbákkal vizsgáltuk.

1. Megállapítottuk, hogy az általános, teljes antioxidáns kapacitásokat mérő paraméterek alapvetően érzékenyek és jól követik a természetes folyamatokból, mint a szeneszcenciából vagy a levelek különböző korából eredő, illetve az akklimációs hatásokra válaszul kialakuló fiziológiai változásokat (Majer és mtsai. 2010). Bár a szakirodalom a TEAC, a FRAP és a TFT próbát ugyanazon jellemzö, vagyis a teljes antioxidáns kapacitás (elektrontranszfer reakció alapján müködő) paraméterének tekinti, vizsgálataink azt mutatták, hogy az adott hatástól függően (szeneszcencia, oxidatív stressz, fényakklimáció) ezek nem egységesen írják le az antioxidáns változásokat. Az antioxidáns kapacitások értelmezésekor is óvatosan kell eljárni: figyelembe véve a finomszabályott redox egyensúlyt, az alacsony antioxidáns kapacitás értékek egyaránt jelezhetnek oxidatív stresszhelyzetet (elégtelen antioxidáns védelem), illetve akklimáció során beállt új egyensúlyi állapotot. Ezért ezeket a paramétereket mindig fiziológiai mérésekkel kiegészítve kell alkalmazni, hogy képet kaphassunk a növény állapotáról. Ugyan többször történt próbálkozás egy általánosan használható, standard módszer kiválasztására minták antioxidáns jellemzésére, a mi eredményeink inkább azt támasztják alá, hogy ne egy ilyen egydimenziós módszerrel, hanem inkább több TAC paraméterrel írjuk le mintáinkat, ezeket specifikus ROS antioxidáns próbákkal kiegészítve.

2. Különböző korú szőlőlevelek vizsgálatával megállapítottuk, hogy a fiatal levelek jobb UV-akklimációjának alapja antioxidánsaik indukciója, míg az idős leveleket e paraméterek eleve magasabb értékei nem védték meg az UV károsító hatásától (Majer és Hideg 2012a). A TAC mellett a specifikus ROS-kioltásokat mérö próbák válaszait is különbözőnek találtuk, pl. a szeneszcencia folyamatát egyáltalán nem jellemezte határozott irányú változásuk, viszont segítségükkel kimutatható volt $\mathrm{O}_{2}{ }^{*}$ és 
${ }^{\circ} \mathrm{OH}$, illetve ${ }^{1} \mathrm{O}_{2}$ antioxidánsok szerepe az UV-akklimációban. Ezen kísérlet tanulságai alapján azt is megvizsgáltuk, hogy a különböző korú levelek természetes módon eltérö antioxidáns kapacitásai helyett ugyanolyan korú levelek előkezeléssel mesterségesen befolyásolt különbségei is kiválthatnak-e hasonló UV védő hatást.

3. Megállapítottuk, hogy dohány levelekben a néhány napos magas fény előkezeléssel indukálható magasabb antioxidáns kapacitás elősegítette az ezután alkalmazott kiegészítő UV-kezeléshez történő akklimációt (Majer és Hideg 2012b). Ez az eredmény jelezte a lehetséges kereszt-tolerancia utak szerepét, ami feltételezi hogy az UV-B fényhez és a nagy intenzitású PAR-hoz történő alkalmazkodásban közös, antioxidáns védelmet indukáló utak játszhatnak szerepet. Ezt a feltételezést erősítette meg az a megfigyelésünk, hogy az UV-B abszorbeáló komponensek magas fény által is indukálhatóaknak bizonyultak. Ezért figyelmünket a flavonoidok, mint e vegyületek legjelentősebb csoportjának akklimációt elősegítő szerepére fordítottuk.

4. Megfigyeltük, hogy a napfényhez adaptálódott levelek esetében a preventív (szabályozott energia disszipáló) védelmi utak müködése mellett is jelentős a ${ }^{1} \mathbf{O}_{2}$ specifikus antioxidánsok mennyiségének növekedése (Hideg és Majer 2010). Mivel a magas fényhez történő rövidtávú, néhány napos alkalmazkodásban is központinak találtuk a ${ }^{1} \mathrm{O}_{2}$-kioltás szerepét, ezért a természetes napfényben fejlődő hárs fény- és árnyékleveleinek flavonoidtartalmát ennek a paraméternek a vizsgálatával összefüggésben elemeztük.

5. Megállapítottuk, hogy a fény- és árnyéklevelek flavonoidtartalmának nagy mértékü különbségét elsősorban a kvercetin és kempferol arány fénylevelekbeni növekedése, illetve a miricetin fénylevelekbeni jelenléte jellemezte. Ezen flavonoidok antioxidáns kapacitásának és abszorbciós spektrumaik in vitro elemzése azt mutatta, hogy szerepük a a fényakklimáció során inkább fotoinhibíció ellen védő antioxidáns, mint UV-szürő (Majer és mtsai. kézirat). Mindez azt mutatja, hogy az együttesen UV-B abszorbeáló pigmentek néven jelzett vegyületcsoport szerepe az alkalmazkodási folyamatokban az eddigiekben feltételezettnél sokrétűbb és felveti annak lehetőségét, hogy a napfényhez történő akklimációban UV-indukálható reakcióutak is segíthetik a látható (PAR) komponens által okozott oxidatív stressz kivédését. 


\section{IRODALOMJEGYZÉK}

Adir N, Zer H, Shochat S, Ohad I (2003) Photoinhibition - a historical perspective. Photosynth Res. 76(1-3):343-370.

Agati G, Matteini P, Goti A, Tattini M (2007) Chloroplast-located flavonoids can scavenge singlet oxygen. New Phytol. 174(1):77-89.

Agati G, Tattini M (2010) Multiple functional roles of flavonoids in photoprotection. New Phytologist 186:786-793.

Agrawal SB, Singh S, Agrawal M (2009) Ultraviolet-B induced changes in gene expression and antioxidants in plants. Adv. Bot. Res. 52:47-86.

Allen RD (1995) Dissection of oxidative stress tolerance using transgenic plants. Plant Physiol. 107:1049-1054.

Alscher RG, Erturk N, Heath LS (2002) Role of superoxide dismutases (SODs) in controlling oxidative stress in plants. J. Exp. Biol. 53:1331-1341.

Anderson JM, Chow WS, Park Y-I (1995) The grand design of photosynthesis: acclimation of the photosynthetic apparatus to environmental cues. Photosyn. Res. 46:129139.

Apak R, Güçlü K, Demirata B, Özyürek M, Çelik SE, Bektaşoğlu B, Berker KI, Özyurt D (2007) Comparative evaluation of various total antioxidant capacity assays applied to phenolic compounds with the CUPRAC assay. Molecules 12:1496-1547.

Apel K, Hirt H (2004) Reactive oxygen species: metabolism, oxidative stress, and signal transduction. Annu. Rev. Plant Biol. 55:373-399.

Arnao M (2000) Some methodological problems in the determination of antioxidant activity using chromogen radicals: a practical case. Trends in Food Sci. Technol. 11:419421.

Aro EM, Virgin I, Andersson B (1993) Photoinhibition of photosystem II. Inactivation, protein damage and turnover. Biochim. Biophys. Acta 1143:113-134.

Asada K (1999) The water-water cycle in chloroplasts: scavenging of active oxygens and dissipation of excess photons. Annu. Rev. Plant Physiol. Plant Mol. Biol. 50: 601-639.

Asada K (2006) Production and scavenging of reactive oxygen species in chloroplasts and their functions. Plant Physiol. 141:391-396.

Baker NR (2011) Chlorophyll Fluorescence: A Probe of Photosynthesis In Vivo. Annu. Rev. Plant Biol. 59:89-113. 
Ballaré CL, Caldwell MM, Flint SD, Robinson SA, Bornman JF (2011) Effects of solar ultraviolet radiation on terrestrial ecosystems. Patterns, mechanisms, and interactions with climate change. Photochem. Photobiol. Sci. 10:226-241.

Bálo B, Hideg É, Váradi Gy, Vass I (1998) Damage of grapevine leaf photosynthesis by UV-B (280-320 nm) radiation in two cultivars of Vitis vinifera, In: Gy. Gabab (ed) Photosynthesis: Mechanisms and Effects, Kluwer Academic Publishers, Vol.III, 1998, pp. 2389-2392. ISBN 978-0-7923-5547-2

Barta Cs, Kálai T, Hideg K, Vass I, Hideg É (2004) Differences in the ROS generating efficacy of various ultraviolet wavelengths in detached spinach leaves. Funct. Plant Biol. $31: 23-28$.

Bassman JH, Robberecht R, Edwards GE (2001) Effects of enhanced UV-B radiation on growth and gas exchange in Populus deltoides Bartr. ex Marsh. Int. J. Plant Sci. 162 (1):103-110.

Benzie IFF, Strain JJ (1996) The ferric reducing ability of plasma (FRAP) as a measure of "antioxidant power": the FRAP assay, Anal. Biochem. 239:70-76.

Berkelaar EJ, Omrod DP, Hale BA (1994) The influence of photosynthetically active radiation on the effects of ultraviolet-B radiation on Arabidopsis thaliana. Photochem. Photobiol. 64:110-116.

Berli FJ, Moreno D, Piccoli P, Hespanhol-Viana L, Silva MF, Bressan-Smith R, Cavagnaro JB, Bottini R (2010) Abscisic acid is involved in the response of grape (Vitis vinifera L.) cv. Malbec leaf tissues to ultraviolet-B radiation by enhancing ultravioletabsorbing compounds, antioxidant enzymes and membrane sterols, Plant. Cell Environ. $33: 1-10$.

Beauchamp C, Fridovich I (1971) Superoxide dismutase: improved assays and an assay applicable to acrylamide gels. Anal. Biochem. 44:276-287.

Bidel LPR, Meyer S, Goulas Y, Cadot Y, Cerovic ZG (2007) Responses of epidermal phenolic compounds to light acclimation: in vivo qualitative and quantitative assessment using chlorophyll fluorescence excitation spectra in leaves of three woody species. J. Photochem. Photobiol. B. 88:163-179.

Bilger W, Björkman O (1990) Role of the xanthophyll cycle in photoprotection elucidated by measurements of light-induced absorbance changes, fluorescence and photosynthesis in leaves of Hedera canariensis. Photosynth. Res. 25:173-186.

Bilski P, Li MY, Ehrenshaft M, Daub ME, Chignell CF (2000) Vitamin B6 (pyridoxine) and it derivatives are effective singlet oxygen quenchers and potential fungal antioxidants. Photochem. Photobiol. 71: 129-134

Bolink EM, Van Schalkwijk I, Posthumus F, Van Hasselt PR (2003) Growth under UV-B radiation increases tolerance to high-light stress in pea and bean plants. Plant Ecology 154(1-2):149-156. 
Brosché M, Strid A. (2003) Molecular events following perception of ultraviolet-B radiation by plants. Physiol. Plant. 117:1-10.

Brown, B.A., Cloix, C., Jiang, G.H., Kaiserli, E., Herzyk, P., Kliebenstein, D.J., Jenkins, G.I. (2005). A UV-B-specific signaling component orchestrates plant UV protection. Proc. Natl. Acad. Sci. USA 102:18225-18230.

Cai Y, Luo O, Sun M, Corke H (2003) Antioxidant activity and phenolic compounds of 112 traditional Chinese medicinal plants associated with anticancer. Life Sciences $74: 2157-2184$.

Caldwell MM, Robberecht R, Flint SD (1983) Internal filters: Prospects for UV acclimation in higher plants. Physiol. Plant. 58:445-450.

Caldwell MM, Teramura AH, Tevini M (1989). The changing solar ultraviolet climate and the ecological consequences for higher plants. Trends Ecol. Evol. 4:363-366.

Carloni G, Iacovacci S, Sargiacomo M, Ravagnan G, Ponsetto A, Peschle C, Battaglia M (1993) Susceptibility of human liver cell cultures to hepatitis C virus infection. Archives of Virology 8:31-39.

Choi B, Roh KS (2003) UV-B radiation affects chlorophyll and activation of rubisco by rubisco activase in Canavalia ensiformis L. leaves. J. Plant Biol. 46(2):117-121.

Dai J, Mumper R (2010). Plant phenolics: extraction, analysis and their antioxidant and anticancer properties. Molecules, 15:7313-7352.

Dat J, Vandenabeele S, Vranová E, Van Montagu M, Inzé D, Van Breusegem $\mathbf{F}$ (2000) Dual action of the active oxygen species during plant stress responses. Cell. Mol. Life. Sci. 57:779-795.

del Río LA, Sandalio LM, Corpas FJ, Palma JM, Barroso JB (2006) Reactive oxygen species and reactive nitrogen species in peroxisomes. Production, scavenging, and role in cell signaling. Plant Physiol. 141:330-335.

Demmig-Adams B, Adams WW (1993) The xanthophyll cycle, protein turnover, and the high light tolerance of sun-acclimated leaves. Plant Physiol. 103(4):1413-1420.

Denslow SA, Walls AA, Daub ME (2005) Regulation of biosynthetic genes and antioxidant properties of vitamin B6 vitamers during plant defense responses. Physiological and Molecular Plant Pathology 66(6):244-255

Dietz KJ (2003) Redox control, redox signaling, and redox homeostasis in plant cells. International Reviews in Cytology 228:141-193.

Dietz KJ, Jacob S, Oelze ML, Laxa M, Tognetti V, de Miranda SM, Baier M, Finkemeier I (2006). The function of peroxiredoxins in plant organelle redox metabolism. J Exp Bot 57(8):1697-1709. 
European Medicines Agency (2011) Assessment report on Tilia cordata Miller, Tilia platyphyllos Scop., Tilia $x$ vulgaris Heyne or their mixtures, flos. EMA/HMPC/337067/2011

Retrieved from: http://www.ema.europa.eu/docs/en_GB/document_library/Herbal__HMPC_assessment_report/2011/10/WC500116851.pdf

Ewart AJ (1896) On assimilatory inhibition in plants. J Linnean Soc Bot 31:364-461.

Ewing JF, Janero DR. (1995) Microplate superoxide dismutase assay employing a nonenzymatic superoxide generator. Anal Biochem. 232(2):243-248.

Fehér B, Kozma-Bognár L, Kevei É, Hajdu A, Binkert M, Davis SJ, Schaafer E, Ulm R, Nagy F (2011) Functional interaction of the circadian clock and UV RESISTANCE LOCUS 8-controlled UV-B signaling pathways in Arabidopsis thaliana. Plant J. 67:37-48.

Fischer BB, Hideg É, Krieger-Liszkay A (2013) Production, detection and signaling of singlet oxygen in photosynthetic organisms. Antioxid. Redox Signal. -Not available-, ahead of print. doi:10.1089/ars.2012.5124.

Flint, S.D., Caldwell, M.M. (2003) A biological spectral weighting function for ozone depletion research with higher plants. Physiol. Plantarum 117(1):137-144.

Foyer CH, Bloom AJ, Queval G, Noctor G (2009) Photorespiratory metabolism : genes, mutants, energetics, and redox signaling. Annu. Rev. Plant Biol. 60:455-484.

Foyer CH, Noctor G (2005) Redox homeostasis and antioxidant signaling: a metabolic interface between stress perception and physiological responses. Plant Cell 17:1866-1875.

Foyer CH, Noctor G (2009) Redox regulation in photosynthetic organisms: signaling, acclimation, and practical implications Antioxidants and Redox Signaling 11:861-905.

Foyer CH, Noctor G (2011) Ascorbate and glutathione : the heart of the redox hub. Plant Physiol. 155:2-18.

Foyer CH, Shigeoka (2011) Understanding oxidative stress and antioxidant functions to enhance photosynthesis. Plant Physiol. 155:93-100.

Franklin KA, Larner VS, Whitelam GC (2005) The signal transducing photoreceptors of plants. Int. J. Dev. Biol. 49:653-664.

Frankel E, Meyer AS (2000) The problems of using one-dimensional methods to evaluate multifunctional food and biological antioxidants. Journal of Science of Food and Agriculture 80:1925-1941.

Frohnmeyer H, Staiger D (2003) Ultraviolet-B radiationmediated responses in plants: balancing damage and protection. Plant Physiol. 133:1420-1428.

Fu Y, Krasnovsky AA Jr, Foote CS (1993) Singlet oxygen dimol-sensitized luminescence from thermally generated singlet oxygen. Journal of the American Chemical Society 115 (22):10282-10285. 
Gaspar T, Franck T, Bisbis B, Kevers C, Jouve L, Hausman JF, Dommes J (2002) Concepts in plant stress physiology. Application to plant tissue cultures. Plant Growth Reg. 37:263-285.

Genty B, Briantais J-M, Baker NR (1989) The relationship between the quantum yield of photosynthetic electron transport and quenching of chlorophyll fluorescence. Biochim. Biophys. Acta 990(1):87-92.

Ghiselli A, Serafini M, Natela F, Scaccini C (2000) Total antioxidant capacity as a tool to assess redox status: critical view and experimental data. Free Rad. Biol. Med. 29:11061114.

Giannapolitis CN, Ries, S. K. (1977) Superoxide dismutases. I. Occurrence in higher plants. Plant Physiol. 59:309-314.

Gill SS, Tuteja N (2010) Reactive oxygen species and antioxidant machinery in abiotic stress tolerance in crop plants. Plant Physiol. Biochem. 48:909-930.

Götz M, Albert A, Stich S, Heller W, Scherb H, Krins A, Langebartels C, Seidlitz HK, Ernst D (2010) PAR modulation of the UV-dependent levels of flavonoid metabolites in Arabidopsis thaliana (L.) Heynh. leaf rosettes: cumulative effects after a whole vegetative growth period. Protoplasma 243:95-103.

Grace SC, Logan BA (1996) Acclimation of foliar antioxidant systems to growth irradiance in three broad-leaved evergreen species. Plant Physiol. 112:1631-1640.

Gutteridge JM, Halliwell B (1988) The deoxyribose assay: an assay both for 'free' hydroxyl radical and for site-specific hydroxyl radical production. Biochem. J. 253:932940.

Hallik L, Niinemets U, Kull O (2012) Photosynthetic acclimation to light in woody and herbaceous species: a comparison of leaf structure, pigment content and chlorophyll fluorescence characteristics measured in the field. Plant Biol. 14:88-99.

Halliwell B (2006) Reactive species and antioxidants. Redox biology is a fundamental theme of life aerobic life. Plant Physiol. 141:312-322.

Halliwell B, Gutteridge JMC (1999) Free Radicals in Biology and Medicine, 3rd edn. Oxford: Clarendon Press.

Harborne, J.B., Williams, C.A. (2000) Advances in flavonoid research since 1992. Phytochemistry 55: 481-504

Havaux M, Ksas B, Szewczyk A, Rumeau D, Franck F, Caffarri S, Triantaphylidès C. (2009) Vitamin B6 deficient plants display increased sensitivity to high light and photooxidative stress. BMC Plant Biol. 9:130.

Hectors K, Prinsen E, De Coen W, Jansen MAK, Guisez Y (2007) Arabidopsis thaliana plants acclimated to low dose rates of ultraviolet B radiation show specific changes in 
morphology and gene expression in the absence of stress symptoms. New Phytologist $175: 255-270$.

Heijde M, Ulm R (2012) UV-B photoreceptor-mediated signaling in plants. Trends Plant Sci.17:230-237.

Heim KE, Tagliaferro AR, Bobilya DJ (2002) Flavonoid antioxidants: chemistry, metabolism and structure-activity relationships. J. Nutr. Biochem. 13:572-584.

Hernández I, Alegre L, Van Breusegem F, Munne-Bosch S (2009). How relevant are flavonoids as antioxidants in plants? Trends Plant Sci. 14:125-132.

Hideg É, Barta C, Kálai T, Vass I, Hideg K, Asada K (2002) Detection of singlet oxygen and superoxide with fluorescent sensors in leaves under stress by photoinhibition or UV radiation. Plant Cell Physiol. 43:1154-1164.

Hideg É., Jansen MAK, Strid Å. (2013) UV-B, ROS and stress: inseparable companions or loosely linked associates? Trends Plant Sci. 18:107-115.

Hideg É, Kálai T, Hideg K, Vass I (2000) Do oxidative stress conditions impairing photosynthesis in the light manifest as photoinhibition? Philos. T. R. Soc. B. 355:15111516.

Hideg É, Majer P (2010) Factors contributing to the high light tolerance of leaves in vivo - Involvement of photo-protective energy dissipation and singlet oxygen scavenging. Acta Biol. Hung. 61.(Suppl.):49-60.

Hideg É, Vass I (1996) UV-B induced free radical production in plant leaves and isolated thylakoid membranes. Plant Science 115(2):251-260

Hideg É, Vass I, Kálai T, Hideg K (2000) Singlet oxygen detection with sterically hindered amine derivatives in plants under light stress. Methods Enzymol. 319:77-85.

Hofmann RW, Swinny EE, Bloor SJ, Markham KR, Ryan KG, Campbell BD, Jordan BR, Fountain DW (2000) Responses of nine Trifolium repens L. populations to ultraviolet-B radiation: differential flavonol glycoside accumulation and biomass production. Ann. Bot. 86:527-537.

Hu JP, Calomme M, Lasure A, De Bruyne T, Peters L, Vlietinck A, Van den Berghe DA (1995) Structure-activity relationship of flavonoids with superoxide scavenging activity. Biol Trace Element Res. 47:327-331.

Huang D, Ou B, Prior RL (2005) The Chemistry behind Antioxidant Capacity Assays. J. Agric. Food Chem. 53:1841-1856.

Hossain MB, Brunton NP, Barry-Ryan C, Martin-Diana AB, Wilkinson M (2008) Antioxidant activity of spice extracts and phenolics in comparison to synthetic antioxidants. Rasayan J. Chem. 1:751-756. 
Husain SR, Cillard J, Cillard P (1987) Hydroxyl radical scavenging activity of flavonoids. Phytochemistry 26:2489-2491.

Ibañez S, Rosa M, Hilal M, González JA, Prado FE (2008) Leaves of Citrus aurantifolia exhibit a different sensibility to solar UV-B radiation according to development stage in relation to photosynthetic pigments and UV-B absorbing compounds production, $\mathrm{J}$. Photochem. Photobiol. B. 90:163-169.

Jaakola L, Määttä-Riihinen K, Kärenlampi S, Hohtola A (2004) Activation of flavonoid biosynthesis by solar radiation in bilberry (Vaccinium myrtillus L.) leaves. Planta 218:721-728.

Jäger AK, Saaby L (2011) Flavonoids and the CNS. Molecules 16(2):1471-1485.

Jambunathan N (2010) Determination and detection of reactive oxygen species (ROS), lipid peroxidation, and electrolyte leakage in plants. Methods Mol. Biol. 639:292-298.

Jansen MAK, Gaba V, Greenberg BM (1998) Higher plants and UV-B radiation: balancing damage, repair and acclimation. Trends Plant Sci. 3:131-135.

Jansen MAK (2002) Ultraviolet-B radiation effects on plants: induction of morphogenic responses Physiol. Plant. 116:423-429.

Jansen MAK, Van Den Noort RE (2000) Ultraviolet-B radiation induces complex alterations in stomatal behaviour. Physiol. Plantarum 110(2):189-194.

Jenkins GI (2009) Signal transduction in responses to UV-B radiation. Annu. Rev. Plant Biol. 60:407-31.

Jung H-S, Niyogi KK (2006) Molecular Analysis of Photoprotection of Photosynthesis. In: B. Demmig-Adams, William W. Adams III and A.K. Mattoo (eds), Photoprotection, Photoinhibition, Gene Regulation, and Environment, 127-143. 2006 Springer. Printed in The Netherlands.

Kautsky H, Hirsch A. (1931) Neue Versuche zur Kohlensäureassimilation, Naturwissenschaften 19:964-964.

Kálai T, Hideg É., Vass I, Hideg K (1998) Double (fluorescent and spin) sensors for detection of reactive oxygen species in the thylakoid membrane. Free Rad. Biolo. Med. 24:649-652.

Karuppanapandian T, Wang HW, Prabakaran N, Jeyalakshmi K, Kwon M, Manoharan K, Kim W (2011) 2,4-dichlorophenoxyacetic acid-induced leaf senescence in mung bean (Vigna radiata L. Wilczek) and senescence inhibition by co-treatment with silver nanoparticles. Plant Physiol. Biochem. 49:168-177

Katalinic, V., M. Milos, T. Kulisic and M. Jukic (2006) Screening of 70 medicinal plant extracts for antioxidant capacity and phenols. Food Chem. 94: 550-557. 
Keren N, Berg A, van Kan PJM, Levanon H and Ohad I (1997) Mechanism of Photosystem II photoinactivation and D1 protein degradation at low light: the role of back electron flow. Proc. Natl. Acad. Sci. USA 94:1579-1584.

Keren N, Krieger-Liszkay A (2011) Photoinhibition: molecular mechanisms and physiological significance. Physiol. Plantarum 142:1-5.

Keskitalo J, Bergquist G, Gardström P, Jansson S (2005) A cellular time table of autumn senescence. Plant Physiol. 139:1635-1648.

Khanduja KL, Bhardwaj A (2003) Stable free radical scavenging and antiperoxidative properties of resveratrol compared in vitro with some other bioflavonoids. Indian $\mathrm{J}$ Biochem Biophys. 40(6):416-422.

Khanna-Chopra R. (2012) Leaf senescence and abiotic stresses share reactive oxygen species-mediated chloroplast degradation. Protoplasma. 249(3):469-81.

Kırca A, Arslan E (2008) Antioxidant capacity and total phenolic content of selected plants from Turkey. Int. J. Food Sci. Techn. 43(11):2038-2046.

Klughammer C, Schreiber U (2008) Complementary PS II quantum yields calculated from simple fluorescence parameters measured by PAM fluorometry and the saturation pulse method. PAM Appl. Notes 1:27-35.

Kolb CA, Käser MA, Kopecký J, Zotz G, Riederer M, Pfündel EE (2001) Effects of natural intensities of visible and ultraviolet radiation on epidermal ultraviolet screening and photosynthesis in grape leaves. Plant Physiol. 127:863-875.

Kosztolányi D (1927) Esti már megint jót tesz. Elbeszélés IV. Nyugat 24.

Kraljić I, El Mohsni S (1978) A new method for the detection of singlet oxygen in aqueous solutions. Photochem. Photobiol. 28:577-581.

Krieger-Liszkay A, Kos PB, Hideg E. (2011) Superoxide anion radicals generated by methylviologen in photosystem I damage photosystem II. Physiologia Plantarum 142:1725 .

Krizek DT (2004) Influence of PAR and UV-A in determining plant sensitivity and photomorphogenic responses to UV-B radiation. Photochem Photobiol 79:307-315

Kuzniak E (2002) Transgenic Plants: An Insight into Oxidative Stress Tolerance Mechanisms. Acta Physiol. Plant. 24:97-113.

Lemaire SD, Michelet L, Zaffagnini M, Massot V, Issakidis-Bourguet E. (2007) Thioredoxins in chloroplasts. Curr. Genet. 51:343-365.

Levitt J (1972) Responses of plants to environmental stresses. Academic Press, New York 
Levizou E, Manetas Y (2002) Spectrophotometric assessment of leaf UV-B absorbing compounds and chemically determined total phenolic levels are strongly correlated. Can. J. Botany 80(6):690-694.

Li Z, Wakao S, Fischer BB, Niyogi KK (2009) Sensing and responding to excess light. Annu. Rev. Plant Biol. 60:239-260.

Li J, Ou-Lee T-M, Raba R, Amundson RG, Last RL (1993) Arabidopsis flavonoid mutants are hypersensitive to UV-B irradiation. Plant Cell 5:171-179.

Lichtenthaler, H. K. (1998), The Stress Concept in Plants: An Introduction. Ann. NY Acad. Sci. 851:187-198.

Logan BA, Kornyeyev D, Hardison J, Holaday AS (2006) The role of antioxidant enzymes in photoprotection. Photosynth. Res. 88:119-132.

Mackerness AH, John CF, Jordan B, Thomas B (2001) Early signaling components in ultraviolet-B responses: Distinct roles for different reactive oxygen species and nitric oxide. FEBS Letters 489(2-3):237-242.

Macpherson AN, Telfer A, Barber J, Truscott TG (1993) Direct detection of singlet oxygen from isolated Photosystem II reaction centres. Biochim. Biophys. Acta 1143:301309.

Majer P, Hideg É (2012a) Developmental stage is an important factor that determines the antioxidant responses of young and old grapevine leaves under UV irradiation in a greenhouse. Plant Physiol. Biochem. 50:15-23.

Majer P, Hideg É (2012b) Existing antioxidant levels are more important in acclimation to supplemental UV-B irradiation than inducible ones: Studies with high light pretreated tobacco leaves. Emirates Journal of Food and Agriculture 24(6):598-606.

Majer P, Stoyanova S., Hideg É (2010) Do leaf total antioxidant capacities (TAC) reflect specific antioxidant potentials? - A comparison of TAC and reactive oxygen scavenging in tobacco leaf extracts. J. Photochem. Photobiol. B. 100(1):38-43.

Maxwell K, Johnson GN (2000) Chlorophyll fluorescence: a practical guide. J. Exp. Bot. $51: 659-668$.

McCord JM, Fridovich I (1969) Superoxide dismutase: an enzymic function for erythrocuprein (hemocuprein). J. Biol. Chem. 244:6049-6055.

Mehler AH (1951) Studies on the reactions of illuminated chloroplasts. 11. Stimulation on inhibition of the reaction with molecular oxygen. Arch. Biochem. Biophys. 34:339-351.

Middleton EM, Teramura AH (1993) The role of flavonol glycosides and carotenoids in protecting soybean from ultraviolet-B damage. Plant Physiol. 103:741-752.

Miller N.J., Rice-Evans C.A., Davies M.J., Gopinathan V., Milner A (1993) A novel method for measuring antioxidant capacity and its application to monitoring the antioxidant status in premature neonates. Clinical Science 84:407-412. 
Miller NJ, Sampson J, Candeias LP, Bramley PM, Rice-Evans CA (1996) Antioxidant activities of carotenes and xanthophylls. FEBS Letters 384:240-242

Mirecki RM, Teramura AH (1984) Effects of ultraviolet-B irradiance on soybean. V. The dependence of plant sensitivity on the photosynthetic photon flux density during and after leaf expansion. Plant Physiol. 74: 475-480.

Mittler R (2002) Oxidative stress, antioxidants and stress tolerance. Trends Plant Sci. 7:405-410.

Montoro P, Braca A, Pizza C, De Tommasi N (2005) Structure-antioxidant activity relationships of flavonoids isolated from different plant species. Food Chem. 92:349-355.

Møller IM, Jensen PE, Hansson A (2007) Oxidative modifications to cellular components in plants. Annu. Rev. Plant Biol. 58:459-481.

Munné-Bosch S. (2007) Alpha-tocopherol: a multifaceted molecule in plants. Vitam. Horm. 76:375-392.

Müller P, Li XP, Niyogi KK (2001) Non-photochemical quenching. A response to excess light energy. Plant Physiol. 125: 1558-1566

Niyogi KK (1999) Photoprotection revisited: genetic and molecular approaches. Annu. Rev. Plant Physiol. Plant Mol. Biol. 50:333-359.

Noctor G, Foyer CH. (1998) Ascorbate and glutathione: keeping active oxygen under control. Annu. Rev. Plant Physiol. Plant Mol. Biol. 49:249-279.

Noctor G, Mhamdi A, Chaouch S, Han Y, Neukermans J, Queval G, Foyer CH (2012) Glutathione in plants : an integrated overview. Plant Cell Environ. 35: 454-484.

Nogues S, Allen DJ, Morison JIL, Baker NR (1999) Characterization of stomatal closure caused by ultraviolet-B radiation. Plant Physiol. 121:489-496.

Norman I. Krinsky NI (1989) Antioxidant functions of carotenoids. Free Rad. Biol. Med. 7(6):617-635.

Ort DR (2001) When there is too much light. Plant Physiol. 125:29-32.

Peltier G, Cournac L (2002) Chlororespiration. Annu. Rev. Plant Physiol. Plant Mol. Biol. 53:523-550.

Perez-Jimenez J, Saura-Calixto F (2006) Antioxidant capacity of dietary polyphenols determined by ABTSassay: a kinetic expression of the results. Int. J. Food Sci. Technol. 43: 185-191.

Pontin MA, Piccoli PN, Francisco R, Bottini R, Martinez-Zapater JM, Lijavetzky D (2010) Transcriptome changes in grapevine (Vitis vinifera L.) cv. Malbec leaves induced by ultraviolet-B radiation, BMC Plant Biol. 10:224-236. 
Pospíšil P (2009) Production of reactive oxygen species by photosystem II. Biochim. Biophys. Acta 1787:1151-1160.

Poulson ME, Donahue RA, Konvalinka J, Boeger MRT (2002) Enhanced tolerance of photosynthesis to high-light and drought stress in Pseudotsuga menziesii seedlings grown in ultraviolet-B radiation. Tree Physiol. 22:829-838.

Powles SB (1984) Photoinhibition of photosynthesis induced by visible light. Annual Rev. Plant Physiol. 35:15-44.

Ratty AK, Das NP (1988). Effects of flavonoids on non-enzymic lipid peroxidation: Structure activity relationship. Biochem. Med. Metab. B. 39:69-79.

Re R, Pellegrini N, Pannala A, Yang M, Rice-Evans C (1999) Antioxidant activity applying an improved ABTS radical cation decolorization assay. Free Rad. Biol. Med. 26:1231-1237.

Reifenrath K, Müller C (2007) Species-specific and leaf-age dependent effects of ultraviolet radiation on two Brassicaceae. Phytochemistry 68:875-885.

Rice-Evans C, Miller NJ (1994) Total antioxidant status in plasma and body fluids. Methods Enzymol. 234:279-293.

Rice-Evans CA, Miller NJ, Bolwell PG, Bramley PM, Pridham JB (1995) The relative antioxidant activities of plant-derived polyphenolic flavonoids. Free Radical Res. 22:375383.

Rice-Evans CA, Miller NJ, Paganga G (1996) Structure-antioxidant activity relationship of flavonoids and phenolic acids. Free Rad. Biol. Med.20:933-956.

Ryan KG, Markham KR, Bloor SJ, Bradley JM, Mitchell KA, Jordan BR (1998) UV$B$ radiation induced increase in quercetin : kaempferol ratio in wild-type and transgenic lines of petunia. Photochem. Photobiol. 68:323-330.

Ryan KG, Swimmy EE, Winefield C, Markham KE (2001) Flavonoids and UV photoprotection in Arabidopsis mutants. Z. Naturforsch. 56:745-754.

Sagi M. Fluhr R. (2006): Production of reactive oxygen species by plant NADPH oxidases. Plant Physiol. 141:336-340.

Sakihama Y, Cohen MF, Grace SC, Yamasaki H. (2002) Plant phenolic antioxidant and prooxidant activities: phenolics-induced oxidative damage mediated by metals in plants. Toxicology 177(1):67-80.

Saunders JA, McClure JW (1976) The distribution of flavonoids in chloroplasts of twenty-five species of vascular plants. Phytochemistry 15:809-811.

Schmidt S, Zietz M, Schreiner M, Rohn S, Kroh LW, Krumbein A (2010) Genotypic and climatic influences on the concentration and composition of flavonoids in kale (Brassica oleracea var. sabellica). Food Chem. 119:1293-1299. 
Schreiber U, Schliwa U, Bilger W (1986) Continuous recording of photochemical and non-photochemical chlorophyll fluorescence quenching with a new type of modulation fluorometer. Photosynth Res 10: 51-62

Sharma R, Sharma G, Sharma M (2012) Anti-Malassezia furfur activity of essential oils against causal agent of Pityriasis versicolor disease Afr. J. Pharmacy Pharmacol., 6:979983.

Shulaev, V., Oliver. D.J. (2006) Metabolic and Proteomic Markers for Oxidative Stress. New Tools for Reactive Oxygen Species Research. Plant Physiol. 141(2):367-372.

Sicora C, Máté Z, Vass I (2003) The interaction of visible and UV-B light during photodamage and repair of photosystem II. Photosynth Res. 75:127-137.

Smirnoff N (2000) Ascorbic acid: metabolism and functions of a multi-facetted molecule. Curr. Opin. Plant Biol. 3:229-235.

Šnyrychová I, Hideg É (2007) The first application of terephthalate fluorescence for highly selective detection of hydroxyl radicals in thylakoid membranes, Funct. Plant Biol. 34:1105-1111.

Song YG, Liu B, Wang LF, Li MH, Liu Y (2006) Damage to the oxygen-evolving complex by superoxide anion, hydrogen peroxide, and hydroxyl radical in photoinhibition of photosystem II. Photosynth Res. 90(1):67-78.

Stephanson CJ, Stephanson AM, Flanagan GP (2003) Evaluation of hydroxyl radicalscavenging abilities of silica hydride, an antioxidant compound, by a Fe ${ }^{+}$-EDTA-induced 2-hydroxyterephthalate fluorometric analysis, J. Med.Food 6:249-253.

Sun T, Tanumihardjo SA. (2007) An integrated approach to evaluate food antioxidant capacity. J Food Sci. 72(9):R159-165.

Sunkar R, Bartels D, Kirch HH (2003). Overexpression of a stress-inducible aldehyde dehydrogenase gene from Arabidopsis thaliana in transgenic plants improves stress tolerance. Plant J. 35:452-464.

Szőllősi R, Szőllősi-Varga I (2002) Total antioxidant power in some species of Labiatae, Adaptation of FRAP method, Acta Biol. Szeg. 46:125-127.

Suzuki N, Koussevitzky S, Mittler R, Miller G (2012) ROS and redox signalling in the response of plants to abiotic stress. Plant Cell Environ. 35:259-270.

Takeuchi A, Yamaguchi T, Hidema J, Strid A,Kumagai T (2002) Changes in synthesis and degradation of Rubisco and LHCII with leaf age in rice (Oryza sativa L.) growing under supplementary UV-B radiation. Plant Cell Environ. 25:695-706.

Toker G, Aslan M, Yeşilada E, Memişoğlu M, Ito S (2001) Comparative evaluation of the flavonoid content in officinal Tiliae flos and Turkish lime species for quality assessment. Biomed. Anal. 26:111-121. 
Tournaire C, Croux S, Maurette MT, Beck I, Hocquaux M, Braun AM, Oliveros E (1993) Antioxidant activity of flavonoids: efficiency of singlet oxygen $(1 \Delta \mathrm{g})$ quenching. $\mathrm{J}$. Photochem. Photobiol. 19:205-215.

Triantaphylidès C, Havaux M (2009) Singlet oxygen in plants: production, detoxification and signaling. Trends Plant Sci. 14(4):219-228.

Van Breusegem F, Dat JF (2006) Reactive oxygen species in plant cell death. Plant Physiol. 141, 384-390.

Van Breusegem F, Vranová E, Dat J, Inzé D (2001) The role of active oxygen species in plant signal transduction. Plant Sci. 161:405-414.

Vandelle E, Delledonne M. (2011) Peroxynitrite formation and function in plants. Plant Sci. 181(5):534-539.

Vass I, Styring S, Hundal T, Koivuniemi A, Aro EM, Andersson B (1992) Reversible and irreversible intermediates during photoinhibition of photosystem II. Stable reduced QA species promote chlorophyll triplet formation. PNAS USA 89:1408-1412.

Vass I, Sass L, Spetea C, Bakou A, Ghanotakis D, Petrouleas V (1996) UV-B induced inhibition of photosystem II electron transport studied by EPR and chlorophyll fluorescence. Impairment of donor and acceptor side components. Biochemistry 35:89648973.

Veitch NC (2004) Structural determinants of plant peroxidase function. Phytochem Rev. $3: 3-18$.

Velioglu, Y.S, Mazza, G., Gao, L., Oomah, B.D. (1998) Antioxidant activity and total phenolics in selected fruits, vegetables and grain products, J. Agr. Food Chem. 46:41134117.

Walters RG (2005) Towards an understanding of photosynthetic acclimation. J. Exp. Bot. 56(411):435-447.

Winkel-Shirley B (2002) Biosynthesis of flavonoids and effects of stress. Curr. Opin. Plant Biol. 5:218-223.

Wojtaszek P (1997) Oxidative burst: an early plant response to pathogen. Biochem. J. 322:681-692.

Wu X, Beecher GR, Holden JM, Haytowitz DB, Gebhardt SE, Prior RL (2004) Lipophilic and hydrophilic antioxidant capacities of common foods in the United States. J. Agr. Food Chem. 52:4026-4037.

Wu D, Hu Q, Yan Z, Chen W, Yan C, Huang X, Zhang J, Yang P, Deng H, Wang J, Deng X, Shi Y (2012) Structural basis of ultraviolet-B perception by UVR8. Nature 484: 214-219. 
Yang CM, Chang KW, Yin MH, Huang HM (1998) Methods for the determination of the chlorophylls and their derivatives. Taiwania 43:116-122.

Young I (2001) Measurement of total antioxidant capacity. J. Clin. Pathol. 54(5):339.

Younis ME, Hasaneen MNA, Abdel-Aziz HMM (2010) An enhancing effect of visible light and UV radiation on phenolic compounds and various antioxidants in broad bean seedlings. Plant Signal. Behav. 5(10):1197-1203.

Zaprometov MN, Nikolaeva TN (2003) Chloroplasts isolated from kidney bean leaves are capable of phenolic compound biosynthesis. Russ. J. Plant Physiol. 50:623-626.

Zentgraf U, Hemleben V (2008) Molecular cell biology: Are reactive oxygen species regulators of leaf senescence? In: Progress in Botany, Vol. 69, Springer Verlag, Berlin, Heidelberg, New York, pp 117-137.

Zhang WJ, Björn LO (2009) The effect of ultraviolet radiation on the accumulation of medicinal compounds in plants. Fitoterapia 80:207-218.

Zimmerman P, Zentgraf U (2005) The Correlation between oxidative stress and leaf senescence during plant development. Mol. Cell. Biol. Lett. 10:515-534.

Ziska LH, Teramura AH, Sullivan JH and A McCoy (1993) Influence of ultraviolet-B (UV-B) radiation on photosynthetic and growth characteristics in field-grown cassava (Manihot esculentum Crantz). Plant Cell Environ. 16:73-80. 


\section{PUBLIKÁCIÓS LISTA}

\section{A dolgozathoz kapcsolódó bírált folyóirat-közlemények:}

Majer P, Stoyanova S, Hideg É (2010) Do leaf total antioxidant capacities (TAC) reflect specific antioxidant potentials? - A comparison of TAC and reactive oxygen scavenging in tobacco leaf extracts. Journal of Photochemistry and Photobiology B: Biology 100(1):3843.

\section{IF: 2,116}

Hideg É, Majer P (2010) Factors contributing to the high light tolerance of leaves in vivo - Involvement of photo-protective energy dissipation and singlet oxygen scavenging. Acta Biologica Hungarica 61.(Suppl.): 49-60.

IF: 0,793

Majer P, Hideg É (2012a) Developmental stage is an important factor that determines the antioxidant responses of young and old grapevine leaves under UV irradiation in a greenhouse. Plant Physiology and Biochemistry 50:15-23.

IF: $\mathbf{2 , 4 0 2}$

Majer P, Hideg É (2012b) Existing antioxidant levels are more important in acclimation to supplemental UV-B irradiation than inducible ones: Studies with high light pretreated tobacco leaves. Emirates Journal of Food and Agriculture 24(6): 598-606.

Majer P, Neugart S, Krumbein A, Schreiner M, Hideg É (kézirat) Singlet oxygen scavenging by leaf flavonoids contributes to sunlight acclimation in Tilia platyphyllos.

\section{Egyéb bírált folyóirat-közlemények:}

Nagy B, Majer P, Mihály R, Dudits D, Horváth VG (2011) Transient and transgenic approaches for functional testing of candidate genes in barley. Acta Biologica Szegediensis. 55(1): 129-133.

Majer P, Sass L., Horváth VG, Hideg É (2010) Leaf hue measurements offer a fast, high-throughput initial screening of photosynthesis in leaves. Journal of Plant Physiology, 167(1):74-76.

IF: 2,677

Zok A, Oláh R, Hideg É, Horváth VG, Kós PB, Majer P, Váradi Gy, Szegedi E (2010) Effect of Medicago sativa ferritin gene on stress tolerance in transgenic grapevine. Plant Cell, Tissue and Organ Culture. 100(3):339-344

IF: $\mathbf{1 , 2 4 3}$ 


\section{Konferencia kivonatok}

Majer P, Neugart S, Krumbein A, Schreiner M, Hideg É (2012) Acclimation to high light in linden leaves is aided by singlet oxygen neutralizing flavonoids. Abstracts of the Plant Biology Congress, 29 July-3 August 2012, Freiburg, Germany, pp. 370-371.

Hideg É, Majer P, Czégény Gy, Sándor Gy, Poage M, Dix PJ (2012) Consequences of enhanced chloroplast SOD activity on the acclimation of leaves to supplemental UV-B. Abstracts of the Plant Biology Congress, 29 July-3 August 2012, Freiburg, Germany, pp. 337.

Majer P, Hideg É (2012) Preceding high light acclimation promotes toleration of supplemental UV-B radiation via enhancing base antioxidant levels. Abstracts of the COST Action FA0906 WG3 mini-conference „Plant responses to ultraviolet radiation roles of antioxidants and pro-oxidants" 2-3 February 2012, Copenhagen, Denmark, pp. 12.

Majer P, Neugart S, Krumbein A, Schreiner M, Hideg É (2011) Living under the sun: singlet oxygen neutralizing by flavonoids in sun and shade linden leaves. Abstracts of the COST Action UV4growth mini-conference „MetabolUV - Interactive effects of UV-B radiation with abiotic and biotic factors" 23-24 November 2011, Cork, Ireland

Majer P, Neugart S, Krumbein A, Schreiner M, Hideg É (2011) Singlet oxygen scavenging in linden leaves. (International Training Course Alumni Conference „Multidisciplinary Approaches to Biological Problems”, 1-3 September 2011, Szeged, Hungary

Majer P, Hideg É (2011) Age related differences in antioxidant responses of grapevine (Vitis vinifera L.) leaves to supplemental UV-B radiation. Abstracts of the 10th International Conference on Reactive Oxygen and Nitrogen Species in Plants, 5-8 July 2011, Budapest, Hungary, pp. 115.

Majer P, Hideg É (2011) Are young ones more vigorous? A comparative study of photosynthesis and antioxidant responses of younger and older Vitis leaves under UV-B radiation in a green-house experiment. Abstracts of the 1st Annual Meeting of COST Action FA0906 UV4growth, 7-9 February 2011, Szeged, Hungary, ISBN 978-963-508606-1, pp. 21.

Majer P, Sass L, Lelley T, Cseuz L, Vass I, Dudits D, Pauk J (2008) Testing drought tolerance of wheat by a complex stress diagnostic system installed in greenhouse. Acta Biologica Szegediensis 52(1):97-100.

Jancsó M, Majer P, Lantos C, Simon-Kiss I, Dudits D, Pauk J (2007) Diagnostic system for detection of drought tolerant rice genotypes. Proceedings of the 4th International Temperate Rice Conference, June 25-28, 2007, Novara, Italy, pp. 330-331. 


\section{Könyvfejezetek}

Sass L, Majer P, Hideg É (2012) Leaf hue measurements: a high-throughput screening of chlorophyll content. In: Methods in Molecular Biology vol. 918: High-Throughput Phenotyping in Plants: Methods and Protocols. Ed: J. Normanly. Humana Press. ISBN 978-1-61779-994-5 


\section{ÖSSZEFOGLALÁS}

A növényi szervezetek akklimációs folyamatok révén nagy mértékben képesek alkalmazkodni a változó fényviszonyokhoz. Ez magában foglalja mind a napfény nagy intenzitású fotoszintetikusan aktív komponensének (PAR), mind pedig az ultraibolya (UV) sugárzás Földre eljutó részének (290-400nm) lehetséges káros hatásai elleni védelmet. Bár mindkét napfény komponens szükséges vagy hasznos a növények fejlődéséhez és életéhez mint energiaforrás (PAR) és információhordozó (PAR és UV), oxidatív stresszorként is megjelenhetnek. Az akklimációs folyamatok egyik fontos eleme ennek elkerülése, a prooxidáns-antioxidáns egyensúly fenntartásával. A látható fény magas intenzitásai a fotoszintézis fény általi gátlásához, fotoinhibícióhoz vezethetnek, amely során különbözö mechanizmusok hatására a növényi sejtekben megnő a reaktív oxigén származékok (ROS) koncentrációja. A ROS-ok (szuperoxid-gyökanion, $\mathrm{O}_{2}{ }^{-}$; hidrogén-peroxid, $\mathrm{H}_{2} \mathrm{O}_{2}$; hidroxilgyök, ${ }^{\circ} \mathrm{OH}$; szinglett oxigén, ${ }^{1} \mathrm{O}_{2}$ ) potenciálisan veszélyes molekulák, amelyek láncreakciószerü terjedésükkel további gyökös, vagy nem gyökös természetü reaktív formákat képeznek, ami a sejtalkotók degradációjához, lipidperoxidációhoz, és az oxidatív stresszen keresztül végül a sejt pusztulásához vezethet. A ROS-ok fokozott produkciója a növények erőforrás-átcsoportosítását igénylő más abiotikus környezeti változásokra is jellemző folyamat, ami fokozhatja a fotoinhibíciót. Azonban a növényekben hatékony mechanizmusok müködnek a ROS-ok keletkezésének megelőzésére és semlegesítésükre. Az előbbi főképp a preventív (energia disszipációs) utakon, míg az utóbbi az antioxidáns rendszeren keresztül valósul meg, amely enzimek és nemenzimatikus vegyületek többszintü, együttműködő hálózatát jelenti. Valójában (a ROS-okat és termékeiket magában foglaló) prooxidánsoknak és az antioxidánsoknak egyfajta egyensúlyi állapota, vagyis a sejt redox homeosztázisának fenntartására való törekvés a kulcsa a környezeti jelekre, mint stresszorokra adott válaszreakciónak. A stresszorok közvetett (legjellemzőbben hormonális) utakon, illetve a ROS-ok maguk is képesek indukálni az antioxidáns védelmet, így segíthetnek egy új egyensúly beállításában, ami a megváltozott környezeti feltételekhez való akklimációhoz vezet. A magas UV dózisok közvetlenül mérhető ROS keletkezéséhez és oxidatív stresszhez vezetnek, míg az alacsonyabb dózisú, krónikus UV-szintek feltehetően alacsony koncentrációjú ROS közvetítette jelátviteli utakon keresztül részt vehetnek az akklimációs válaszok indukciójában 
Kísérleteinkben ennek az antioxidáns rendszernek a változó fényviszonyokhoz történő akklimációban játszott szerepét vizsgáltuk különböző növényeken (dohány, szőlö, hárs) és üvegházi, mesterségesen megválasztott, illetve természetes fényviszonyok között. Az antioxidánsokat a teljes antioxidáns kapacitások (TAC: Trolox ekvivalens antioxidáns kapacitás, TEAC; vasion-redukáló képesség, FRAP; teljes fenolosvegyület-tartalom, TFT) mérésével jellemeztük, illetve alkalmaztuk a ROS-specifikus antioxidáns kapacitás (SAC) próbák ismert (szuperoxidgyök-kioltás) és laborunkban továbbfejlesztett (hidroxilgyök, szinglett oxigén) változatait is. Elemeztük továbbá az akklimációban az UV-B abszorbeáló pigmentek és karotenoidok szerepét.

Céljaink között szerepelt annak elemzése, hogy ezek az antioxidáns kapacitás próbák mennyire reagálnak érzékenyen a levelek eltérő fiziológiai állapotát kísérő antioxidáns változásokra, illetve hogy milyen összefüggések találhatók a levelek TAC és SAC értékei és természetes (szeneszcencia, kor) illetve mesterséges (a nevelési fényhez képest magasabb fényintenzitás, UV-sugárzás) hatásokra megváltozó fiziológiai állapotuk (fotoszintetikus hatékonyságuk) között.

A változó fényhez való alkalmazkodás vizsgálatakor a UV-sugárzást választottuk akklimációs tényezőként (a fenti okok miatt), és először azt elemeztük, hogy a korukból eredően eltérő antioxidáns-tartalommal rendelkező levelek válaszai üvegházi körülmények között alkalmazott kiegészítő UV-sugárzásra mennyire térnek el. Ezután azt vizsgáltuk, javítható-e a növények UV akklimációs válasza az antioxidáns-tartalom előzetes, célzott megváltoztatásával, amit magas fényen történő elökezeléssel értünk el. Emellett a növényi antioxidánsok egy jól jellemzett, magas fény és UV-indukált csoportjának, a flavonoidoknak a szerepét becsültük fel a természetes napsugárzáshoz történő alkalmazkodásban.

Üvegházban nevelt különböző korú, illetve előkezeléssel stimulált eltérő antioxidáns-tartalmú dohány és szőlő leveleinek elemzésével megállapítottuk, hogy a TAC paraméterek alapvetően érzékenyek és jól követik a természetes folyamatokból, vagy az UV-akklimációs hatásokra válaszul kialakuló fiziológiai változásokat. Vizsgálataink azt mutatták, hogy az adott hatás természetétől függően (szeneszcencia, oxidatív stressz, fényakklimáció) a TAC paraméterek nem egységesen írják le az antioxidáns változásokat, és a méréseket mindig fontos fiziológiai (fotoszintetikus aktivitást mérő) módszerekkel és a specifikus ROS antioxidáns próbákkal kiegészíteni (Majer és mtsai. 2010). A specifikus ROS-kioltásokat mérő próbák válaszai alapján kimutattuk a $\mathrm{O}_{2}{ }^{--}$antioxidánsok szerepét az UV-akklimációban. 
A különböző korú szőlőlevelek UV-akklimációjának vizsgálata során azt állapítottuk meg, hogy a fiatal levelek nagyobb alkalmazkodóképességgel rendelkeznek, melynek alapja antioxidánsaik indukciója volt (Majer és Hideg 2012a). Ezzel szemben az idős leveleket e paraméterek eleve magasabb értékei nem védték meg az UV károsító hatásától.

Az antioxidánsok célzott indukciójára irányuló magas fény előkezelés után is vizsgáltuk az UV-akklimációt (dohányon), és megállapítottuk, hogy a kialakult magasabb antioxidáns kapacitás elősegítette az ezután alkalmazott kiegészítő UV-kezeléshez történő akklimációt Majer és Hideg 2012b). Ez az eredmény lehetséges kereszttolerancia utak szerepét jelezte a látható fény és az UV-fény indukált válaszokban, a növények ezekre adott alkalmazkodási folyamataiban. Ezt a feltételezést megerősítette az a megfigyelésünk is, hogy az UV-B abszorbeáló pigmentek néven ismert csoportot alkotó, jellemzően a fenolos vegyületek közül kikerülö komponensek magas fény hatására is indukálódnak. Ennek hatására irányítottuk figyelmünket a flavonoidok, mint e vegyületek legjelentősebb csoportjának akklimációt elősegítő szerepére.

A természetes fényhez való hosszabb távú alkalmazkodás elemzéséhez a preventív, energia disszipációs utak szerepét is vizsgáltuk néhány napra napfényre helyezett üvegházban nevelkedett dohányoknál, hogy választ kapjunk arra a kérdésre, ilyen körülmények között is jellemző lehet-e ROS válaszok kialakulása. Megállapítottuk, hogy a preventív utak mellett is nagy jelentőségü a napfényhez adaptálódott levelekben a ${ }^{1} \mathrm{O}_{2}$ előfordulása és így, az azt kioltó antioxidánsok mennyiségének növekedése (Hideg és Majer 2010). A természetes napfényben fejlődő hárs fény- és árnyékleveleinek flavonoidtartalmát ennek a a ${ }^{1} \mathrm{O}_{2}$ antioxidáns képességének függvényében elemezve a flavonoidtartalom jelentős növekedését és specifikus megváltozását figyelhettük meg a napon nőtt leveleknél (megnövekedett kvercetin:kaempferol arány, miricetin felhalmozódása). A flavonoidok antioxidáns kapacitásának és abszorbciós spektrumának in vitro elemzése együttesen arra a következtetésre vezetett, hogy szerepük a fényakklimáció során inkább fotoinhibíció elleni antioxidáns vegyületként, mint UV-B abszorbeáló pigmentként jelentős (Majer és mtsai. 2013). 


\section{SUMMARY}

Plants have a high adaptive potential to acclimate to different light regimes, that involves the protection against the potential hazardous effects of high photosynthetically active radiation (PAR) and ultraviolet (UV) radiation reaching the Earth's surface (290-400 nm). Although these sunlight components are essential or beneficial for the development and life of plants as energy (PAR) or information source (PAR and UV), these can manifest as oxidative stressors. Acclimation processes are aiming at avoiding these harmful effects by maintaining the prooxidant-antioxidant balance. High PAR intensities can lead to the lightinduced inhibition of photosynthesis, photoinhibition, a process characterized by the accumulation of reactive oxygen species (ROS). ROS (superoxide anion, $\mathrm{O}_{2}{ }^{\circ}$; hydrogene peroxide, $\mathrm{H}_{2} \mathrm{O}_{2}$; hydroxyl radical, ${ }^{\circ} \mathrm{OH}$; singlet oxygen, ${ }^{1} \mathrm{O}_{2}$ ) are potentially harmful agents, that can generate other reactive radical or non-radical species in a chain reaction, leading to the degradation of cell components, lipid peroxidation and by provoking oxidative stress, finally to cell death. Elevated ROS production is characteristic to changes in other factors of the abiotic environment as well, that require the rearrangement of energy sources, thereby enhancing photoinhibition. However, plants are equipped with efficient mechanisms for preventing ROS formation or scavenging these species. The former is mainly achieved by energy dissipation, while the latter is realized through the action of the antioxidant system, comprising of a co-operative, multilevel system of enzymes and nonenzymatic compounds. Indeed the balance between prooxidants (including ROS and derived reactive substances) and antioxidants, i.e. the effort of maintening the redox homeostasis of cells, is the key factor in acclimatory response to environmental cues. Stressors directly or indirectly (mostly through hormone signalling pathways) or ROS itself can induce antioxidative defense responses, thereby promoting the installation of a new balance leading to acclimation to the changing environment. High UV-B doses lead to detectable levels of ROS production and oxidative stress, while lower, chronic levels may be involved in the induction of acclimatory pathways presumably mediated by lower ROS concentrations.

In our experiments we were aiming at elucidating the role of this antioxidant system in the acclimation of different plants (tobacco, grapevine, linden) to changing light environment in artificially adjusted green-house or naturally occurring light conditions. The antioxidants were characterized by total antioxidant capacities (TAC), like TEAC 
(Trolox equivalent antioxidant capacity), FRAP (ferric reducing antioxidant power) and TPC (total phenolics content), and by ROS-specific antioxidant capacities (SAC), including the widely used test for superoxide dismutase activity, and newly developed ones for hydroxyl radical and singlet oxygen scavenging. We analysed the role of UV-B absorbing compounds and carotenoids in the acclimation processes as well.

We were aiming at testing the sensitivity of the antioxidant capacity assays to the antioxidant changes accompanying the various physiological conditions of leaves, and the exploration of correlations between the TAC and SAC parameters of leaves in response to natural (senescence, age) or artificially (high light, UV-radiation) induced changes in their physiological state (photosynhetic efficiency).

UV-radiation was chosen as the abiotic acclimation factor (for the above reasons), and first we studied how the responses of leaves at different ages with different antioxidant contents vary for supplementary UV-radiation in a green-house experiment. Thereafter, we investigated whether the UV-acclimation potential of leaves can be aided by stimulating the antioxidant content by a high light pretreatment prior to the UV treatment. Furthermore, we studied the role of flavonoids, a well-characterized group of plant antioxidants that were shown to be induced both by high light and UV, in the acclimation to natural sunlight.

By studying leaves of tobacco and grapevine with different antioxidant capacities due to their age or to stimulation by pretreatment in green-house experiments, we concluded that TAC parameters are sensitive enough to follow the physiological changes deriving from developmental stage or altered in the UV-acclimation process. However, our studies proved that based on the nature of the effect (senescence, oxidative stress, light acclimation), TAC parameters do not describe antioxidant status uniformly, therefore these assays should always be complemented with physiological (photosynthetic) measurements and tests exploring ROS specific antioxidants (Majer et al. 2010). For example, based on the responsiveness of SAC assays we could gain evidences on the role of $\mathrm{O}_{2}{ }^{--}$antioxidants in UV-acclimation.

Monitoring the UV-acclimation of grapevine leaves of different age lead us to the conclusion that younger leaves have a greater ability to adapt to UV and that this is based on the induction of antioxidants in these leaves in response to UV (Majer and Hideg 2012a). In contrary, old leaves were not protected from the damaging effects of UV by their originally higher capacities. 
We studied UV-acclimation potential of (tobacco) plants following an antioxidantstimulating high light pretreatment, and concluded that the higher antioxidant capacities of these plants supported their acclimation to the UV-radiation applied subsequently (Majer and Hideg 2012b). This result indicated the existence of potential cross-tolerance pathways between visible and UV-light induced acclimatory responses. This assumption was further supported by our observation, that the components of the group generally referred to as UV-B absorbing pigments, that are mainly phenolic compounds, are induced by high light as well. Therefore we directed our attention to the dissection of the role of flavonoids, the most outstanding group of phenolics, in acclimation to light.

In longer-term acclimation to natural sunlight irradiances, we studied the role of preventive, energy dissipation pathways on tobacco plants grown in green-house and placed outdoors under sunlight for a few days, to see whether ROS-mediated responses play a role under these conditions. We stated that in acclimation to sunlight, besides preventive pathways, the occurence of ${ }^{1} \mathrm{O}_{2}$ and therefore its antioxidants can be significant (Hideg és Majer 2010). By dissecting the flavonoid content of natural grown sun and shade linden leaves with the aspect of the ${ }^{1} \mathrm{O}_{2}$ antioxidant capacity, we could observe a significant increase and a specific shift in flavonoid content of sun leaves (increased quercetin:kaempferol ratio, accumulation of myricetin). The in vitro analysis of the antioxidant capacity and the absorption spectra of flavonoids together lead to the conclusion that their role in light acclimation is rather based on their antioxidant activity, than their screening efficiency as a UV-B absorbing compound (Majer és mtsai. 2013). 


\section{KÖSZÖNETNYILVÁNÍTÁS}

Elsősorban témavezetőmnek, Dr. Hideg Évának köszönöm meg, hogy idejével, türelmével, tapasztalatával és figyelmességével megajándékozott, miközben a munkámat elmélyült szakmai tudásával, kreativitásával felügyelte, sok szabadságot hagyva nekem benne, hogy kiválaszthassam a számomra érdekes aspektusokat.

Hasonlóan köszönettel tartozom Dr. Horváth V. Gábornak, akinek a csoportjában a munkám megkezdtem, s akitől szintén sokat tanulhattam szakmai fegyelme, iránymutatása és logikus gondolkodása révén.

Mindkét csoportom, a Molekuláris Stressz- és Fotobiológiai Csoport és a Növényi Sejtosztódási és Stressz Adaptációs Csoport minden volt és jelenlegi tagjának hálás vagyok a sok segítségért, jó társaságért, a hétfő reggeli mosolyokért és hogy mindig volt egy kedves szavuk vagy egy szelet csokijuk, hogy felderítsenek.

Külön köszönettel tartozom Dr. Vass Imrének, csoportvezetőmnek, s egyben a Növénybiológia Intézet igazgatójának, amiért lehetőséget biztosított a munkavégzésre és szakmai elhivatottságával állandó példát mutat nekem.

Köszönetet mondok az SZBK doktorandusz kutatói ösztöndíjaért is, amiben részesültem 2009 és 2011 között (és itt jár Artúrnak egy köszönet, amiért annak idején támogatta a jelentkezésem), és persze a SZTE Biológiai Doktori Iskolájának, amiért biztosították a képzést. Az egész Kutatóközpont annak minden facilitásával és dolgozójával támogatta az itteni munkámat, és külön köszönet jár a Biokémia Intézet Membrán- és Stresszbiológiai Egységének, hogy lehetővé tették számomra a spektrofluoriméterük használatát.

Előző munkaadómnak, Dr. Pauk Jánosnak is hálás vagyok, amiért alkalmazott a csoportjában, a Gabonakutató Nonprofit Kft. Biotechnológia Osztályán, ezzel elindítva tudományos pályafutásomat. Az ottani csoportom minden tagjának is köszönöm, hogy oly gyorsan befogadtak és segítettek elindítani a pályám, s a mai napig is jó viszonyt ápolnak velem. 
A 2010 júniusa óta tartó COST együttmüködés (COST Action FA0906 - UV-B radiation: A specific Regulator of Plant Growth and Food Quality in a Changing Climate) nagyban támogatta munkámat konferenciákon való részvétel és kooperációk elősegítésével, illetve nyári iskolákon, módszertani kurzusokon való részvételi lehetőségekkel. Ezért többek között Dr. Marcel A. K. Jansen-nek, a projekt koordinátorának is szeretném hálámat kifejezni. Dr. Andreas Albertnek, aki szintén az együttmőködés keretein belül látogatott el hozzánk, köszönöm az UV spektrális irradiancia méréseket. A COST keretein belül valósult meg két hetes németországi tanulmányutam is Dr. Monika Schreiner kutatócsoportjában (IGZ Großbeeren, Németország), amit ezúton köszönök meg neki és kollégáinak.

A PhD képzésem ideje alatt támogatást kaptam még a Scientia Amabilis Alapítvány a Magyar Növényélettanért szervezettöl (elnök Dr. Szigeti Zoltán) egyszeri ösztöndíj formájában, illetve SZTE Talent Ösztöndíjban is részesültem, amiket ezúton köszönök meg.

Köszönöm Dr. Janda Tibornak, hogy rövid határidővel vállalta a disszertációm átolvasását és az opponensi szerepet a házi védésemen.

A családomtól mindvégig erős támogatást kaptam, nélkülük nem lehetnék az, aki vagyok, és ott, ahol vagyok - köszönöm, hogy elengedtetek és hagyjátok, hogy az utamat járjam, miközben mindig szeretettel vártok haza!

Egy külön köszönet jár Nándinak, aki felnyitotta a szemem a tudomány csodáira. Minden barátomnak, ismerősömnek köszönöm a beszélgetéseket és a fontos pillanatokat.

És végül - de igazán nem utolsó sorban - szeretném megköszönni ezeknek a csodálatos fotoszintetizáló szervezeteknek, hogy szépen nőttek nekem, lehetővé téve, hogy tanulmányozzam izgalmas életüket. 